\author{
Universidade de São Paulo \\ Faculdade de Ciências Farmacêuticas de Ribeirão Preto
}

Estudo do efeito de respostas de hipersensibilidade sobre a parede celular em cultura de células de amora-preta (Rubus fruticosus)

Fernando Aparecido Mariano de Souza

Ribeirão Preto 
Fernando Aparecido Mariano de Souza

\section{Estudo do efeito de respostas de hipersensibilidade sobre a parede celular em cultura de células de amora-preta (Rubus fruticosus)}

Dissertação de Mestrado apresentada ao Programa de Pós-Graduação em Ciências Farmacêuticas da Faculdade de Ciências Farmacêuticas de Ribeirão Preto, Universidade de São Paulo, para a obtenção do título de Mestre em Ciências Farmacêuticas.

Área de Concentração: Produtos Naturais e Sintéticos.

Orientadora: Profa. Dra. Carem Gledes Vargas-Rechia

Ribeirão Preto 


\section{AUTORIZO A REPRODUÇÃO E DIVULGAÇÃO TOTAL OU PARCIAL DESTE TRABALHO, POR QUALQUER MEIO CONVENCIONAL OU ELETRÔNICO, PARA FINS DE ESTUDO E PESQUISA, DESDE QUE CITADA A FONTE.}

\section{FICHA CATALOGRÁFICA}

de Souza, Fernando Aparecido Mariano

Estudo do efeito de respostas de hipersensibilidade sobre a parede celular em cultura de células de amora-preta (Rubus fruticosus). Ribeirão Preto, 2007.

145p.; il.; $30 \mathrm{~cm}$

Dissertação de Mestrado apresentada ao Programa de PósGraduação em Ciências Farmacêuticas (Área de Concentração: Produtos Naturais e Sintéticos) da Faculdade de Ciências Farmacêuticas de Ribeirão Preto/USP.

Orientadora: Profa. Dra. Carem Gledes Vargas-Rechia.

1. respostas de hipersensibilidade. 2. espécies reativas de oxigênio 3. elicitor. 4. ácido salićlico. 5. ramnoglucoronogalactana. 6. metil jasmonato. 7. cultura de células. 8. Rubus fruticosus. 9. parede celular. 


\section{Folha de Aprovação}

AUTOR: Fernando Aparecido Mariano de Souza

TíTULO: Estudo do efeito de respostas de hipersensibilidade sobre a parede celular em cultura de células de amora-preta (Rubus fruticosus).

Dissertação de Mestrado apresentada ao Programa de Pós-Graduação em Ciências Farmacêuticas da Faculdade de Ciências Farmacêuticas de Ribeirão Preto, Universidade de São Paulo, para a obtenção do título de Mestre em Ciências Farmacêuticas.

Área de Concentração: Produtos Naturais e Sintéticos.

\section{Comissão Examinadora}

$\operatorname{Prof}(\mathrm{a}) \cdot \operatorname{Dr}(\mathrm{a}) .:$

Instituição: Assinatura:

$\operatorname{Prof}(\mathrm{a}) . \operatorname{Dr}(\mathrm{a})$. :

Instituição:

Assinatura:

$\operatorname{Prof}(\mathrm{a}) . \operatorname{Dr}(\mathrm{a})$.:

Instituição:

Assinatura:

Trabalho defendido e aprovado pela Comissão Julgadora em $. / \ldots \ldots . . . . . \ldots \ldots . . .$. 
"O ser humano vivencia a si mesmo, seus pensamentos, como algo separado do resto do universo, em uma espécie de ilusão de ótica da sua consciência. E essa ilusão é um tipo de prisão que nos restringe a nossos desejos pessoais, conceitos e ao afeto apenas pelas pessoas mais próximas.

Nossa principal tarefa é a de nos livrarmos dessa prisão, ampliando o nosso círculo de compaixão, para que ele abranja todos os seres vivos e toda a natureza em sua beleza.

Ninguém conseguirá atingir completamente este objetivo, mas lutar pela sua realização já é por si só parte de nossa liberação e o alicerce de nossa segurança interior."

Albert Einstein 
DEDICATÓRIA 
Ofereço este trabalho a Deus, e a Jesus Cristo seu Filho, que estão sempre presentes em todas as etapas de minha vida, manifestando-se com suas presenças de muitas maneiras, nos momentos bons e ruins. Obrigado Senhor, por tudo o que tem feito por mim até hoje... Agradeço de todo o coração! 
Dedico este trabalho à minha família, a razão da minha existência. Ao meu pai, Lázaro, que é a pessoa mais bem resolvida com Deus, o meu ídolo e que me ensinou o verdadeiro valor de ser o amigo de alguém. A minha Mãe, Mafalda, que me mostrou o que é amor incondicional e que é o meu exemplo de honestidade e bondade. Ao meu amigão e irmão Lázaro Júnior que, mesmo sendo meu irmão mais novo, é o meu exemplo, e pela amizade, companheirismo e dedicação. Ao meu irmão Sílvio, pelo incentivo, ensinamento e consideração. Não tenho palavra pra vocês!

Muito Obrigado! 
A Profa. Dra. Carem Gledes Vargas-Rechia, pela compreensão, paciência e generosidade para comigo, por ter a oportunidade de trabalhar com uma linha de pesquisa tão abrangente que faz uso de metodologias consagradas, más envolvendo perguntas importante que contribuem para o conhecimento científico e desenvolvimento tecnológico do país, e pela chance ser um dos primeiros, dentre os muitos que ainda estão por vir, alunos de pós-graduação sob a sua orientação!

Muito obrigado! 
AGRADECIMENTOS 


\section{Agradecimentos}

Ao meu amigo Wagner Rodrigo de Souza, pela amizade, ajuda tanto na parte da pesquisa quanto fora dela também, uma pessoa capaz de fazer o possível e o impossível em prol dos amigos que estima. Pelas confissões, muitas gargalhadas, amigos em comum, valeu Zé!

Ao Seu Alcides Silva Pereira, pela amizade, pela grande competência, pelos ensinamentos de vida e de trabalho, de muita humildade, de respeito ao próximo, pelos assuntos descontraídos, boas risadas e conversas no Silvão.

Á Dona Nadir Mazzucato, pela amizade, pela competência, boas risadas, preocupação conosco do laboratório, pela grandeza da sua simplicidade, fazendo sempre uma brincadeira, pelas ajudas no laboratório.

Aos meus amigos Mateus Freire Leite, Laura Martins e Jennifer Michiko Chauca Yokoya, pelas amizades sinceras, boas conversas, ajudando uns aos outros nas disciplinas da vida, e nós sabemos as dificuldades que existem!

Á leda Maria Razaboni Prado, pela competência, discernimento, experiência na vida e na pesquisa.

À Maria Regina de Pila Raphaloski, pela amizade, incansável dedicação, pela atenção, competência e respeito.

À Ana Cristina Morseli Polizello, pela amizade, grande carinho e atenção com todos, pela competência e dedicação. 
Ána Elisa Caleiros Seixas Azzolini, pela grande dedicação, pela competência, e atenção para com todos.

Às funcionárias da Seção de Pós-Graduação, Rosana Ferreira L.S. Florêncio, Ana Lúcia Turatti, Eleni Angeli Passos, que sempre foram muito atenciosas comigo e que me ajudaram até em momentos que não tinham a obrigação, obrigado!

Aos Profs. Drs. do Laboratório de Bioquímica, à Ana Isabel de Assis Pandochi, pelo gosto à pesquisa e ao ensino, Carlos Curti, pela simplicidade e gosto à ciência, Augusto César Cropanese Spadaro, pela amizade e dedicação ao ensino, à Yara Maria Lucisano Valim, pelo amor ao ensino e pela atenção para com todos.

Aos estimados amigos Pós-graduandos do Laboratório, Anaísa Fernandes Calgaro Helena, Fabiana da Silva Paula, Daniel Junqueira Dorta, Cezar Rangel Pestana, Luciana Mariko Kabeia, Cássio de Barros Pontes, Alexandre Kanashiho, Daiani Cristina Oliveira Andrade, Cláudia da Silva Bittencourt, Denise Pimenta da Silva Leitão, Cleni Mara Marzocchi-Machado, valeu pelas amizades, pelas lições de dedicação, perseverança, força, inteligência, atitude, coragem, humildade e competência, mesmo para aqueles que saíram do nosso convívio, felicidades e sucesso!

Aos estimados amigos estagiários da Bioquímica, Joel Gonçalves de Souza, Andréa Silva Garcia de Figueiredo, Helga Namie Ferreira Murakami, João Paulo de Mello, Cláudia Meireles, Daniela Paula dos Santos Phelippin, pelas amizades, conversa e boas risadas, muitas felicidades pra vocês! 
Aos novos integrantes do nosso grupo de pesquisa, Roberta de Mello, Viviane Cristina Guimiero, José Franciraldo de Lima, pela amizade e consideração, e pela torcida que tenho pelo sucesso de vocês ai no laboratório, precisando é só falar.

Á estimada segunda família que eu tive o privilégio de ganhar desde o meu nascimento, a Dona Maria Rosa dos Santos Ribeiro (a Nê) que é a minha mãe-preta, a Maria Regina dos Santos Ribeiro (a Rê), a filha da Nê que eu considero como minha irmã e ao Manuel Ribeiro (o Seu Mané), o patriarca desta família linda que eu tenho a graça de Deus fazer parte também, pra vocês eu vou sempre dedicar parte das minhas orações...

Aos irmãos Carlos Alessandro Fuzo e Cristiano Ricardo Del Lama, pelas amizades, lições de caráter, de honestidade, conduta e consideração, muitas felicidades pra vocês manos!

Aos grandes amigos Alexandre Massaro Onusic, Adriano Olian Cssano, Vitor Barusco, Fabio Venning, Daniédison Oliveira, essa turma que consolidou valores na minha formação como pessoa, muito obrigado!

À estimadíssima super família do apartamento A1 da Moradia da USP CREU, pelas amizades sinceras, e alegrias que me proporcionaram, e que me fizeram ter duas formaturas: a minha da Farmácia e a nossa da Química, Jorge, Neila, Miguel, Cleyton, Edna, Marquinhos, Fernanda, Fernando Primo, Fernando Carmona, Santones, Márcia, André, Evandro, Antônio Ricardo, Rose, Janaína, obrigado por vocês terem feito parte da melhor época das nossas vidas, por ajudarem a construir a minha personalidade, muitas felicidades pra todos vocês! 
A minha grande família espalhada por todos os cantos deste interior paulista, Lucilha, Nelson, Anderson, Flavia, Francini, Renata, Daniel, Adriana, Júlio, Maurinho, Maria Luiza, Zé Jão, Geni, Aline, Gilberto, Rodolfo Rita, Fabiano Maranhão, Lílian da Costa Castro, Daiane Batistão, Vanessa Landau, Fernanda Mishima, Tânia, Murilo, Renan, Marianinha, Lívia, Ciça, Rita, Fernanda Pazzeto, Marquim, desculpem-me se esqueci de alguém...

À Profa. Dra. Fany Reicher e a sua linha de pesquisa do Laboratório de Carboidratos Vegetais da UFPR, pelos estudos que ajudaram a idealizar este projeto.

Ao Prof. Dr. Richard John Ward, pela boa vontade de permitir o uso do seu laboratório e em particular a sua aluna Tatiana Lopes.

Ao Prof. Dr. Antônio Cláudio Tedesco, pela boa vontade dos seus alunos e meus amigos Fernando Primo, Cris e Jean Cláudio Balan, mostrando que uma simples conversa de amigo pode resolver um problema experimental.

A Fundação de Amparo a Pesquisa do Estado de São Paulo (FAPESP), pelo incentivo à pesquisa e pelo apoio aos estudantes, valorizando a contribuição que eles fornecem aos avanços científicos e tecnológicos do estado e do país.

A todos que, direta ou indiretamente, tenham participado da realização deste trabalho, desculpem-me novamente se esqueci alguém. 
RESUMO 


\section{DE SOUZA, F.A.M. Estudo do efeito de respostas de hipersensibilidade}

sobre a parede celular em cultura de células de amora-preta (Rubus fruticosus). 2007. 145f. Dissertação (Mestrado) - Faculdade de Ciências Farmacêuticas de Ribeirão Preto, Universidade de São Paulo, Ribeirão Preto, 2007.

Como os outros organismos, as plantas têm a habilidade de se defenderem através do reconhecimento de patógenos (resposta de hipersensibilidade - $\mathrm{RH}$ ), causando a morte imediata das células no sítio primário da infecção, desta maneira oferecendo resistência ao seu crescimento. A RH é caracterizada pela necrose dos tecidos neste local, através de muitos sinais ainda não completamente elucidados, como a formação de radicais livres, incluindo o peróxido de hidrogênio $\left(\mathrm{H}_{2} \mathrm{O}_{2}\right)$, e o reforço da parede celular. $\mathrm{O}$ objetivo deste estudo foi estabelecer a relação entre esses sinais em cultura de células de amora-preta (Rubus fruticosus). As condições experimentais para a análise da parede celular, das espécies reativas de oxigênio (EROs) e do $\mathrm{H}_{2} \mathrm{O}_{2}$ foram padronizadas. O polissacarídeo ácido (ramnoglucuronogalactana, F-I), o ácido salicílico (AS), e o metil jasmonato (MeJA), bem estabelecidos efetores da resposta da defesa, foram usados como elicitores. A produção das EROs e do $\mathrm{H}_{2} \mathrm{O}_{2}$ foram ativadas por $\mathrm{F}-\mathrm{I}$ e pelo $\mathrm{AS}$, seguidos da liberação de fragmentos de dissacarídeos da parede celular, aparentemente devido a sua degradação. Por outro lado, uma produção pequena de EROs e de $\mathrm{H}_{2} \mathrm{O}_{2}$ foram observadas na presença de MeJA, assim como um aumento de fragmentos de massa molecular mais elevada, que podem funcionar como sinais para o reforço da parede celular, indução de enzimas e para a produção de outra moléculas de defesa. Quando da 
elicitação, concomitante, com dois elicitores, AS + MeJA, houve a inibição da produção de EROs causada pelo MeJA e foi mantida a liberação de compostos extracelulares de massa molecular mais elevada.

Palavras-chave: ramnoglucuronogalactana, ácido salicílico, metil jasmonato, EROs, $\mathrm{H}_{2} \mathrm{O}_{2}$, resposta de hipersensibilidade, Rubus fruticosus, parede celular, elicitores. 
ABSTRACT 
DE SOUZA, F.A.M. Study of the effects of hypersensitive response on cell wall in blackberry-black cell culture (Rubus fruticosus). 2007. $145 f$. (Master's degree) - Faculdade de Ciências Farmacêuticas de Ribeirão Preto, Universidade de São Paulo, Ribeirão Preto, 2007.

Like the other organisms, plants have the ability to self-defend through recognition of pathogens (hypersensitive response - HR), causing immediate cell death at the primary infection site, thus offering resistance to their grown. The HR is characterized by necrosis of tissues in this site via many signals still not completely elucidated, like formation of free radicals including $\mathrm{H}_{2} \mathrm{O}_{2}$ and reinforcement of cell wall. The aim of this study was to establish the relationship between these signals in blackberry-black cell culture (Rubus fruticosus). The experimental conditions for analysis of cell wall, reactive oxygen species (ROS) and $\mathrm{H}_{2} \mathrm{O}_{2}$, were established. Acid polysaccharide (rhamnoglucuronogalactan, $\mathrm{F}-\mathrm{I}$ ), salicylic acid (SA), and methyl jasmonate (MeJA), well established effectors of the defense response, were used as elicitors. ROS and $\mathrm{H}_{2} \mathrm{O}_{2}$ production was activated by F-I and SA, followed by release of fragments like disaccharides from the cell wall, apparently due to its degradation. By contrast, a small production of ROS and $\mathrm{H}_{2} \mathrm{O}_{2}$ was observed in presence of MeJA, as well as an increase of high molecular weight fragments, that may function as signals for reinforcement of cell wall, enzyme induction and production of others defense molecules. Together, the two elicitors SA and MeJA inhibited the ROS production, caused by MeJA, while sustaining release of the extra cellular compounds of high molecular weight.

Keywords: rhamnoglucuronogalactan, salicylic acid, methyl jasmonate, ROS, $\mathrm{H}_{2} \mathrm{O}_{2}$, hypersensitive response, Rubus fruticosus, cell wall, elicitors. 


\section{LISTA DE SIGLAS E ABREVIATURAS}




\begin{tabular}{|c|c|}
\hline $2,4-D$ & ácido 2, 4-diclorofenoxiacético \\
\hline${ }^{1} \mathrm{O}_{2}$ & oxigênio singleto \\
\hline AJ & ácido jasmônico \\
\hline ANOVA & análise da variância \\
\hline APX & ascorbato peroxidase [EC 1.11.1.11] \\
\hline AS & ácido salicílico \\
\hline ATP & adenosina - 5' - trifosfato \\
\hline avr & avirulência \\
\hline $\mathrm{BA} 2 \mathrm{H}$ & ácido benzóico 2-hidroxilase [EC 1.14.13.12] \\
\hline BSA & albumina de soro bovino \\
\hline CASLP1 & clone de cDNA codificador de Stellacyanin \\
\hline CAT & catalase [EC 1.11.1.6] \\
\hline CLAE & cromatografia líquida de alta eficiência \\
\hline DMSO & dimetilsulfóxido \\
\hline EGTA & ácido bis(2-aminoetil) etilenoglicol-N,N,N',N'-tetraacético \\
\hline ELISA & Enzyme Linked Immuno Sorbent Assay (ensaio enzimático) \\
\hline EROs & espécies reativas de oxigênio \\
\hline ET & etileno \\
\hline $\mathrm{F}-\mathrm{I}$ & $\begin{array}{l}\text { ramnoglucuronogalactana extraída do tegumento das sementes de } \\
\text { paineira }\end{array}$ \\
\hline GLC & cromatografia líquido-gasosa \\
\hline GP & grau de polimerização \\
\hline GSH & glutationa reduzida \\
\hline $\mathrm{H}_{2} \mathrm{DCF}-\mathrm{DA}$ & diacetato de 2,7-diclorofluoresceina \\
\hline $\mathrm{H}_{2} \mathrm{O}_{2}$ & peróxido de hidrogênio \\
\hline HRP & peroxidase de rabanete [EC 1.11.1.7] \\
\hline HVA & ácido homovanílico \\
\hline ICS1 & isocorismato sintase 1 [EC 5.4.4.2] \\
\hline IPL1 & isocorismato piruvato liase 1 [EC 4.1.99.-] \\
\hline LOX & lipoxigenase [EC 1.13.1.13] \\
\hline UV & ultravioleta \\
\hline MAPK & proteína quinase mitógeno-ativada [EC 2.7.11.24] \\
\hline MAPKK & proteína quinase-quinase mitógeno-ativada [EC 2.7.12.2] \\
\hline MAPKKK & proteína quinase-quinase-quinase mitógeno-ativada [EC 2.7.11.25] \\
\hline MDTP & $\begin{array}{l}\mathrm{M}=\text { monossacarídeo de glucose } \mathrm{D}=\text { dissacarídeo de maltose } \\
\mathrm{T}=\text { tetrassacarídeo de glucose e } \mathrm{P}=\text { pentassacarídeo de glucose }\end{array}$ \\
\hline
\end{tabular}




$\begin{array}{ll}\text { MeJA } & \text { metil jasmonato } \\ \text { MSC } & \text { meio de suspensão celular } \\ \text { NADPH oxidase } & \text { nicotinamida adenina dinucleotídeo fosfato-oxidase [EC 1.6.3.1] } \\ \text { NO } & \text { óxido nítrico } \\ \mathrm{O}_{2}{ }^{-} & \text {radical superóxido } \\ \mathrm{O}_{3} & \text { ozônio } \\ \mathrm{OGAs} & \text { oligogalacturonídeos } \\ \mathrm{OH} & \text { radical hidroxila } \\ \mathrm{PAL} & \text { fenil alanina amônia liase [EC 4.3.1.5] } \\ \mathrm{PCD} & \text { morte celular programada } \\ \mathrm{PGA} & \text { ácido poli-galacturônico } \\ \mathrm{PLA2} & \text { fosfolipase A2 [EC 3.1.1.4] } \\ \mathrm{POD} & \text { Peroxidase [EC 1.11.1.7] } \\ \text { proteína-RP } & \text { proteína relaciona à patogênese } \\ \mathrm{R} & \text { resistência } \\ \mathrm{RG}-\mathrm{I} & \text { ramnogalacturonana do tipo I de parede celular primária } \\ \mathrm{RH} & \text { resposta de hipersensibilidade } \\ \mathrm{RSA} & \text { resistência sistêmica adquirida } \\ \mathrm{RSI} & \text { resistência sistêmica induzida } \\ \mathrm{SOD} & \text { superóxido dismutase [EC 1.15..1.1] } \\ \text { Tris } & \text { tris-hidroximetil aminometano } \\ \text { URF } & \text { unidades relativas à fluorescência } \\ \text { XXLGol } & \end{array}$




\section{LISTA DE TABELAS}


Tabela 1 - Quantidades de macro e microelementos utilizados para preparação do meio de cultura de Rubus fruticosus...

Tabela 2 - Açúcares extracelulares liberados em elicitações com AS, F-I e MeJA.

Tabela 3 - Açúcares extracelulares liberados em elicitações com F-I + AS, $\mathrm{F}-\mathrm{I}+\mathrm{MeJA}$ e AS + MeJA.

Tabela 4 - Massa de parede celular obtida após os ensaios de elicitação com os elicitores.

Tabela 5 - Massa de parede celular obtida após os ensaios de elicitação com as misturas de elicitores.. 


\section{LISTA DE FIGURAS}


Figura 1. Envolvimento das EROs em processos metabólicos de resposta das plantas a vários estresses ambientais......

Figura 2. Fluxo de elétrons durante o 'burst' oxidativo: espécies reativas de oxigênio (EROs) derivadas do $\mathrm{O}_{2}$, via de detoxificação (limpeza) e inter-conversões em plantas.

Figura 3. Fases da produção de EROs na interação planta-bactéria.

Figura 4. Modelo de parede celular primária do tipo I...

Figura 5. Modelo de parede celular primária do tipo II.

Figura 6. Via metabólica do corismato......

Figura 7. Via metabólica dos fenilpropanóides.

Figura 8. Via sinalizadora para a síntese do ácido jasmônico.

Figura 9. Fluxograma do protocolo experimental para os ensaios de elicitação com F-I, MeJA, AS e suas misturas.

Figura 10. Estudos de incubação com o $\mathrm{H}_{2}$ DCF-DA em resposta a liberação de EROs em células de Rubus fruticosus.

Figura 11. Estudos de elicitações prévias em resposta a liberação de EROs em células de $R$. fruticosus.

Figura 12. Produção de EROs em diferentes concentrações de F-I, AS e MeJA em células de $R$. fruticosus de 18 dias. Elicitores: A) AS; B) F-I e C) MeJA.

Figura 13. Fluxograma do protocolo experimental para os ensaios de elicitação com F-I, AS, MeJA, e misturas de elicitores, para a determinação da produção de EROs (A) e para a determinação da produção de $\mathrm{H}_{2} \mathrm{O}_{2} \quad$ (B), em células de 18 dias de R. fruticosus.

Figura 14. Resposta de liberação de EROs de cultura de células de Rubus fruticosus em função do tempo de elicitação com os elicitores AS, F-I e MeJA (A); Porcentagem (\%) de fluorescência em relação ao controle em resposta a liberação de EROs de cultura de células de R. fruticosus de 18 dias, com os elicitores AS, F-I e MeJA, em função do tempo de elicitação (B). 
Figura 15. Resposta de liberação de EROs de cultura de células ( $8 \times 10^{4}$ cél. $\left./ \mathrm{mL}\right)$ de $R$. fruticosus de 18 dias com: (A) 15 minutos, (B) 30 minutos, (C) 45 minutos e (D) 60 minutos de elicitação, em

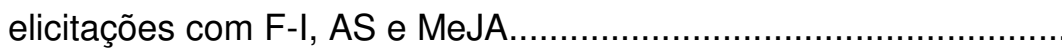

Figura 16. Resposta de liberação de EROs em cultura de células de Rubus fruticosus em função do tempo de elicitação com $\mathrm{F}-\mathrm{I}$ + MeJA, AS + MeJA e F-I + AS (A); Porcentagem (\%) de fluorescência em relação ao controle em resposta a liberação de EROs de cultura de células de $R$. fruticosus de 18 dias, com os elicitores F-I + AS; F-I + MeJA e AS + MeJA, em função do tempo de elicitação (B)

Figura 17. Resposta de liberação de EROs de cultura de células (8 x $10^{4}$ cél. $/ \mathrm{mL}$ ) de $R$. fruticosus de 18 dias com: (A) 15, (B) 30, (C) 45 e (D) 60 minutos de elicitação, em elicitações com F-I + AS, $\mathrm{F}-\mathrm{I}+\mathrm{MeJA}$ e AS + MeJA

Figura 18. Razão entre as curvas de fluorescência do HVA das amostras elicitadas com F-I, AS e MeJA pelo controle, em resposta a liberação de $\mathrm{H}_{2} \mathrm{O}_{2}$ de cultura de células de Rubus fruticosus, em 30 minutos de elicitação (A); Porcentagem (\%) de fluorescência das amostras elicitadas em relação ao controle em resposta a liberação de $\mathrm{H}_{2} \mathrm{O}_{2}$ de cultura de células de $R$. fruticosus de 18 dias, com os elicitores AS, F-I e MeJA, em 30 minutos de elicitação (B).

Figura 19. Fluorescência do HVA em resposta a liberação de $\mathrm{H}_{2} \mathrm{O}_{2}$ de cultura de $R$. fruticosus com 30 minutos de elicitação, em elicitações com F-I, AS e MeJA.

Figura 20. Razão entre as curvas de fluorescência do HVA das amostras elicitadas com F-I +AS, F-I + MeJA e AS + MeJA pelo controle em resposta a liberação de $\mathrm{H}_{2} \mathrm{O}_{2}$, de cultura de células de Rubus fruticosus, em 30 minutos de elicitação (A); Porcentagem (\%) de fluorescência em relação ao controle em resposta a liberação de $\mathrm{H}_{2} \mathrm{O}_{2}$ de cultura de células de $R$. fruticosus de 18 dias, com os elicitores $\mathrm{F}-\mathrm{I}+\mathrm{AS}, \mathrm{F}-\mathrm{I}+\mathrm{MeJA}$ e AS + MeJA, em 30 minutos de elicitação (B). 
Figura 21. Fluorescência do HVA em resposta a liberação de $\mathrm{H}_{2} \mathrm{O}_{2}$ de cultura de $R$. fruticosus com 30 minutos de elicitação, em elicitações com $\mathrm{F}-\mathrm{I}+\mathrm{AS}, \mathrm{F}-\mathrm{I}+\mathrm{MeJA}, \mathrm{AS}+\mathrm{MeJA}$.

Figura 22. Cromatografia em camada delgada (CCD) para avaliar o perfil de açúcar em uma amostra elicitada com F-I

Figura 23. Cromatografia em camada delgada (CCD) para avaliar o perfil de açúcar em uma amostra elicitada com AS

Figura 24. Porcentagem (\%) de açúcar redutor das amostras elicitadas com F-I, AS e MeJA em relação ao controle da fração sobrenadante (fração S) de ensaios de elicitação com tempo de elicitação de 60 minutos.

Figura 25. Teor de açúcar redutor em cultura de células de $R$. fruticosus com 60 minutos de elicitação; células de 18 dias, $8 \times 10^{4}$ cél. $/ \mathrm{mL}$ em $25 \mathrm{~mL}$ de amostra; F-I, AS e MeJA [1000 nmol/L].

Figura 26. Porcentagem (\%) de açúcar redutor das amostras elicitadas com $\mathrm{F}-\mathrm{I}+\mathrm{AS}, \mathrm{F}-\mathrm{I}+\mathrm{MeJA}$ e AS + MeJA em relação ao controle da fração S; elicitação de 60 minutos.

Figura 27. Teor de açúcar redutor em cultura de células de $R$. fruticosus com 60 minutos de elicitação; células de 18 dias, $8 \times 10^{4}$ cél. $/ \mathrm{mL}$ em $25 \mathrm{~mL}$ de amostra; F-I + AS, F-I + MeJA e AS + MeJA [1000 nmol/L].

Figura 28. Porcentagem (\%) de proteína total das amostras elicitadas com F-I, AS e MeJA [1000 nmol/L] em relação ao controle para a fração sobrenadante (fração $S$ ) de ensaios de elicitação de cultura de células de $R$. fruticosus, com tempo de elicitação de 60 minutos...

Figura 29. Teor de proteína total em cultura de células de $R$. fruticosus com 60 minutos de elicitação; células de 18 dias, $8 \times 10^{4}$ cél./mL em $25 \mathrm{~mL}$ de amostra; F-I, AS e MeJA [1000 nmol/L]

Figura 30. Porcentagem (\%) de proteína total das amostras elicitadas com $\mathrm{F}-\mathrm{I}+\mathrm{AS}, \mathrm{F}-\mathrm{I}+$ MeJA e AS + MeJA [1000 nmol/L] em relação ao controle na fração sobrenadante (fração $S$ ) de ensaios de elicitação de cultura de células de $R$. fruticosus, com tempo de elicitação de 60 minutos 
Figura 31. Teor de proteína total em cultura de células de R. fruticosus com 60 minutos de elicitação; células de 18 dias, $8 \times 10^{4}$ cél./mL em $25 \mathrm{~mL}$ de amostra; F-I +AS, F-I + MeJA e

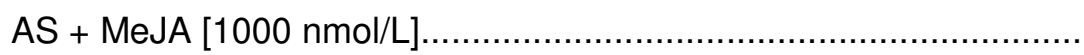


SUMÁRIO 
1. INTRODUÇÃO........................................................................... 32

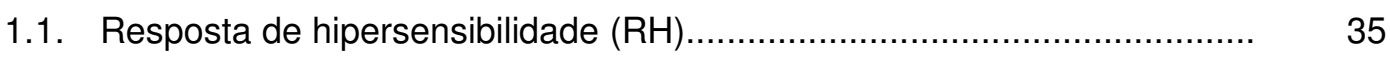

1.2. Espécies reativas de oxigênio (EROs) .......................................... 38

1.3. Parede celular e a defesa das plantas.......................................... 52

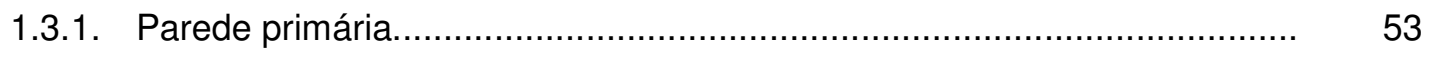

1.4. Moléculas sinalizadoras em plantas..................................................... 57

1.4.1. Oligossacarídeos e polissacarídeos.................................................. 57

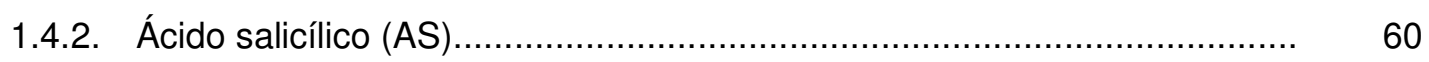

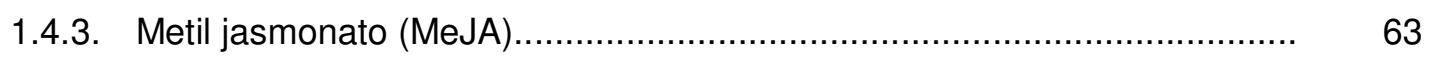

1.5. Estudos com Rubus fruticosus (amora-preta).................................... 66

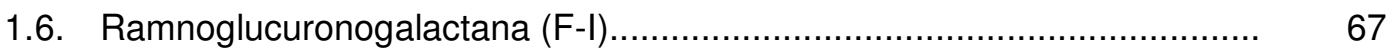

2. OBJETIVOS ............................................................................. 69

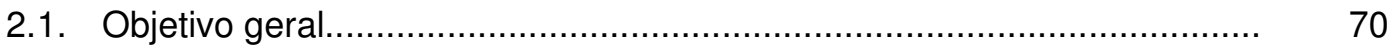



3. MATERIAL E MÉTODOS................................................................. 72

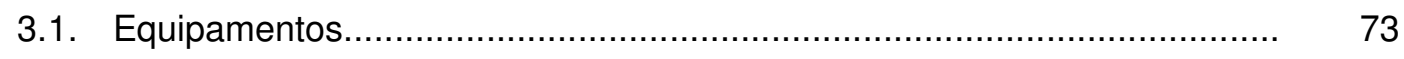

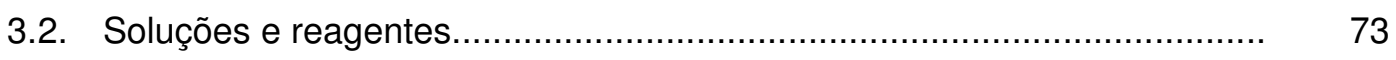

3.2.1. Ramnoglucuronogalactana (F-I) de Chorisia speciosa.......................... 74

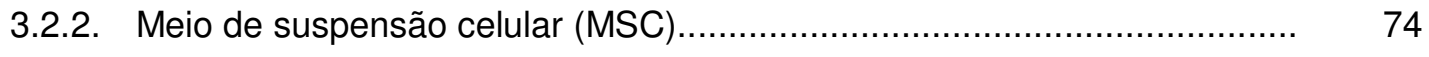

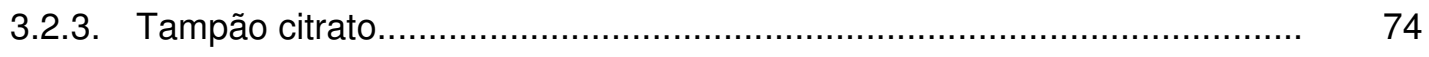

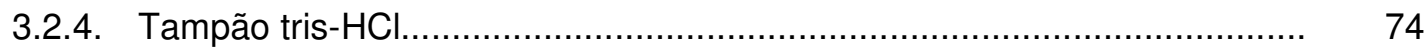

3.2.5. Meio de cultura de Heller.......................................................... 75

3.3. Preparação das células cultivadas................................................. 75

3.3.1. Contagem e viabilidade celular................................................... 76 
3.4. Detecção de espécies reativas de oxigênio (EROs).....

3.4.1. Padronização das condições experimentais para a detecção de espécies reativas de oxigênio

3.4.2. Análise do efeito de elicitores e de misturas de elicitores em diferentes tempos de elicitação.

3.5. Detecção do peróxido de hidrogênio $\left(\mathrm{H}_{2} \mathrm{O}_{2}\right)$

3.6. Ensaios de elicitação.

3.7. Padronização protocolo para análise dos componentes da parede celular

3.8. Preparação de amostras para análise da composição monossacarídica da parede celular

3.8.1. Hidrólise de Saeman

3.8.2. Redução de Wolfrom e Thompson

3.8.3. Acetilação de Wolfrom e Thompson.

3.8.4. Análise e quantificação por GLC

3.9. Dosagem de açúcar redutor pelo método do ferricianeto

3.10. Dosagem de proteína total pelo método de Bradford.

3.11. Isolamento dos componentes extracelulares das células elicitadas com os elicitores, suas misturas e os controles por cromatografia líquida de alta eficiência (CLAE)

3.12. Cromatografia em camada delgada (CCD)

3.13. Análise estatística dos resultados.

3.14. Padronização para os ensaios de elicitação das células de R. fruticosus.

4.1. Padronização das condições experimentais para a detecção de espécies 
reativas de oxigênio

4.2. Efeito de F-I, AS e MeJA sobre a produção de EROs em diferentes tempos de elicitação.

4.3. Efeito da mistura de elicitores sobre a produção de EROs em diferentes tempos de elicitação.

4.4. Efeitos dos elicitores sobre a produção de $\mathrm{H}_{2} \mathrm{O}_{2}$ em relação aos seus controles.

4.5. Efeitos das misturas de elicitores sobre a produção de $\mathrm{H}_{2} \mathrm{O}_{2}$

4.6. Análise dos açúcares liberados na fração $S$ por cromatografia em camada delgada (CCD)

4.7. Análise teor de açúcar liberado para o meio extracelular em células de R. fruticosus elicitadas com AS, F-I, MeJA e suas misturas.

4.8. Caracterização, por CLAE, dos carboidratos componentes da fração $S$ obtida das células de $R$. fruticosus elicitadas com AS, F-I, MeJA, $F-I+A S, F-I+M e J A$ e $A S+M e J A$

4.9. Análise do teor de proteínas liberadas para o meio extracelular em células de $R$. fruticosus elicitadas com AS, F-I, MeJA e suas misturas.....

4.10. Análise do efeito de AS, F-I e MeJA e suas misturas sobre os componentes da parede celular de $R$. fruticosus.

5. CONCLUSÕES 
1. INTRODUÇÃO 
As plantas, assim como os demais organismos, tiveram que desenvolver formas de adaptação e defesa para sobreviverem através dos tempos. O contato do agente patogênico com a planta pode gerar dois tipos de interações: o primeiro tipo é a interação compatível, quando o organismo hospedeiro é susceptível e não manifesta resistência; o segundo tipo é a interação incompatível, na qual o organismo hospedeiro gera resposta de defesa (DANGL; DIETRICH; THOMAS, 2000).

Há uma complexa cascata de transdução de sinais que é ativada, quando da detecção de um patógeno. Entre os mecanismos mais bem aceitos de reconhecimento planta-patógeno encontra-se o proposto por H.H. FLOR, na década de 50, que denominou sua hipótese de teoria gene-a-gene. De acordo com esta teoria, os patógenos possuem um gene dominante, denominado de gene de avirulência (gene Avr) que seria complementar a um gene dominante da planta, o gene de resistência (gene R). Os produtos do gene Avr são reconhecidos pelos produtos dos genes $R$, que funcionariam como receptores; e este reconhecimento desencadeia as respostas de defesa exibidas pela planta durante uma interação não compatível. A partir deste momento, diversos sinais são enviados através das células vegetais, provocando diversas respostas fisiológicas (FLOR, 1955; NIMCHUK et al., 2003).

Percepção e interrupção da penetração e/ou do ataque do patógeno estão entre os mecanismos primários de detecção associados com resistência a doenças em plantas. O maquinário de percepção da infecção patogênica pelas células hospedeiras inclue o "cross-linking" de proteínas da parede celular, produção de compostos fenólicos, alterações na composição da matriz péctica da parede celular, com formação de géis de pectato de cálcio; acúmulo de 
glicoproteínas e a geração de radicais livres. Comumente, a produção destes compostos acontece simultaneamente para construir uma eficiente e programada contenção da infecção na planta (AIST; BRUSHNELL, 1991; KIEFFER et al., 2000; MAZAU; ESQUÈRERRÉ-TUGAYÉ, 1986; THORDALL-CHRISTENSEN et al., 1997).

Talvez, o primeiro evento que ocorra após o reconhecimento do patógeno pela planta seja a despolarização da membrana plasmática e o fluxo de íons. De um modo geral ocorre influxo de íons cálcio $\left(\mathrm{Ca}^{2+}\right)$ para o citoplasma via ativação de canais de cálcio e, simultaneamente, uma troca de $\mathrm{K}^{+} / \mathrm{H}^{+}$na célula. Esse mecanismo foi observado quando culturas de células de tabaco em suspensão foram elicitadas por oligogalacturonídeos. Os canais de cálcio da membrana plasmática foram abertos, possivelmente, pela ativação da $\mathrm{H}^{+}$-ATPase que é ativada pela troca $\mathrm{K}^{+} / \mathrm{H}^{+}$na membrana. Isso causa uma alcalinização extracelular e uma acidificação intracelular. Em interações patógeno-planta o fluxo de íons é mediado por proteínas G. O aumento do cálcio intracelular leva à ativação de enzimas como a peroxidase de parede celular e a NADPH oxidase de membrana, que por sua vez, geram EROs. Além destes íons, existe a participação de moléculas como o ácido salicílico (AS) e o metil jasmonato (MeJA), os quais agem sobre a formação de radicais livres e também sobre a expressão de gene de resistência (ALLAN; FLUHR, 1997; ANDI et al., 2001; LAMB; DIXON, 1997).

Em plantas, a transdução de sinal é controlada pela fosforilação e desfosforilação de proteínas envolvendo as proteínas-quinase mitógeno ativadas (MAPKs). A indução de atividade das MAPKs tem sido verificada após a exposição das plantas à estresses diversos. Recentemente, foi descoberto que as EROs medeiam a ativação das cascatas de MAPKs e subseqüentes respostas de 
plantas a estímulos externos (MOON et al., 2003). As vias sinalizadoras de MAPK são compostas por três famílias distintas de proteínas-quinases: (i) a família das MAPK, (ii) a família das MAPK quinase (MAPKK) e (iii) a família das MAPKK quinase (MAPKKK). Durante a transdução de sinal, as MAPKKKs são fosforiladas e, desta forma, são capazes de ativar MAPKKs particulares. Estas MAPKKs tornam-se fosforiladas e então ativam MAPKs específicas. As MAPKs ativadas (MAPKs fosforiladas) freqüentemente são importadas para dentro dos núcleos, onde elas fosforilam e ativam componentes específicos de cascatas sinalizadoras tais como fatores de transcrição (KHOKHLATCHEV et al., 1998).

As plantas podem se defender dos ataques de agentes bióticos (patógenos e herbívoros) e abióticos (luz ultravioleta, metais pesados, condições de salinidade, entre outros), ativa ou passivamente, utilizando mecanismos de resistência. As plantas raramente experimentam condições de estresse que sejam causadas por uma única restrição ambiental. Infecção patogênica sob condições de campo é acompanhada, na maioria das vezes, por vários estresses abióticos adicionais tais como: lesão, deficiência em água e estresse mineral, causando interações multi-estresse (SCHIMID et al., 2005).

\subsection{Resposta de hipersensibilidade $(\mathbf{R H})$}

Os mecanismos de resistência são normalmente divididos em dois grupos principais: 1- resistência constitutiva ou pré-formada, aquela já presente na planta antes do contato com o agente agressor; 2- resistência adquirida ou pós-formada, a qual é produzida somente após o contato. As respostas pós-formadas podem ser locais, resposta de hipersensibilidade $(\mathrm{RH})$, ou manifestadas além do local de 
infecção, resposta sistêmica adquirida (RSA) (HAMMERSCHIMIDT, 1999; LAM et al., 2001; PASCHOLATTI; LEITE, 1995; STICHER MAUCH-MANI; MÉTRAUX, 1997).

Os organismos eucarióticos como plantas, animais e fungos desenvolveram formas de suicídio celular que é conhecida como morte celular programada (PCD), ou seja, é uma seqüência de eventos celulares que levam à morte da célula, sendo que a iniciação e a execução deste mecanismo são controladas pela própria célula (DANGL; DIETRICH; THOMAS, 2000). Ela é uma região restrita de células mortas que tem como intuito conter efetivamente os patógenos aos seus sítios de entrada. Adicionalmente, esse mecanismo tem a função de remover as células infectadas, assim como as células danificadas e indesejadas do organismo atacado (KERR; WYLLIE; CURRIE, 1972). Em outras palavras, morte celular programada é um fenômeno biológico geral de suicídio dirigido das células dos organismos afetados por eventos adversos, com o objetivo de dominar as invasões de agentes agressores ou manter a homeostase do metabolismo celular a valores biológicos normais (BEERS; McDOWELL, 2001). Um modelo bem caracterizado para estudos de morte celular programada é a resposta de hipersensibilidade, que é observada durante as interações entre planta e microrganismo (WYLLIE; KERR; CURRIE, 1980). A RH é usualmente definida como a rápida morte das células da planta em associação com a restrição do crescimento do patógeno (DANGL; DIETRICH; THOMAS, 2000).

A $\mathrm{RH}$ é um dos principais mecanismos de resistência encontrados nas plantas. Ela atua em resposta a um estímulo externo biótico ou abiótico sobre a planta. Deste modo, a resposta de hipersensibilidade é um mecanismo de resistência adquirida. A característica principal que diferencia a $\mathrm{RH}$ de outro tipo 
de mecanismo de resistência adquirida nas plantas, a resposta sistêmica adquirida (RSA), é que ela se manifesta no local da planta onde aconteceu o primeiro contato do componente externo biótico ou abiótico (STICHER; MAUCHMANI; MÉTRAUX, 1997).

Outra característica da $\mathrm{RH}$ é o fato de ser uma resposta de defesa rápida. Os eventos celulares envolvidos na $\mathrm{RH}$ iniciam-se imediatamente após o primeiro contato do patógeno com a planta. A ativação completa desta intensa resposta ao patógeno ocorre dentro de 24 horas e invariavelmente conduz, quer direta ou indiretamente, à morte localizada das células e tecidos. Esta rápida e altamente localizada indução de resposta de defesa da planta resulta em condições desfavoráveis ao estímulo agressor que, conseqüentemente, fica incapacitado de provocar qualquer dano em outros locais da planta. Os ataques subseqüentes por organismos necrotróficos oportunistas não ocorrem, pois as células mortas apresentam concentrações altas de moléculas antimicrobianas pré-formadas ou pós-formadas devido à $\mathrm{RH}$. Entre essas moléculas temos compostos fenólicos, sesquiterpenos, compostos derivados da via dos fenilpropanóides e moléculas derivadas dos flavonóides e isoflavonóides (BUCHANAN; GRUISSEM; JONES, 2000).

Os eventos citológicos que participam da ativação da morte celular, em diversos sistemas modelo de morte celular programada de plantas, englobam compostos tais como: ácido salicílico (AS), ácido jasmônico (AJ), etileno, as espécies reativas de oxigênio (EROs) peróxido de hidrogênio $\left(\mathrm{H}_{2} \mathrm{O}_{2}\right)$ e superóxido $\left(\mathrm{O}_{2}{ }^{-}\right)$, o óxido nítrico (NO) e as vias sinalizadoras de fluxo de íons (GUO; OKAMOTO; CRAWFORD, 2003; KHURANA; PANDEY; SARKAR, 2005). 
Várias mudanças celulares foram observadas durante o processo de morte celular decorrentes da resposta de hipersensibilidade. Entre elas estão: desaparecimento dos microtúbulos corticais, aparecimento de partículas nos vacúolos, desaparecimento gradual da atividade mitocondrial, clivagem do DNA nuclear, geração intracelular de $\mathrm{H}_{2} \mathrm{O}_{2}$, colapso de citoplasma e parada do fluxo citoplasmático (HEATH, 2000).

\subsection{Espécies reativas de oxigênio (EROs)}

A produção de EROs tem mostrado recentemente ser o mecanismo base das mudanças bioquímicas e fisiológicas que ocorrem sob condições de estresse ambiental, as quais por conseqüência medeiam a resistência a doenças em plantas (KOTCHONI; GACHOMO, 2006). É bastante aceito que as EROs possuam um papel central em muitas vias sinalizadoras durante a percepção de estresses, regulação da fotossíntese, resposta a patógenos, ação hormonal e no crescimento e desenvolvimento da planta (DAT et al., 2000; FOREMAN et al., 2003; MITTLER, 2002).

Os papéis das EROs na sinalização da morte celular foram demonstrados por TORRES, DANGL e JONES (2002), usando mutações de dois genes da Arabidopsis thaliana, rbohD e rbohF, que codificam sub-unidades catalíticas da NADPH oxidase, revelaram percepções do papel das EROs na indução da morte celular programada. A perda da função destes dois genes em mutantes de $A$. thaliana resultaram em decréscimo na produção de EROs durante a resposta de hipersensibilidade, com uma relacionada queda na morte celular. Esses 
resultados mostram a primeira evidência direta da implicação das EROs em resposta de morte celular via NADPH oxidases de plantas.

A maior parte do oxigênio circulante nos organismos aeróbicos é utilizado na mitocôndria para a produção de ATP (adenosina-5'-trifosfato). O oxigênio molecular pode ser reduzido monoeletronicamente durante o transporte de elétrons pela mitocôndria e podem gerar EROs que, desta forma, são detectadas como traços em vários compartimentos celulares. Outras fontes de EROs incluem enzimas como as peroxidases ligadas a parede celular e os cloroplastos (BANERJEE et al., 2003; DAVLETOVA et al., 2005; MITTLER, 2002).

As EROs são moléculas produzidas pelas células como uma conseqüência do metabolismo celular normal. No entanto, quando sujeitas aos estresses ambientais como frio, luz intensa, ozônio $\left(\mathrm{O}_{3}\right)$, seca, estresse salino, luz ultravioleta, intoxicação por metais pesados, lesões, bactérias, nematóides, fungos, insetos, vírus e moléculas elicitoras (moléculas capazes de induzirem respostas de defesa), uma excessiva quantidade de EROs é gerada (Figura 1). Este acúmulo excessivo de EROs necessita da ativação de defesas adicionais. A menos que estas EROs sejam metabolizadas efetivamente, elas rapidamente oxidam e danificam lipídeos de membranas, proteínas e outros componentes celulares e, conseqüentemente, conduzindo à disfunção celular e por último à morte celular, ou ao aparecimento de lesões necróticas (DOKE, 1997; FOYER; NOCTOR, 2005). 




Figura 1. Envolvimento das EROs em processos metabólicos de resposta das plantas a vários estresses ambientais. I e II indicam os eventos celulares subseqüentes mediados pelas EROs em células de plantas expostas a estresses abióticos. I' e II' indicam os eventos celulares subseqüentes mediados pelas EROs em células de plantas expostas a patógenos e elicitores patogênicos. A resistência das células de plantas as condições de estresse é dependente da intensidade e da velocidade destes eventos celulares (adaptado de KOTCHONI; GACHOMO, 2006). 
O "burst" oxidativo envolve a ativação de componentes de oxidases pré-existentes mais do que a síntese do maquinário do "burst" oxidativo. O mecanismo que as plantas possuem para gerar $\mathrm{O}_{2}^{-{ }^{-}}$a partir do oxigênio molecular, possivelmente envolve uma NADPH oxidase associada à membrana. Há indicações de que plantas e mamíferos geram EROs de maneira similar durante as respostas de defesa. Contudo, a presença de um receptor, no qual o cálcio se liga a NADPH oxidase vegetal, sugere a possibilidade de regulação direta da atividade dessa oxidase, através da percepção de trocas de concentrações subcelulares de cálcio, em vez da montagem de oxidases citoplasmáticas adicionais, como ocorre em sistemas de defesa de mamíferos (HAMMOND-KOSACK; JONES, 2000). Um exemplo são os componentes citosólicos pré-formados como o $\mathrm{Ca}^{2+}$ e o ATP que contribuíram para aumentar a atividade in vitro da NADPH oxidase associada à membrana plasmática de células de tubérculos de batata infectados por Phytophthora infestans (ALLAN; FLUHR, 1997). Além disso, a incubação de fatias de tubérculo de batata com $P$. infestans estimula a NADH oxidase, a qual está severamente submetida ao controle do acúmulo de $\mathrm{O}_{2}{ }^{-}$. Isto evidencia o papel das EROs para mediar a expressão de mecanismos de defesa em plantas (DOKE; MUIRA, 1995).

O "burst" oxidativo inicia-se a partir do oxigênio molecular $\left(\mathrm{O}_{2}\right)$. As EROs podem ser geradas dentro das células das plantas como resultado da excitação (entrada de energia) no elétron externo do oxigênio molecular, formando oxigênio singleto $\left({ }^{1} \mathrm{O}_{2}\right)$ ou de uma sucessiva adição de elétrons ao oxigênio molecular gerando $\mathrm{O}_{2}^{-\cdot}, \mathrm{H}_{2} \mathrm{O}_{2}$ e o radical hidroxila $(\cdot \mathrm{OH})$ (Figura 2). Essas moléculas, descritas a seguir, são consideradas "ativas", pois podem reagir prontamente com 
outras moléculas, retirando-Ihes elétrons (oxidação) (RESENDE; SALGADO; CHAVES, 2003).

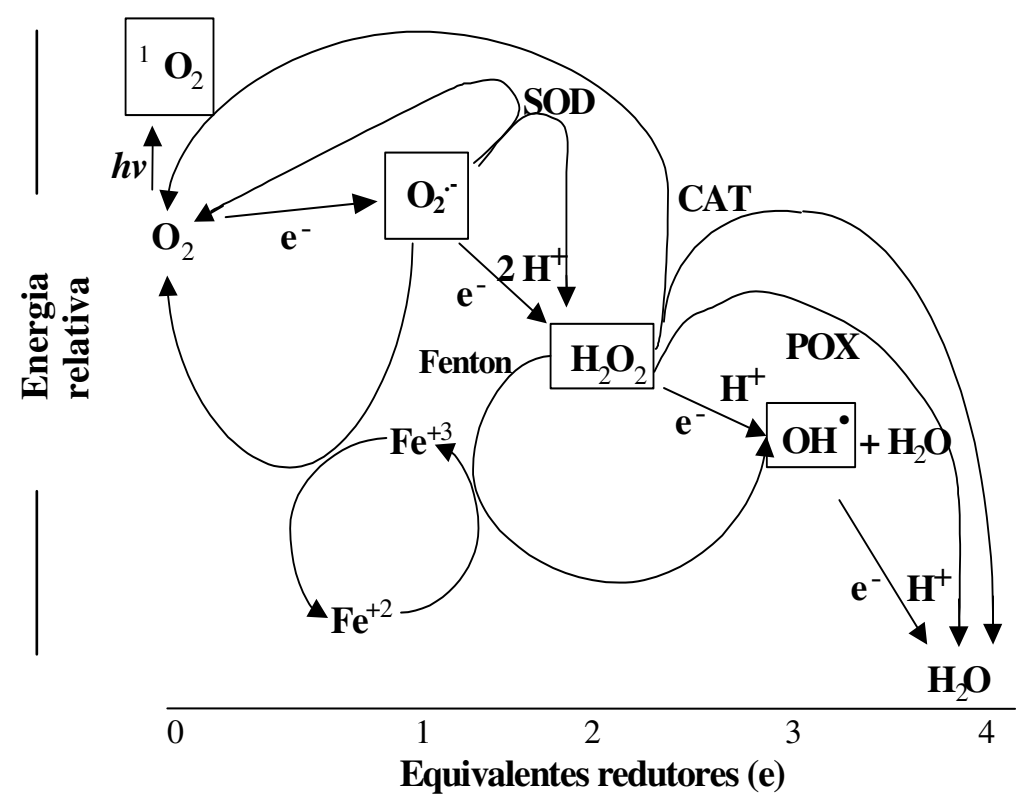

Figura 2. Fluxo de elétrons durante o "burst" oxidativo: espécies reativas de oxigênio (EROs) derivadas do $\mathrm{O}_{2}$, via de detoxificação (limpeza) e inter-conversões em plantas (adaptado de BAKER; ORLANDI, 1999).

O ânion superóxido $\left(\mathrm{O}_{2}{ }^{-}\right)$pode ser produzido na planta por meio de vários mecanismos, inclusive pela ativação de NADPH-oxidases ou NADPH-sintases ligadas à membrana, peroxidases da parede celular, lipoxigenases (LOX) e como resultado da transferência de elétrons presentes na mitocôndria ou no cloroplasto. Ele possui um tempo de meia-vida da ordem de $10^{-6}$ segundos. $O$ radical superóxido $\left(\mathrm{O}_{2}^{-}\right)$é o primeiro radical produzido que desencadeia a produção de outras espécies reativas de oxigênio (EROs) e do próprio $\mathrm{H}_{2} \mathrm{O}_{2}$ (BREUSEGEM et al., 2001). 
A maioria do peróxido de hidrogênio $\left(\mathrm{H}_{2} \mathrm{O}_{2}\right)$ surge da dismutação do $\mathrm{O}_{2}{ }^{-}$ catalisada pela superóxido dismutase (SOD). Dismutação é uma reação na qual 2 moléculas idênticas são transformadas em compostos diferentes. A enzima SOD catalisa uma conversão altamente eficiente de $\mathrm{O}_{2}{ }^{--}$a $\mathrm{H}_{2} \mathrm{O}_{2}$, numa velocidade $10^{10}$ vezes maior que na reação espontânea. O peróxido de hidrogênio é um oxidante relativamente estável e ausente de carga, o que pode facilitar a passagem através da camada bilipídica da membrana celular. Essa capacidade de difundir-se rapidamente através da membrana celular favorece a rápida elicitação da resposta vegetal verificada por esta molécula (APOSTOL; HEINSTEIN; LOW, 1989; CLEMENTS; SAFFREY, 2001; GERSHENZON, 2002).

Radicais hidroxila $(\mathrm{OH})$ são radicais potencialmente fortes e com alta afinidade pelas biomoléculas no seu sítio de produção, possuindo meia-vida curta de $10^{-9} \mathrm{~s}$ (YU, 1994). Normalmente, oxida várias moléculas orgânicas, como o ascorbato, ou pode agir como redutor de metais como $\mathrm{Fe}^{3+}$, na reação de Fenton. Esta reação leva à produção de $\mathrm{OH}$ (radical hidroxila), um componente extremamente tóxico (BREUSEGEM et al., 2001).

\section{Reação de Fenton}

I) $\mathrm{Fe}^{3+}+\mathrm{O}_{2}^{--} \rightarrow \mathrm{Fe}^{2+}+\mathrm{O}_{2}$

II) $\mathrm{Fe}^{2+}+\mathrm{H}_{2} \mathrm{O}_{2} \rightarrow \mathrm{Fe}^{3+}+\mathrm{OH}^{-}+\mathrm{OH}$

Semelhante aos radicais hidroxilas, os oxigênio singleto $\left({ }^{1} \mathrm{O}_{2}\right)$ têm aproximadamente $10^{-5} \mathrm{~s}$ de vida e é altamente destrutivo, reagindo com a maioria das moléculas biológicas (FOYER; LELANDAIA; KUNERT, 1994). A maioria dos 
danos é próxima aos sítios aonde são produzidos. Eles são quase sempre gerados nos cloroplastos, através da transferência de energia de uma clorofila foto-excitada para o elétron do oxigênio molecular. $\mathrm{O}^{1} \mathrm{O}_{2}$ e as outras EROs têm alta afinidade por aminoácidos específicos como histidina, metionina, triptofano e cisteína (RESENDE; SALGADO; CHAVES, 2003).

Em animais, as EROs estão sendo implicadas em inflamação e câncer. Porém, nas interações planta-patógeno foi sugerido que as EROs possam participar do sistema de defesa da planta de muitas maneiras, inclusive agindo como agentes sinalizadores ou causando um reforço da parede celular através do “cross-linking” oxidativo (BRISSON; TENHAKEN; LAMB, 1994).

As EROs têm destaque em vias de transdução de sinal de genes induzidos pelo estresse em plantas superiores e uma quantidade balanceada de EROs é crucial para muitos processos metabólicos diferentes. A manipulação dos níveis de EROs em plantas tem sido proposta com uma promissora ferramenta para gerar plantas transgênicas que possam resistir a múltiplos estresses ambientais (BARTELS, 2001).

Embora a natureza química e a reatividade das EROs provarem ser potencialmente prejudiciais as células, as plantas utilizam estas moléculas como mensageiros secundários nas cascatas de transdução de sinais regulando diversos processos como, por exemplo, as mitoses, morte celular e mecanismos de defesa (PAVET et al., 2005).

As EROs são conhecidas por ter um duplo papel dependendo dos seus níveis de acúmulo no interior da célula. Concentrações intracelulares altas de EROs podem ocasionar extensiva morte celular. Os níveis de EROs precisam, portanto, ser regulados rigorosamente para evitar danos celulares (NEILL; 
DESIKAN; HANCOCK, 2002). Um acúmulo moderado de EROs funciona como um indutor chave para programação do metabolismo secundário, sinais de defesa, diferenciação da parede celular e ativação das proteínas-quinase mitógeno ativadas (MAPKs), levando a planta à uma tolerância ao estresse ambiental (CONRATH; PIETERSE; MAUCH-MANI, 2002).

Se as EROs medeiam a resposta de morte celular observada na $\mathrm{RH}$, tratamentos com EROs similares mimetizam a $\mathrm{RH}$ causada por um patógeno incompatível. Os diferentes papéis das EROs na $\mathrm{RH}$ devem ser concentração dependente. Altas concentrações podem causar morte, enquanto baixas concentrações podem estar envolvidas na sinalização. $\mathrm{O} \mathrm{H}_{2} \mathrm{O}_{2}$ produzido durante a $\mathrm{RH}$ tem demonstrado atingir a transcrição de genes codificadores de proteínas antioxidantes em tecidos adjacentes. Isto sugere que quantidades baixas de EROs podem também sinalizar o hospedeiro a fabricar protetores celulares endógenos, tais como os sistemas antioxidantes, possivelmente, para limitar a extensão da morte celular (BUCHANAN; GRUISSEM; JONES, 2000).

Portanto, como o acúmulo de EROs pode resultar em prejuízos consideráveis, a célula dispõe de vários mecanismos para detoxificar essas espécies ativas de oxigênio. Esses mecanismos de proteção foram desenvolvidos pelas plantas durante o processo de evolução para controlar os níveis dessas moléculas e anular essa toxicidade. Dentre os mecanismos de proteção estão as enzimas antioxidantes (RESENDE; SALGADO; CHAVES, 2003).

As superóxido dismutases (SODs) são enzimas catalisadoras da dismutação do $\mathrm{O}_{2}{ }^{--}$a $\mathrm{H}_{2} \mathrm{O}_{2}$, e podem estar ligadas a um metal ( $\mathrm{Cu} / \mathrm{Zn}, \mathrm{Mn}$ e $\mathrm{Fe}$ ). As plantas, normalmente, têm Cu/Zn-SOD no citosol, Cu/Zn e/ou Fe-SOD no cloroplasto e Mn-SOD na mitocôndria. Por exemplo, quatro diferentes isoenzimas 
de SOD - CuZn-SOD (CSD2) e três Fe-SODs - e enzimas do ciclo ascorbato-glutationa, capazes de reduzirem glutationa e ácido ascórbico oxidados, foram identificados em cloroplastos (ASADA; TAKAHASHI, 1987).

As catalases (CATs) são enzimas que convertem o $\mathrm{H}_{2} \mathrm{O}_{2}$ em $\mathrm{H}_{2} \mathrm{O}$ e $\mathrm{O}_{2}$. As plantas possuem várias isoformas de catalase. As catalases podem ser divididas em três classes: as catalases da classe 1 que removem o $\mathrm{H}_{2} \mathrm{O}_{2}$ produzido durante a fotorespiração em tecidos fotossintéticos. As catalases da classe 2 que são produzidas em tecidos vasculares. E na classe 3 estão as catalases presentes abundantemente em sementes e plantas jovens, e cuja atividade está relacionada à remoção do $\mathrm{H}_{2} \mathrm{O}_{2}$ produzido durante a degradação dos ácidos graxos (BREUSEGEM et al., 2001).

As peroxidases (PODs) catalisam a reação do $\mathrm{H}_{2} \mathrm{O}_{2}$ com um substrato redutor, gerando $\mathrm{H}_{2} \mathrm{O}$. Os cloroplastos de Arabidopsis thaliana possuem a enzima ascorbato peroxidase (APX) que regula os níveis de $\mathrm{H}_{2} \mathrm{O}_{2}$ (APEL; HIRT, 2004).

O envolvimento das espécies reativas de oxigênio (EROs) na morte celular programada foi também demonstrado pela detecção de EROs durante as fases precoces e tardias da interação planta-patógeno. Duas fases de indução de EROs por elicitores fúngicos e bacterianos têm sido avaliadas em culturas de células vegetais. A fase I corresponde àquela de resposta muito rápida na primeira hora de contato das células com os elicitores (BAKER; ORLANDI, 1995). Embora a produção de EROs na fase I, possivelmente, envolva uma interação elicitor-receptor, as respostas não estão sempre correlacionadas com resistência a fito-doenças, podendo também ocorrer em interações compatíveis. Na fase II de produção de espécies reativas de oxigênio, ocorre um "burst" mais forte e prolongado, o qual está diretamente correlacionado com a resistência da planta 
ao patógeno, provocando a morte localizada de células (Figura 3) (DANGL; DIETRICH; THOMAS, 2000).

Para interações incompatíveis, como é o caso da $\mathrm{RH}$, um primeiro "burst" oxidativo ocorre dentro da primeira hora da inoculação do componente avirulento. Um segundo "burst" oxidativo, que é característico das interações incompatíveis, ocorre de forma mais forte e mais prolongada no tempo de quatro horas da inoculação (BUCHANAN; GRUISSEM; JONES, 2000).

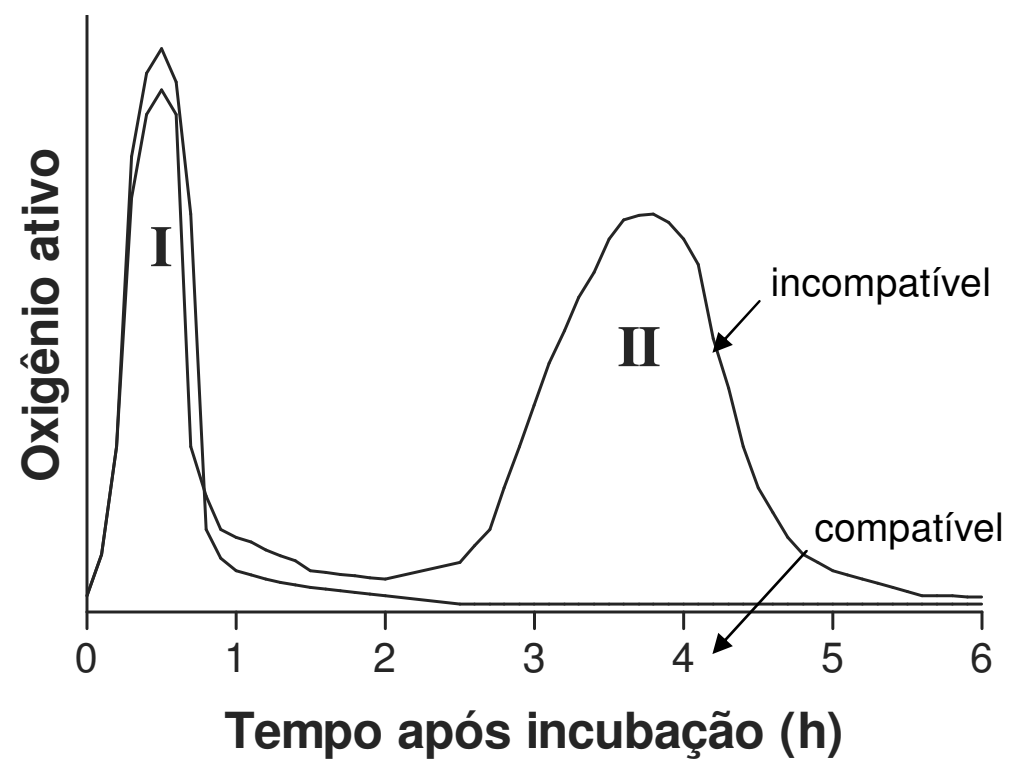

Figura 3. Fases da produção de EROs na interação planta-bactéria (adaptado de BAKER; ORLANDI, 1995).

Os elicitores derivados de patógenos provocam a biossíntese muito rápida de EROs (menos de 5 minutos), que requer $\mathrm{Ca}^{2+}$ externo e a ativação de canais de íons. Contrariamente, bactérias avirulentas provocam um pequeno "burst" oxidativo. Este atraso reflete o tempo requerido para o sinal da bactéria avirulenta ser liberado para as células da planta e processado para uma forma que possa elicitar o mecanismo de reconhecimento (BAKER et al., 1991; KEPPLER; 
BAKER; ATKINSON, 1989; KEPPLER; BAKER, 1989). Por outro lado, o acúmulo de EROs inibe o transporte de elétrons mitocondriais, conduzindo a queda no nível de ATP. Tanto a depleção de ATP quanto o acúmulo de EROs levam rapidamente ao influxo de $\mathrm{Ca}^{2+}$, os quais disparam a morte celular programada em plantas (JONES, 2000).

O peróxido de hidrogênio é um substrato aceptor de elétrons para as peroxidases (POD) de plantas. Assim, nesta interação, entre o doador e o aceptor de elétrons, vários canais de íons são ativados, dentre os quais os canais de cálcio são os predominantes. Estas vias sinalizadoras de íons levam às mudanças no $\mathrm{pH}$ intracelular necessárias para a ativação subseqüente dos mecanismos protetores das plantas (KAWANO et al., 2000).

MELLERSH e colaboradores (2002) demonstraram que a geração localizada de $\mathrm{H}_{2} \mathrm{O}_{2}$ é uma das primeiras respostas de defesa, citologicamente detectáveis, à penetração da parede celular da planta por vários fungos patogênicos. A geração rápida de $\mathrm{H}_{2} \mathrm{O}_{2}$, em resposta a penetração celular, é um dos determinantes mais importantes do fracasso na invasão das células epidermais. Por outro lado, a remoção enzimática de $\mathrm{H}_{2} \mathrm{O}_{2}$ resultou no aumento do sucesso da penetração de fungos em células de plantas hospedeiras.

$\mathrm{Na}$ sinalização para respostas de defesa da planta ao patógeno, $\mathrm{O}_{2} \mathrm{O}_{2}$ é o composto mais efetivo dentre as EROs, por causa da sua vida relativamente longa e a alta permeabilidade através das membranas. Desse modo, após o reconhecimento do patógeno avirulento seguido do "burst" oxidativo e seus intermediários reativos, ocorre indução de genes de defesa e morte celular, onde o $\mathrm{H}_{2} \mathrm{O}_{2}$ age como um sinalizador para indução de genes de proteção celular nas células vizinhas para restringir o desenvolvimento da lesão $(R H)$, que é, então, 
acompanhado pelo desenvolvimento de uma resistência (resposta) sistêmica adquirida (RSA). Isso foi comprovado por ALVAREZ e colaboradores (1998), após a inoculação da bactéria Pseudomonas syringae pv. tomato (Okabe) ( $\underline{\text { st }})$, contendo o gene de avirulência avrRpt2, em folhas de Arabidopsis thaliana, possuidora do gene de resistência Rps2. A bactéria causou uma $\mathrm{RH}$ macroscópica no sítio de inoculação, e o desenvolvimento de RSA em folhas não inoculadas (secundárias).

Sob ataque patogênico, o metabolismo de EROs é regulado por uma rede sinalizadora envolvendo cerca de 152 genes em $A$. thaliana (MITTLER et al., 2004). A rede sinalizadora controla a taxa de produção de EROs e das enzimas antioxidantes nos diferentes compartimentos; e modula o nível basal de EROs para sinalização justamente com o propósito de defesa. A geração de $\mathrm{H}_{2} \mathrm{O}_{2}$ e os genes induzidos pelo estresse atuam dentro das vias de inibição da penetração, possivelmente por meio do envolvimento de compostos fenólicos. $\mathrm{O}_{2} \mathrm{O}_{2}$ muito provavelmente atua em uma via envolvendo a transcrição, tradução e a expressão de respostas associadas à parede celular como o acúmulo de compostos inibidores de fungos (AIST; BRUSHNELL, 1991). No entanto, embora concentrações sub-letais de $\mathrm{H}_{2} \mathrm{O}_{2}$ induzam a expressão de genes de defesa, a indução completa dos genes de defesa e morte celular requer moléculas sinalizadoras adicionais como o AS (RAO; DAVIS, 1999). Estes estudos sugerem que as EROs requerem componentes adicionais para as cascatas sinalizadoras, a fim de transduzir, ou amplificar, o sinal (BOLWELL, 1999). Uma pequena alteração no nível de EROs intracelular dispara, portanto, a expressão de uma classe específica de genes, que codificam proteínas antioxidantes, através da 
cascata de fosforilação de proteínas via proteínas MAPK ativadas (BORSANI; VALPUESTA; BOTELLA, 2003).

A conecção entre a ativação das cascatas de MAPK de plantas e a ação mediadora de EROs $\left(\mathrm{H}_{2} \mathrm{O}_{2}\right)$ tem sido demonstrada usando o ensaio de expressão transitória de protoplastos de Arabidopsis. Este processo interativo realça o papel pivô das EROs como ativadoras chave das cascatas de MAPK e a subseqüente expressão de determinados genes. KOVTUN e colaboradores (2000) mostraram que a classe de MAPK quinase-quinases (MAPKKKs) ANP (Nicotina proteína quinase) de Arabidopsis é induzida especificamente pelo $\mathrm{H}_{2} \mathrm{O}_{2}$, o qual induz em seqüência a ativação de outras classes específicas de MAPKs em plantas sujeitas a estresse ambiental.

Além da atuação no complexo e integrado sistema de sinalização celular que culminará na ativação da expressão dos genes de defesa, o $\mathrm{H}_{2} \mathrm{O}_{2}$ participa do "cross-linking" de proteínas da parede celular formando, com a matriz de polissacarídeos, um grande polímero de várias glicoproteínas estruturais ricas em hidroxiprolina, as estensinas, reforçando estruturalmente a parede celular (ALVAREZ et al., 1998).

Em folhas de tomate, as lesões induzem a ativação de poligalacturonases que, por sua vez, levam a produção de fragmentos de oligogalacturonídeos, os quais induzem a geração de EROs próximas as paredes celulares das células. $O$ $\mathrm{H}_{2} \mathrm{O}_{2}$ resultante deste estímulo pode atuar com um segundo mensageiro para a ativação de genes de defesa em células de plantas (OROZCO-CÁRDENAS; NARVÁES-VÁSQUES; RYAN, 2001).

O "burst" oxidativo é necessário, mas não é suficiente para iniciar o processo de morte celular $(\mathrm{RH})$. Dados recentes citados por DELLEDONNE e 
colaboradores (2001) indicam que o óxido nítrico (NO) coopera com as EROs na ativação da $\mathrm{RH}$. Então, aparentemente o $\mathrm{NO}$ possui efeito sinérgico com $\circ \mathrm{H}_{2} \mathrm{O}_{2}$ na indução de $\mathrm{RH}$. Tem sido proposto que o balanço intracelular entre as concentrações de $\mathrm{NO}$ e peróxido de hidrogênio $\left(\mathrm{H}_{2} \mathrm{O}_{2}\right)$, mas não superóxido, é a chave determinante para a resposta de morte celular por resposta de hipersensibilidade (RH) (DELLEDONNE et al., 2001). O NO e as EROs interferem geralmente na atividade da fenilalanina amônia liase (PAL), e também no metabolismo da ascorbato peroxidase (APX) e da glutationa (GSH). Baseado nas contribuições de pesquisas, a simultânea implicação de induzir a PAL e o metabolismo da GSH e da APX é que medeiam a indução da morte celular programada (KHURANA; PANDEY; SARKAR, 2005). Em adição, NO coopera com AS para induzir $\mathrm{RH}$ e defesas adquiridas, o qual é análogo ao seu papel em sistemas animais (DURNER; WENDEHENNE; KLESSIG, 1998). Produção aumentada de NO é suficiente para induzir morte celular em uma cultura de células de $A$. thaliana (CLARKE et al., 2000).

Com respeito a uma maior contribuição das pesquisas em direção a elucidação das vias sinalizadoras de moléculas que medeiam os mecanismos de resistência ambiental em plantas, nós ainda temos apenas uma visão fragmentada das vias relevantes. Algumas das questões permanentes incluem: a identidade dos receptores das cascatas sinalizadoras; os substratos de várias quinases; quais loci diretamente, ou indiretamente, interagem durante as vias sinalizadoras de espécies reativas de oxigênio (EROs); a identidade de elementos sinalizadores adicionais, ligando os elementos já conhecidos e caracterizados, para completar a rede de vias e montar os mecanismos de defesa apropriados em plantas. Além disso, a interação das infecções patogênicas com 
outros fatores de estresse deve ser investigada em experiências de campo a fim de realmente entendermos os mecanismos de defesa das plantas, além da fronteira dos experimentos de laboratório, para podermos avaliar e trazer benefícios para várias produções agrícolas importantes (KOTCHONI; GACHOMO, 2006).

\subsection{Parede celular e a defesa das plantas}

As células vegetais são envolvidas por uma parede celular, que é uma matriz elaborada que circunda cada célula da planta e possui algumas funções específicas como sustentação, manutenção da forma da célula, resistência mecânica, controle da expansão celular, participação nos mecanismos de proteção contra microrganismos, armazenamento de material de reserva e participação na sinalização e reconhecimento entre as células, além de ter efeitos sobre o transporte intercelular e sobre o potencial de água da célula. Esta multiplicidade de funções talvez esteja associada à grande complexidade de sua estrutura (WILSON et al., 2000).

A parede celular vegetal não é simplesmente um exoesqueleto estático e inerte, mas serve também como uma matriz extracelular que interage com as proteínas da superfície celular, propiciando informações sobre desenvolvimento e posição. A parede celular contém inúmeras enzimas e pequenas moléculas que possuem atividade biológica e podem modificar tanto física quanto quimicamente a característica da própria parede. Em alguns casos, as moléculas derivadas das paredes também podem atuar como sinalizadoras para informar à célula sobre condições ambientais, como a presença de patógenos, sendo este um aspecto 
muito importante na defesa das plantas contra microrganismos invasores. As paredes celulares podem também modificar a sua morfologia durante ataque patogênico, formando uma barreira física que impede a penetração do invasor. Desta forma, as hemiceluloses e pectinas da parede celular primária podem ser modificadas e clivadas por uma variedade de enzimas que são encontradas naturalmente na parede celular (ROSE; BENETT, 1999).

\subsubsection{Parede primária}

A parede primária é uma fina camada produzida a partir da divisão celular, sendo composta basicamente de celulose, hemicelulose, substâncias pécticas e proteínas. A mesma confere rigidez e força com investimento relativamente pequeno em material (COSGROVE, 2005; JARVIS; McCANN, 2000). A sua extraordinária complexidade estrutural é evidenciada pela diversidade de polissacarídeos e glicoproteínas (McNEIL et al., 1984) de arquitetura precisamente regulada (CHANLIAUD et al., 2004), sendo muitas vezes considerada um mecanismo exemplar de engenharia (ROSE; BENNETT, 1999).

É composta de aproximadamente $90 \%$ de polissacarídeos e $10 \%$ de proteínas, sendo estas últimas pertencentes ao conjunto de glicoproteínas, moléculas particularmente presentes na parede primária (FOSKET, 1994).

Uma das mais relevantes tarefas desempenhadas pela parede celular primária é a capacidade de expansão, em resposta à pressão de turgor exercida dentro da própria célula (JARVIS; McCANN, 2000; O’NEILL et al., 2001). O crescimento da parede ocorre sob o aspecto temporal, iniciando por intensa divisão celular, de maneira lenta. Após cessar a atividade meristemática, segue a 
etapa de vacuolização celular caracterizando o processo de expansão, acompanhado pela alteração na deposição de materiais de parede e ação específica de enzimas (COSGROVE, 2000). Estas enzimas seletivamente afrouxam a rede de polissacarídeos (COSGROVE, 2001), atuando principalmente na interação entre microfibrilas de celulose e cadeias de xiloglucanas (CARPITA; GIBEAUT, 1993; CHANLIAUD et al., 2004; McQUEENMASON; COSGROVE, 1994; VARNER; LIN, 1989; WHITHNEY et al., 1999).

As ações coordenadas das glicosidases e endoglicosidases promovem a clivagem de polissacarídeos e uma conseqüente perda de interação entre os componentes da parede celular, compensada pela ação das transglicosilases, responsáveis pela reestruturação de segmentos de polissacarídeos; o que pode ocorrer de duas formas: um polissacarídeo sintetizado reagir com outro previamente ligado à parede, ou, um polissacarídeo previamente ligado à parede ligar-se a outro. (THOMPSON; FRY, 2001).

Hipóteses sobre a arquitetura e dinâmica da expansão celular tiveram início na década de 70. Inicialmente, foi proposto que os componentes da matriz polimérica, consistindo de xiloglucanas, polissacarídeos pécticos e proteínas estruturais estariam covalentemente ligados, formando uma gigantesca rede macromolecular, permanecendo as microfibrilas de celulose ligadas à matriz por pontes de hidrogênio apenas em alguns sítios de ligação. Esta discussão deu origem ao modelo de "ALBERSHEIM", que descreve ainda a redução do pH resultando no enfraquecimento das pontes de hidrogênio, conseqüentemente levando ao afrouxamento da parede (KEEGSTRA et al., 1973).

HAYASHI, MARSDEN e DELMER (1987) propuseram que as microfibrilas de celulose seriam interconectadas por pontes de hidrogênio ao longo das 
cadeias de xiloglucanas. Polissacarídeos pécticos e proteínas participariam independentemente, envolvendo o complexo celulose-xiloglucana de maneira não covalente. A idéia evoluiu para o modelo de "CARPITA" (CARPITA; GIBEAUT, 1993), atualmente mais aceito. Este aborda a arquitetura e dinâmica de crescimento da parede celular de dicotiledôneas referenciadas como parede celular do tipo I, assim como de monodicotiledôneas tais como as gramíneas, denominada pelos autores de parede do tipo II.

As paredes do tipo I seriam constituídas fundamentalmente por três domínios. O primeiro composto por uma rede de microfibrilas de celulose de 5 a $15 \mathrm{~nm}$ de largura e espaçadas de 20 a $40 \mathrm{~nm}$, enoveladas e interconectadas pelas cadeias de xiloglucanas e outros polissacarídeos hemicelulósicos, tais como (galacto) glucomananas, galactomananas, (1-3) $\beta$-D-glucanas e glucuronoarabinoxilanas, porém em menores quantidades. Toda a rede de polissacarídeos estaria embebida em uma matriz péctica, formada principalmente por homogalacturonanas e ramnogalacturonanas do tipo I (RG-I), sendo então o segundo domínio. O terceiro domínio consiste de proteínas estruturais. As extensinas (glicoproteínas ricas em hidroxiprolina) são as principais proteínas nas paredes celulares do tipo I (Figura 4).

As paredes do tipo II são compostas pelas microfibrilas de celulose, envolvidas e interconectadas pelas cadeias de glucuronoarabinoxilanas, da mesma forma que ocorre com a xiloglucana, nas paredes do tipo I. As pectinas também se encontram presentes, formadas pelas cadeias de ácido poligalacturônico e ramnogalacturonana do tipo I (RG-I), com cadeias laterais podendo ser constituídas por arabinanas, galactanas ou arabinogalactanas (Figura 5). 

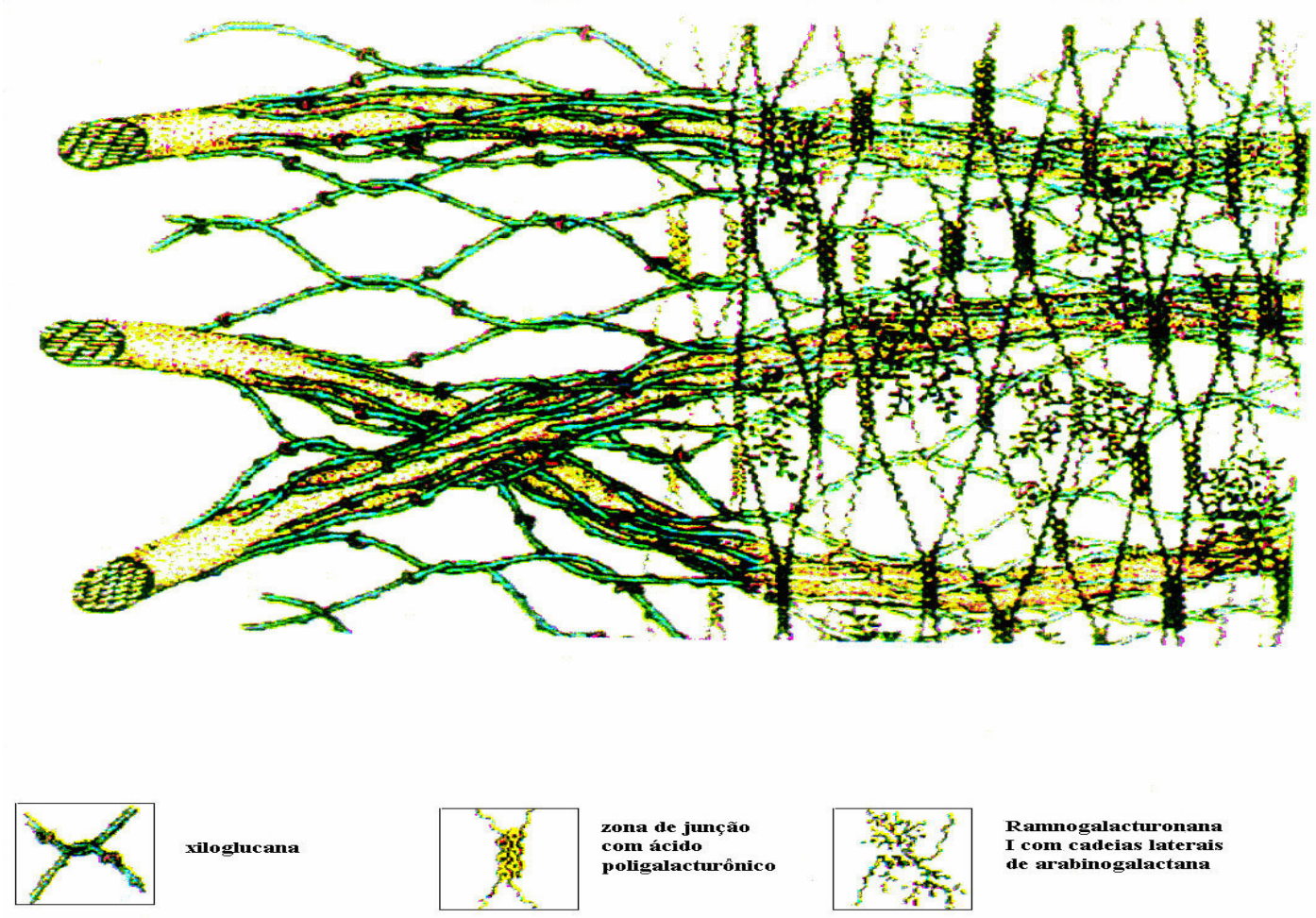

Figura 4. Modelo de parede celular primária do tipo I (adaptado de CARPITA; GIBEAUT, 1993).

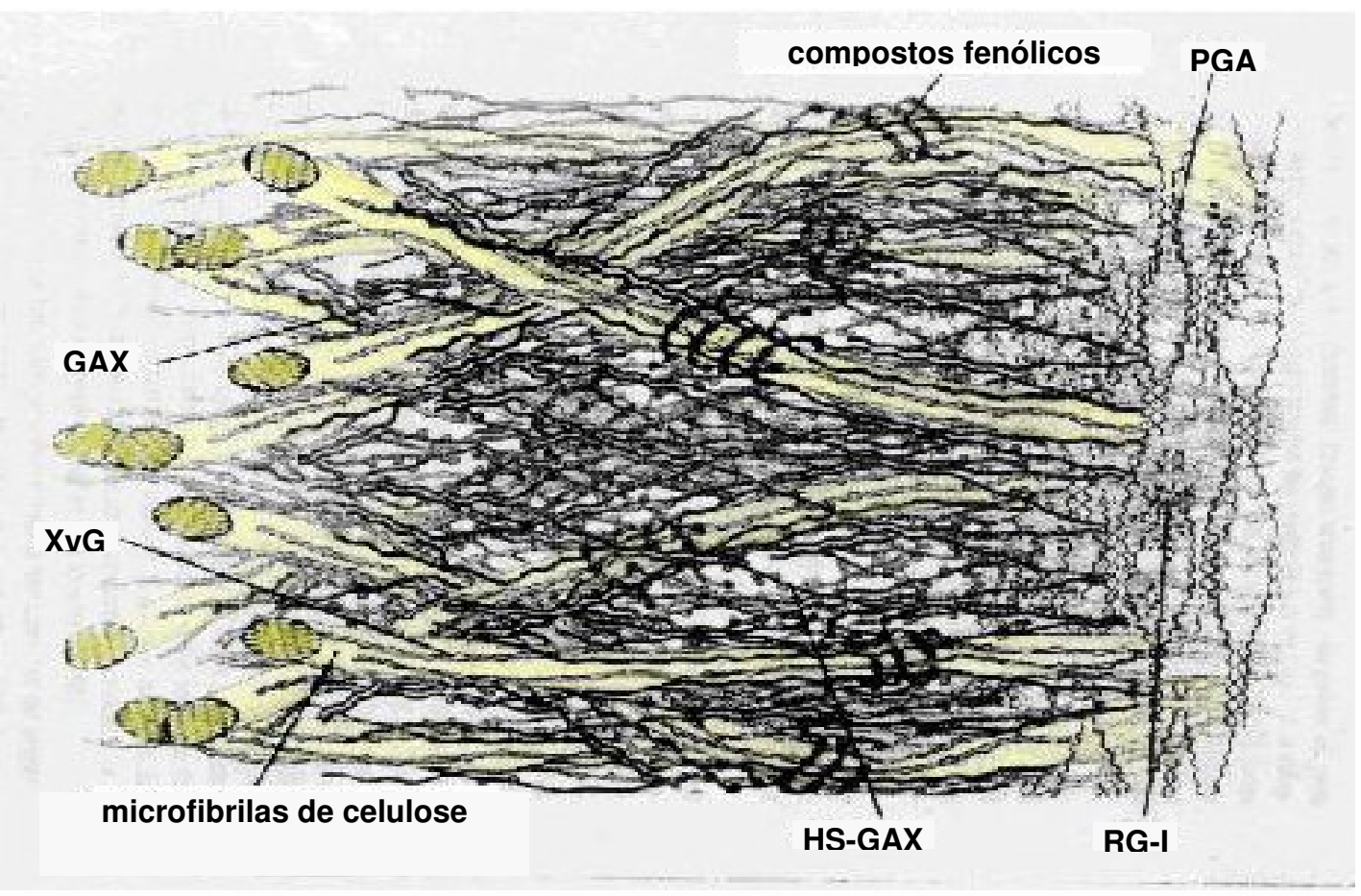

Figura 5. Modelo de parede celular primária do tipo II (adaptado de CARPITA, 1996). GAX: glucuronoarabinoxilana; HS-GAX: glucoroarabinoxilana altamente substituída, com 
6 ou 7 unidades de xilosil; PGA: ácido poli-galacturônico; RG-I: ramnogalacturonana do tipo I; XyG: xiloglucana.

\subsection{Moléculas sinalizadoras em plantas}

A detecção de patógenos pelas plantas é mediada por substâncias químicas secretadas ou gerada pelos próprios microrganismos invasores. Esses compostos são chamados de elicitores, que é conceituado como toda molécula capaz de ativar mecanismos de defesa em plantas, os quais incluem poli e oligossacarídeos, glicoproteínas, glicopeptídeos, lipopolissacarídeos e lipooligossacarídeos. Além destas macromoléculas, outras moléculas menores como o ácido salicílico e o metil jasmonato são capazes de ativarem respostas de defesa em plantas (ALVARES, 2000; RAO et al., 2000; SHIBUYA; MINAMI, 2001; SILIPO et al., 2005).

\subsubsection{Oligossacarídeos e polissacarídeos}

A degradação das paredes celulares pode resultar na produção de fragmentos de moléculas biologicamente ativas, denominadas de oligossacarinas, que podem estar envolvidas nas respostas de defesa ou de desenvolvimento (expansão celular). Algumas das funções fisiológicas das oligossacarinas incluem estimulação da síntese de fitoalexinas (compostos de baixa massa molecular com atividade microbicida), do "burst" oxidativo, da síntese de etileno, da despolarização da membrana, da indução de proteínas relacionadas à patogênese (tais como quitinases e glucanases) e outros sinais locais e sistêmicos (JOHN et al., 1997). 
Uma interessante característica dos oligossacarídeos que exibem resposta de defesa é o baixo grau de especificidade estrutural referente ao tamanho do polímero (ALDINGTON, 1991). Entretanto, unidades específicas dentro da estrutura do oligossacarídeo são requeridas para exercerem a sua atividade de defesa (NAVAZIO, 2002). Isso torna possível que muitos outros tipos de fragmentos de polissacarídeos da parede celular das plantas exerçam uma resposta de defesa nas células (VORWERK; SOMERVILLE, S.; SORMEVILLE, C., 2004).

Os oligossacarídeos derivados de fungos e os polissacarídeos provenientes de parede celular de plantas são classes bem caracterizadas de elicitores que, em determinados casos, podem induzir respostas de defesa em baixas concentrações, da ordem de nmol/L. Devido a sua bem caracterizada natureza química e à presença de uma alta percepção destas moléculas pelas plantas, alguns destes elicitores têm sido amplamente utilizados como modelos para o estudo no qual tenta-se elucidar como as células vegetais reconhecem estes sinais químicos e desencadeiam a ativação de diversos sistemas de defesa. Estes estudos incluem relações de estrutura-atividade das moléculas elicitoras com seus receptores, análise de transdução de sinal em cascata e fatores genéticos e bioquímicos desencadeados pelo reconhecimento do elicitor pela célula vegetal (NURNBERGER et al., 2004; NURNBERGER; SCHEEL, 2001).

Diversos tipos de oligossacarídeos e polissacarídeos que possuem efeitos elicitores têm sido descritos na literatura, tais como oligossacarídeos de $\beta$-glucanas, de quitina e de quitosanas (BARBER; BERTRAM; RIDE, 1989; COSIO et al., 1996; HADWIGER; BECKMAN, 1980; INUI; YAMAGUCHI; 
HIRANO, 1997; KLARZYNSKI et al., 2000), polissacarídeos de pectinas (WALKER-SIMMONS; HADWIGER; RYAN, 1983).

Outros grupos de oligossacarídeos que demonstram atividade elicitora pertencem aos chamados oligogalacturonídeos (OGAs), que são derivados de polissacarídeos pécticos provenientes das paredes celulares das plantas (D'OVIDIO et al., 2004).

Oligogalacturonídeos podem ser gerados a partir da hidrólise ácida de polissacarídeos pécticos ou pela ação de pectinases. Os oligossacarídeos com maior atividade elicitora costumam ter um grau de polimerização (GP) de 10 a 12 (SHIBUYA; MINAMI, 2001). Entretanto, REYMOND e colaboradores (1995) demonstraram a habilidade de OGAs com GP igual ou maior a 20 induzirem fosforilação de proteínas in vitro. Tais resultados indicam que o tamanho ideal de OGAs com capacidade elicitora pode refletir mais na penetrabilidade do OGA do que na especificidade de reconhecimento pelo seu receptor.

As lesões em plantas podem induzir uma cascata de sinais que resultam na síntese de poligalacturonases que, ao hidrolisarem a parede celular da planta, liberam OGAs, os quais podem ativar respostas de defesa (BERGEY et al., 1999). Os oligogalacturonídeos (OGAs) exibem atividades tais como a indução de espécies reativas de oxigênio (EROs), dentro de minutos e a baixas concentrações (SHAW; LONG, 2003). Além disso, foi demonstrado que os OGAs podem induzir à biossíntese de fitoalexinas em cotilédones de soja e em células de cenoura (ISHIGAKI et al., 2004; NOTHNAGEL et al., 1983), inibir proteinases em folhas de tomate (FARMER et al., 1991) e estimular a lignificação em cotilédones de pepino (ROBERTSEN, 1986). 


\subsection{2. Ácido salicílico (AS)}

Muitas evidências sugerem que o ácido salicílico é uma molécula essencial para o desenvolvimento dos dois principais mecanismos de defesa ativados pelas plantas: a reação de hipersensibilidade $(\mathrm{RH})$ e a resistência sistêmica adquirida (RSA). Plantas transgênicas que expressam a enzima salicilato hidroxilase não são capazes de acumular AS e, conseqüentemente, não desenvolvem RH e RSA (DELANEY et al., 1994).

O ácido salicílico é biossintetizado por duas vias diferentes: a partir do corismato, pela via do isocorismato (Figura 6) e através da via dos fenilpropanóides (Figura 7) (LEE; LÉON; RASKIN, 1995; SCHINEIDER et al., 1996). As pesquisas envolvendo a via do corismato mostraram que a expressão de duas enzimas que catalisam esta reação, isocorismato sintase 1 (ICS1) e isocorismato piruvato liase 1 (IPL1) em tabaco e Arabdopsis resultaram em um aumento no acúmulo de AS e conseqüentemente no aumento da resistência destas plantas aos patógenos (MAUCH et al., 2001; VERBERNE et al., 2000). Tem sido proposto que a via dos fenilpropanóides é responsável pela rápida produção de AS associada com a morte celular local característica da resposta de hipersensibilidade. Entretanto, a via do isocorismato é mais importante para sustentar a síntese de AS durante o desenvolvimento da RSA (WILDERMUTH et al., 2001). 




Eritrose-4-Fosfato

\section{GLICÓLISE}

$\downarrow$

Fosfoenolpiruvato

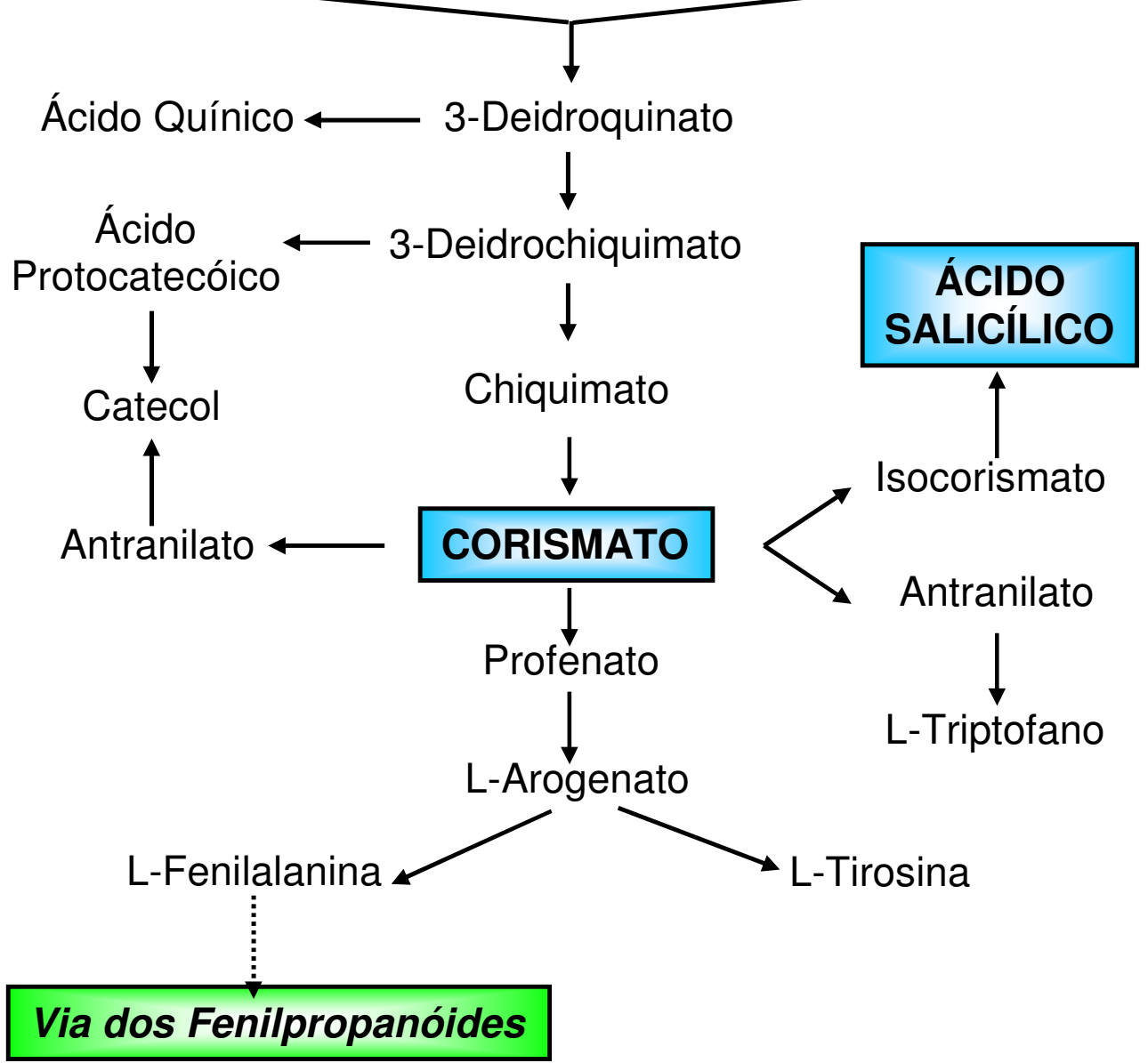

Figura 6. Via metabólica do corismato. O corismato é convertido a isocorismato pela enzima isocorismato sintase 1 (ICS1), sendo que o isocorismato é então transformado em ácido salicílico (adaptado de DE SOUZA, 2005). 


\section{Via dos Fenilpropanóides}

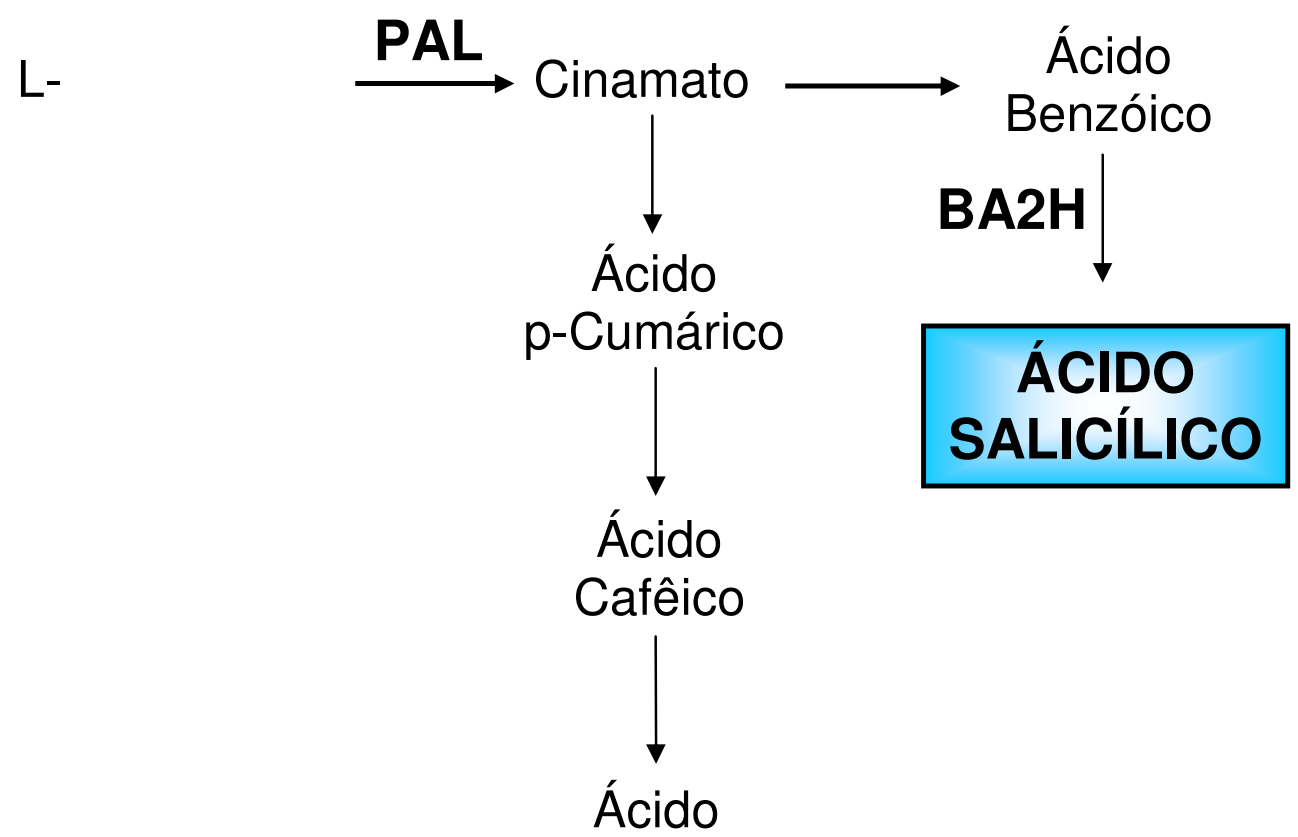

Ferúlic

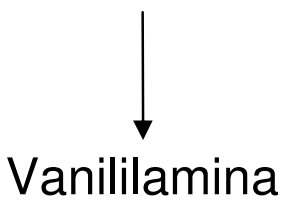

Figura 7. Via metabólica dos fenilpropanóides. PAL refere-se à fenilalanina amônia liase, primeira enzima da via dos fenilpropanóides. BA2H refere-se à enzima ácido benzóico 2-hidroxilase (adaptado de DE SOUZA, 2005). 
Foi verificado que AS aplicado exogenamente acelera a morte celular associada a genes de resistência (genes - R), em cultura de células de soja incubadas com Pseudomonas syringae pv glycinea (SHIRAZU et al., 1997). O ácido salicílico possui papel fundamental em muitos tipos de morte celular, incluindo $\mathrm{RH}$, possivelmente, relacionado à inibição das funções mitocondriais provocada pelo AS (XIE; CHEN, 1999). Alguns dados bioquímicos sugerem que o AS potencializa a via sinalizadora para $\mathrm{RH}$ por afetar uma etapa precoce sensível a fosforilação, precedente a geração de sinais, incluindo aqueles derivados do "burst" oxidativo (ALVARES, 2000).

Embora a ativação de resistência mediada por genes $\mathrm{R}$ seja autônoma para cada célula, os sinais extracelulares ou difusíveis gerados nas células atacadas podem desencadear respostas nas células não infectadas da vizinhança. Um dos sinais difusíveis do AS pode ser $0 \mathrm{H}_{2} \mathrm{O}_{2}$ que, por ser nãocarregado, pode difundir-se através das membranas e reagir a baixas concentrações nas lesões marginais (ALVARES, 2000).

Entretanto, os mecanismos pelo qual o AS ativa os mecanismos de defesa exibidos pelas plantas ainda é objeto de especulação.

\subsubsection{Metil jasmonato (MeJA)}

As descobertas de novos tipos de defesas vegetais mostraram que outras duas moléculas também desempenham funções importantes durante o desenvolvimento do processo de resistência observado nas plantas: o etileno e o ácido jasmônico (AJ), além do metil jasmonato (MeJA). Estas defesas alternativas incluem a resistência sistêmica induzida (RSI), desenvolvida através de bactérias 
colonizadoras de raízes, e a resistência à lesão e a herbivoria (DONG et al., 1998). O ataque de insetos às plantas resulta na síntese de ácido jasmônico e de seu derivado, o metil jasmonato, com subseqüente ativação de genes responsáveis pela produção de inibidores de proteinase, levando a resistência sistêmica adquirida (RSI) na planta (DOARES et al., 1995).

O ácido jasmônico e o seu metil éster - metil jasmonato - são reguladores endógenos do crescimento e desenvolvimento de plantas. A síntese destes compostos é estimulada por uma variedade de processos, incluindo lesões, ataque de herbívoros, estresse osmótico e dissecação (SLESAK, E.; SLESAK, M.; GABRYS, 2001).

O AJ é uma molécula sinalizadora chave que carrega informações sobre lesões; e a sua concentração em lesões de plantas aumenta rapidamente. $\mathrm{O}$ ácido jasmônico induz a expressão de genes de defesa de plantas responsáveis pela síntese de proteínas específicas induzidas por jasmonatos e pela síntese de metabólitos diretamente envolvidos em resistência de plantas como, por exemplo, glicosinolatos. Algumas respostas similares são induzidas nas plantas pelo MeJA, o qual tem um papel chave na comunicação inter-plantas e na indução de resistência contra herbívoros (SLESAK, E.; SLESAK, M.; GABRYS, 2001).

Existem alguns estudos mostrando o envolvimento de metil jasmonato na reação de hipersensibilidade. ANDI e colaboradores (2001) mostraram que MeJA inibir respostas de defesa induzidas por harpina, uma proteína elicitora isolada de diversos patógenos, tais como a geração de $\mathrm{H}_{2} \mathrm{O}_{2}$ e a expressão de gene codificadores para a PAL em cultura de células em suspensão de tabaco. 
Foi proposta uma via sinalizadora para a síntese do ácido jasmônico a partir do ataque de herbívoros (Figura 8) (OROZCO-CÁRDENAS; NARVÁESVÁSQUES; RYAN, 2001).

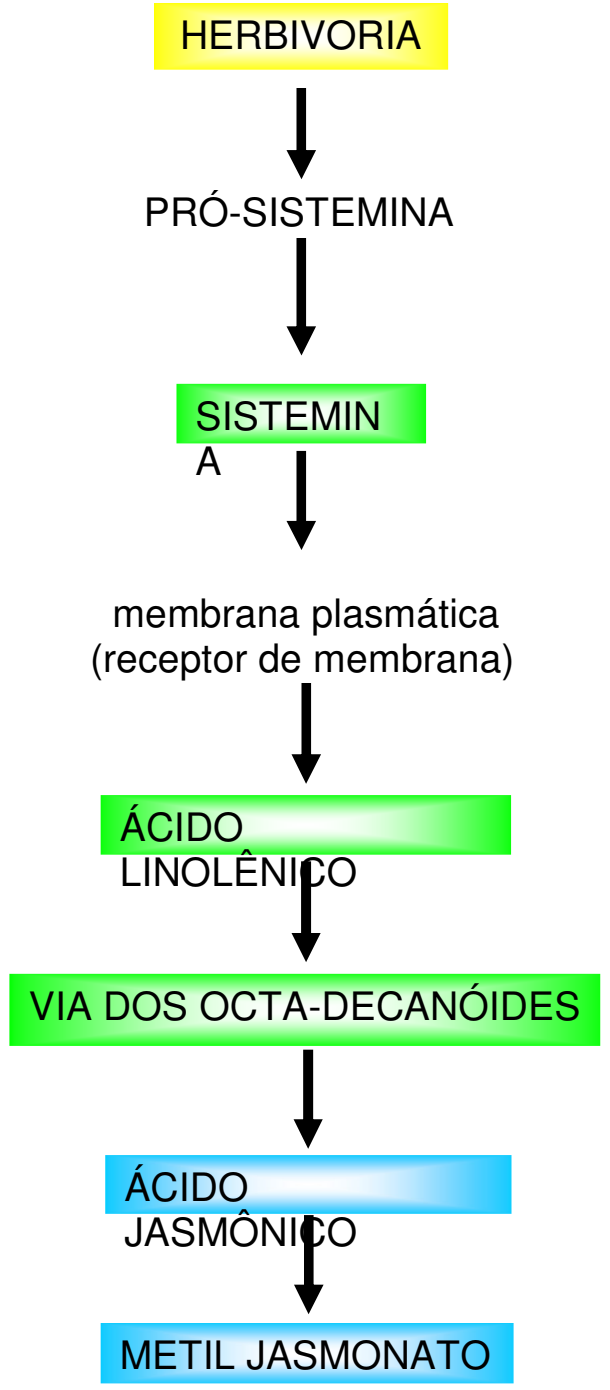

Figura 8. Via sinalizadora para a síntese do ácido jasmônico. Nesta via a sistemina inicia uma cascata de eventos intracelulares resultante da ativação de uma fosfolipase citoplasmática que libera ácido linolênico das membranas. O acido linolênico é convertido a ácido jasmônico através da via dos octa-decanóides que, por último, pode 
ser convertido a metil jasmonato (adaptado de OROZCO-CÁRDENAS; NARVÁESVÁSQUES; RYAN, 2001).

\subsection{Estudos com Rubus fruticosus (amora-preta)}

Ensaios biológicos em células ou protoplastos de Rubus fruticosus têm sido bastante utilizados, tanto em investigações sobre os sistemas de defesa de plantas quanto em experimentos para o estudo do crescimento e desenvolvimento celular das mesmas. LIÉNART, GAUTIER e DRIGUEZ (1990), e mais tarde, DINAND e colaboradores (1997), estudaram o efeito de açúcares como um indutor abiótico em cultura de células de $R$. fruticosus, observando as atividades das enzimas laminarinase, xilanase e quitinase. A ativação de hidrolases é uma forma de defesa bioquímica das plantas. Os polissacarídeos podem ser uma das partes do sistema sinalizador, o qual promove a transcrição e tradução de proteínas de estresse.

VARGAS-RECHIA e colaboradores (1998) isolaram oligossacarídeos de xiloglucana extraídos das sementes de Hymenaea courbaril e verificaram que um octassacarídeo reduzido (XXLGol) em concentrações nanomolares, na presença ou não de ácido 2, 4-diclorofenoxiacético (2,4-D), é capaz de modular a resposta à $\alpha$-L-fucosidase em células ou protoplastos de $R$. fruticosus.

Sabe-se que as plantas reagem à penetração do fungo Fusarium sp. acumulando calose e outros componentes da parede celular. Sendo assim, NITA-LAZAR, CHEVOLOT e LIÉNART (1998) investigaram como O-glicanas extraídas de glicoproteínas de Fusarium sp, podem agir como moléculas sinalizadoras. Estes autores verificaram que incubando uma fração de O-glicana, 
com protoplastos de $R$. fruticosus, houve uma indução da atividade do complexo fenilalanina amônio liase (PAL) (NITA-LAZAR et al., 2002). Além disso, observaram que a glicoproteína de Fusarium sp. é elicitor de EROs neste sistema (NITA-LAZAR et al., 2004).

PATIER e colaboradores (1995) mostraram que as $\beta$-1,3-glucanas, que são os componentes principais de herbicidas líquidos, são capazes de elicitar D-glicanases ( $\beta$-1,3-glucanase e $\alpha$-amilase) em células de $R$. fruticosus. Esse mesmo estudo demonstrou que uma $\kappa$-carragenana elicita a atividade da enzima $\beta$-1,3-glucanase no mesmo sistema de células em suspensão.

\subsection{Ramnoglucuronogalactana (F-I)}

O polissacarídeo ramnoglucuronogalactana $(F-I)$ foi isolado e purificado do tegumento das sementes de Chorisia speciosa St. Hil (conhecida como paineira), no Laboratório de Carboidratos Vegetais da Universidade Federal do Paraná (UFPR). F-I é composto por ramnose, galactose e ácido glucurônico, na proporção molar de 25:44:31 e possui massa molecular de 2,77 x $10^{6}$ (BELESKICARNEIRO et al., 1996; BELESKI-CARNEIRO; GANTER; REICHER, 1999; BELESKI-CARNEIRO; SUGUI; REICHER, 2002).

BELESKI-CARNEIRO, SUGUI e REICHER (2002) utilizaram este polímero em testes de atividade biológica, em folhas de milho (Zea mays) infectadas com o fungo causador da antracnose, Colletotrichum graminicola. Os resultados sugeriram que F-I interferiu na adesão do fungo $C$. graminicola em folhas de Z. mays. 
Estudos recentes em nosso laboratório demonstraram que F-I é capaz de induzir atividade de proteínas relacionadas à patogênese (proteínas-RP), tais como a quitinase e a $\beta$-1,3-glucanase, além de induzir ao acúmulo de compostos fenólicos em cultura de células de $R$. fruticosus (DE SOUZA, 2005).

O acúmulo de AS intracelular, na presença de F-I extracelular ocorreu de forma transitória. Este fato levou a acreditar na presença de receptor de membrana para F-I. Também foi conseguida, pela primeira vez, uma indução da atividade da poligalacturonase (PG) pelo AS. Os estudos do efeito elicitor de AS e F-I demonstraram que estes compostos são potenciais indutores de resistência em amora-preta ( $R$. fruticosus) (DE SOUZA, 2005).

Os dados obtidos em nosso laboratório com F-I, em cultura de células em suspensão de Rubus fruticosus, nos levaram a propor neste projeto o estudo de respostas de hipersensibilidade $(\mathrm{RH})$ sobre a parede celular mediada por F-I, bem como por ácido salicílico e metil jasmonato, conhecidos elicitores de respostas de defesa em plantas. 


\subsection{Objetivo geral}

O objetivo geral deste trabalho foi estudar o efeito do ácido salicílico (AS), metil jasmonato (MeJA) e ramnoglucuronogalactana do tegumento das sementes de Chorisia speciosa St. Hil (F-I) em respostas de hipersensibilidade em cultura de células de Rubus fruticosus.

\subsection{Objetivos específicos}

Nossos objetivos específicos foram:

1 - padronização das condições experimentais para a determinação da produção de EROs;

2 - determinação do efeito da elicitação com F-I, MeJA, AS e suas misturas sobre a produção de EROs;

3 - determinação do efeito da elicitação com F-I, MeJA, AS e as misturas sobre a produção de $\mathrm{H}_{2} \mathrm{O}_{2}$;

4 - dosagem de açúcar redutor e proteína total, liberados para o meio extracelular, de células de $R$. fruticosus quando da elicitação com AS, MeJA, F-I e as misturas;

5 - padronização das condições experimentais para a análise dos efeitos de $\mathrm{RH}$ sobre a parede celular;

6- análise da composição monossacarídica da parede celular após elicitação com AS, MeJA, F-I e as misturas; 
7 - Análise por CLAE dos componentes da parede celular liberados no meio extracelular (fração P) após o ensaio de elicitação. 


\subsection{Equipamentos}

- Agitador AS 850 (BIOLAFITTE);

- Câmara de Neubauer (BIOBLOCK);

- Microscópio óptico (OLYMPUS CH2);

- Sonicador Vibra Cell (SONIC \& MATERIALS Inc.);

- Centrífuga BECKMAN J2 - 21;

- Fluorímetro F - 4500 (HITACHI);

- Rotaevaporador rotativo TE 120 (TECNAL);

- CLAE modelo 510 WATERS e detector de índice de refração modelo R 401 WATERS (MILLIPORE ${ }^{\circledR}$ );

- Cromatógrafo a Gás modelo 37 e integrador-processador modelo CG-200 (INSTRUMENTOS CIENTÍFICOS CG LTDA);

- ELISA modelo EIAmulti-well reader (SIGMA ${ }^{\circledR}$ DIAGNOSTICS);

- Espectrofotômetro DU ${ }^{\circledR}-70$ (BECKMAN).

\subsection{Soluções e reagentes}

- Todos os reagentes citados foram comprados da marca SIGMAALDRICH; exceto o reagente utilizado para a quantificação de proteínas totais, que pertence à marca BIORAD. 


\subsubsection{Ramnoglucuronogalactana (F-I) de Chorisia speciosa}

- O polissacarídeo ramnoglucuronogalactana (F-I) foi obtido pela extração aquosa do tegumento das sementes de $C$. speciosa, sendo então purificado. Sua estrutura foi determinada no Laboratório de Química de Carboidratos Vegetais da UFPR, sob a responsabilidade da Dra. Fany Reicher (BELESKI-CARNEIRO; SUGUI; REICHER, 2002), cedido ao nosso laboratório em um processo de colaboração de pesquisa, já estabelecido há alguns anos.

\subsubsection{Meio de suspensão celular (MSC)}

- Citrato de sódio 50 mmol/L, pH 5,9;

- Sacarose $2 \%(\mathrm{~m} / \mathrm{v})$

- EGTA $4 \mathrm{mmol} / \mathrm{L}$;

- $\mathrm{MgCl}_{2} 3 \mathrm{mmol} / \mathrm{L}$

- $\mathrm{CaCl}_{2}$ 0,06 mmol/L.

\subsubsection{Tampão citrato}

- Citrato de sódio 0,1 mol/L, pH 5,9;

- Sacarose 2\% (m/v).

\subsubsection{Tampão tris-HCl}

- Tris - HCl 50 mmol/L, pH 7,2. 


\subsubsection{Meio de cultura de Heller}

O meio de cultura de HELLER (1953) consiste de macroelementos, ou seja, elementos que estão em grande quantidade no meio (cálcio, potássio, magnésio, sódio e fósforo) e microelementos, que estão em pequenas quantidades (alumínio, cobre, boro, manganês, níquel e zinco), ambos na forma de sais (Tabela 1), além de ferro $\left(\mathrm{FeCl}_{3} .6 \mathrm{H}_{2} \mathrm{O} 1 \mathrm{mg} / \mathrm{L}\right)$, vitamina (cloridrato de tiamina $1 \mathrm{mg} / \mathrm{L}$ ) e glucose $50 \mathrm{~g} / \mathrm{L}$ como fonte de carbono.

Tabela 1 - Quantidades de macro e microelementos utilizados para preparação do meio de cultura de Rubus fruticosus.

\begin{tabular}{cccc}
\hline Macroelementos & Quantidade (mg/L) & Microelementos & Quantidade (mg/L) \\
\hline $\mathrm{CaCl}_{2}$ & 56,520 & $\mathrm{AlCl}_{3} \cdot 6 \mathrm{H}_{2} \mathrm{O}$ & 0,054 \\
$\mathrm{KCl}$ & 750,000 & $\mathrm{CuSO}_{4} \cdot 5 \mathrm{H}_{2} \mathrm{O}$ & 0,030 \\
$\mathrm{MgSO}_{4}$ & 121,560 & $\mathrm{H}_{3} \mathrm{BO}_{3}$ & 1,000 \\
$\mathrm{NaNO}_{3}$ & 600,000 & $\mathrm{KI}$ & 0,010 \\
$\mathrm{NaH}_{2} \mathrm{PO}_{4}$ & 108,700 & $\mathrm{MnSO}_{4} \cdot \mathrm{H}_{2} \mathrm{O}$ & 0,075 \\
& & $\mathrm{NiCl}_{2} \cdot 6 \mathrm{H}_{2} \mathrm{O}$ & 0,030 \\
& & $\mathrm{ZnSO}_{4} \cdot 7 \mathrm{H}_{2} \mathrm{O}$ & 1,000
\end{tabular}

\subsection{Preparação das células cultivadas}

Foram utilizadas células de $R$. fruticosus cultivadas in vitro por técnica de suspensão celular (HUSTACHE; MOLLARD ; BARNOUD, 1975). As células foram cultivadas em meio HELLER (1953), sob agitação, a $25^{\circ} \mathrm{C}$, com fotoperíodo de 12 
horas. As células foram retiradas, do meio de cultura, na fase exponencial de crescimento, 18 dias de replicação, filtradas em membrana de $100 \mu \mathrm{m}$ e suspensas MSC. As células foram deixadas em repouso durante duas horas antes de iniciar qualquer um dos experimentos.

\subsubsection{Contagem e viabilidade celular}

A contagem das células foi realizada em câmara de Neubauer com utilização de microscópio óptico (aumento de 40X) e teve sua viabilidade analisada através do corante azul de Evans (KANAI; EDWARDS, 1973). Foram adicionados $20 \mu \mathrm{L}$ de azul de Evans $1 \%(\mathrm{~m} / \mathrm{v})$ a $200 \mu \mathrm{L}$ de suspensão de células e a porcentagem de células viáveis foi feita pelo número de células não coradas entre 100 contadas. Para os experimentos foi considerada uma viabilidade mínima de $90 \%$. A seguir as células foram preparadas para os ensaios de elicitação.

\subsection{Detecção de espécies reativas de oxigênio (EROs)}

\subsubsection{Padronização das condições experimentais para a detecção de espécies reativas de oxigênio}

As EROs foram determinadas através do método descrito por LEE e colaboradores (1999) e MURATA e colaboradores (2001), utilizando o diacetato de 2,7-diclorofluoresceína ( $\left.\mathrm{H}_{2} \mathrm{DCF}-\mathrm{DA}\right)$, padronizado para o sistema biológico utilizado.

As células de $R$. fruticosus $\left(8 \times 10^{4}\right.$ cél. $\left./ \mathrm{mL}\right)$ em $2 \mathrm{~mL}$ de meio reacional, sem elicitação prévia ou com elicitação prévia de 1 e 24 h, após 2 h de repouso. Em seguida, as células foram encubadas com $\mathrm{H}_{2}$ DCF-DA, em concentrações até 
$10 \mu \mathrm{mol} / \mathrm{L}$, durante períodos de até 30 minutos. Após, foram submetidas à cinética de liberação de EROs utilizando-se F-I 1000 nmol/L como elicitor e a fluorescência foi medida em fluorímetro Hitachi F-4500 com comprimentos de onda de excitação e emissão de 503 e 529 nm e fendas de 5 e 10 nm, respectivamente, sob $700 \mathrm{~V}$ de voltagem. O mesmo experimento de elicitação descrito acima foi realizado sem incubação prévia com $\mathrm{H}_{2}$ DCF-DA. Água deionizada foi utilizada como controle da elicitação.

\subsubsection{Análise do efeito de elicitores e de misturas de elicitores em diferentes tempos de elicitação}

As amostras foram mantidas nas mesmas condições do experimento anterior, sendo analisado apenas um elicitor por vez ou misturas de elicitores F-I+AS, F-I+MeJA e AS+MeJA nas concentrações finais, no meio reacional, de $1000 \mathrm{nmol} / \mathrm{L}$ de cada elicitor, em tempos de elicitação de 15, 30, 45 e 60 minutos. Os controles foram preparados com água deionizada para F-I, AS e F-I + AS; DMSO para MeJA e água deionizada com dimetilsulfóxido para F-I+MeJA e AS+MeJA.

Os efeitos foram expressos: a) em relação à intensidade de fluorescência pelo tempo; b) como a relação da tangente das curvas de fluorescência de células tratadas com elicitores contra os controles (células suspensas em tampão sem efetores) ou também como porcentagem (\%) de fluorescência em relação aos controles. 


\subsection{Detecção do peróxido de hidrogênio $\left(\mathrm{H}_{2} \mathrm{O}_{2}\right)$}

A detecção do $\mathrm{H}_{2} \mathrm{O}_{2}$ foi feita pela sua produção, em um ensaio de elicitação, utilizando o ácido homovanílico (HVA) como a molécula fluorescente que reage, preferencialmente, com o complexo peroxidase $-\mathrm{H}_{2} \mathrm{O}_{2}$ (BARJA, 2002). Células de $R$. fruticosus de 18 dias, $8 \times 10^{4}$ cél. $/ \mathrm{mL}$ em $2 \mathrm{~mL}$ de meio reacional, em tampão citrato, foram elicitadas com F-I, AS, MeJA, F-I + AS, F-I + MeJA e AS + MeJA na concentração de $1000 \mathrm{nmol} / \mathrm{L}$. O meio de reação contendo as células foi acrescido de $8 \mu \mathrm{L}$ de HVA 0,1 mmol/L, encubado por 20 minutos. Em seguida, foi adicionado $9,2 \mu \mathrm{L}$ de HRP (peroxidase de rabanete) $12 \mathrm{Ul} / \mathrm{mL}$. Por último, foram adicionados os elicitores e iniciada a cinética que foi monitorada em fluorímetro Hitachi F-4500, com comprimento de onda de excitação e emissão de 312 e $420 \mathrm{~nm}$, respectivamente, com fendas de emissão de $10 \mathrm{~nm}$ e de excitação de $20 \mathrm{~nm}$, sob $700 \mathrm{~V}$ de voltagem.

\subsection{Ensaios de elicitação}

As células $\left(8 \times 10^{4}\right.$ cél. $\left./ \mathrm{mL}\right)$ em $25 \mathrm{~mL}$ de meio reacional, após repouso por 2 horas, foram suspensas em tampão citrato de sódio na presença dos elicitores ramnoglucuronogalactana de $C$. speciosa $(\mathrm{F}-\mathrm{I})$, ácido salicílico e metil jasmonato, todos na concentração final de $1000 \mathrm{nmol} / \mathrm{L}$, sob agitação, a temperatura ambiente, durante tempos de elicitação de 15 a 60 minutos. $O$ controle do ensaio foi realizado utilizando-se água deionizada ou dimetilsulfóxido (DMSO) como elicitor. Cada elicitação foi realizada em triplicata e as induções foram interrompidas colocando-se as amostra em gelo. A seguir as células foram 
recuperadas por decantação. Um volume conhecido do sobrenadante, $20 \mathrm{~mL}$, foi separado para a dosagem de compostos extracelulares (fração S). Às células foram adicionados $10 \mathrm{~mL}$ de tampão Tris- $\mathrm{HCl} 50 \mathrm{mmol} / \mathrm{L}, \mathrm{pH}$ 7,2, por duas vezes, para lavagem das células. Essa suspensão de células foi posteriormente sonicada, obtendo-se um resíduo (fração P) que foi submetido a análises posteriores.

\subsection{Padronização protocolo para análise dos componentes da parede celular}

Para a análise da parede celular, cada amostra obtida no ensaio de elicitação após as duas lavagens com $10 \mathrm{~mL}$ de tampão Tris- $\mathrm{HCl}$, foi sonicada a $60 \mathrm{~W}$ com 4 pulsos de 20 segundos com intervalos de 30 segundos em banho de gelo. A seguir as amostras foram centrifugadas a $4^{\circ} \mathrm{C}, 12.000 \mathrm{xg}$ por 15 minutos $\mathrm{e}$ os sobrenadantes foram descartados. Os resíduos (fração P) foram submetidos a hidrólise, redução e acetilação, descritos abaixo, para então ser determinada a composição em monossacarídeos, através da cromatografia líquido-gasosa (GLC). 


\subsection{Preparação de amostras para análise da composição monossacarídica da parede celular}

Todos os procedimentos para a análise da composição monossacarídica da parede celular foram realizados em capela de exaustão.

\subsubsection{Hidrólise de Saeman}

A fração $\mathrm{P}$, obtida após sonicação das células de $R$. fruticosus elicitadas com os diferentes indutores, foi pesada. Uma alíquota de $100 \mathrm{mg}$ foi colocada em um tubo de hidrólise em banho de gelo e acrescido $0,5 \mathrm{~mL}$ de $\mathrm{H}_{2} \mathrm{SO}_{4} 72 \%$ (v/v), mantido por 2 horas em gelo com agitação periódica. Após este tempo, o ácido foi diluído para 5\% e o sistema mantido 18 horas a temperatura ambiente. A seguir foi adicionado $\mathrm{BaCO}_{3}$ até a neutralização, a amostra foi filtrada para ser submetida à redução (SAEMAN et al., 1954).

\subsubsection{Redução de Wolfrom e Thompson}

As amostras hidrolisadas, contendo os monossacarídeos livres, foram reduzidas com $\mathrm{NaBH}_{4}$, em $\mathrm{pH}$ 9, com agitação durante 1 hora. A seguir, as amostras foram mantidas a temperatura ambiente por 48 horas. Após esse período foram neutralizadas com ácido acético glacial, concentradas até a secura, lavadas sucessivamente com $\mathrm{H}_{2} \mathrm{O}$ e metanol para eliminar o excesso de ácido acético, e o tetraborato de metila, respectivamente, e as amostras foram evaporadas até a secura. Para completar a secagem, as amostras foram 
colocadas em uma pistola de secagem contendo pentóxido de fósforo, sob etanol em refluxo (WOLFROM; THOMPSON, 1963a).

\subsubsection{Acetilação de Wolfrom e Thompson}

As frações $P$ reduzidas, contendo os alditóis, foram ressuspensas em $1 \mathrm{~mL}$ de piridina e acetiladas com a adição de $1 \mathrm{~mL}$ de anidrido acético em tubos hermeticamente vedados. O sistema foi deixado à temperatura ambiente, 18 horas. A seguir houve a interrupção da reação de acetilação por adição de gelo picado. Em seqüência, adicionou-se $2 \mathrm{~mL}$ de clorofórmio, com agitação ocasional por 2 horas à temperatura ambiente, para extração dos acetatos de alditóis. O excesso de piridina foi eliminado por lavagens sucessivas com $\mathrm{CuSO}_{4} .5 \mathrm{H}_{2} \mathrm{O} 5 \%$ e água. A fase clorofórmica, contendo os acetatos de alditóis, foi transferida para tubos de hemólise e seca (WOLFROM; THOMPSON, 1963b).

\subsubsection{Análise e quantificação por GLC}

Para a análise e quantificação da composição monossacarídica da parede celular em cromatografia líquido-gasosa (GLC), as amostras foram dissolvidas em 2 gotas de clorofórmio e aplicadas alíquotas $0,5 \mu \mathrm{L}$ em cromatógrafo a Gás modelo 37 com detector de ionização de chama a $250^{\circ} \mathrm{C}$, utilizando-se nitrogênio como gás de arraste, fluxo de $30 \mathrm{~mL} / \mathrm{min}$. Uma coluna empacotada com $3 \%$ de OV-225 sobre gá chrom Q de 100 a 200 mesh, 170 x 2 (d.i.), mantida a temperatura constante de $190^{\circ} \mathrm{C}$, com vaporizador a $230^{\circ} \mathrm{C}$. A quantificação dos 
produtos analisados foi feita utilizando um integrador-processador modelo CG-200.

\subsection{Dosagem de açúcar redutor pelo método do ferricianeto}

O método consistiu em reagir $100 \mu \mathrm{L}$ das amostras sobrenadantes (fração S), padrão (galactose até $250 \mu \mathrm{g} / \mathrm{mL}$ ) e o branco (água), em triplicata, com $3 \mathrm{~mL}$ do Reagente de Ferricianeto (KIDBY; DAVIDSON, 1973), sob aquecimento a $100^{\circ} \mathrm{C}$ durante 7 minutos. Em seguida, resfriou-se em gelo e realizou-se a leitura em espectrofotômetro a $420 \mathrm{~nm}$.

\subsection{Dosagem de proteína total pelo método de Bradford}

A determinação de proteínas foi realizada por microensaio em placa, pelo método de BRADFORD (1976). Alíquotas de $160 \mu \mathrm{L}$ de cada amostra sobrenadante (fração S), padrão (BSA de 0,25 a $25 \mu \mathrm{g} / \mathrm{mL}$ ) e branco (água), em triplicata, foram colocadas em placa ELISA, adicionou-se $40 \mu \mathrm{L}$ do reagente de cor, Comassie Brilliant Blue "G". O meio reacional de $200 \mu \mathrm{L}$ foi agitado e a placa foi incubada à temperatura ambiente por 5 minutos. Por último, o conteúdo da placa foi lido em aparelho de ELISA, no comprimento de onda de $600 \mathrm{~nm}$. 


\subsection{Isolamento dos componentes extracelulares das células elicitadas com os elicitores, suas misturas e os controles por cromatografia líquida de alta eficiência (CLAE)}

As frações dos meios extracelulares foram filtradas em membranas de nitrato de celulose $(0,45 \mu \mathrm{m})$, aplicadas em coluna analítica de fase reversa $\mathrm{C} 18$ modelo Bio-Sil C18 HL 90-5 S (25 x 0,46 cm) em cromatógrafo modelo 510 WATERS e eluídas com mistura metanol:água, $5 \%$ de metanol, fluxo $0,8 \mathrm{~mL} / \mathrm{min}$ e detecção por índice de refração.

\subsection{Cromatografia em camada delgada (CCD)}

Alíquotas de $5 \mu \mathrm{L}$ das frações sobrenadantes (S), do ensaio de elicitação de $R$. fruticosus, foram aplicadas em placa de sílica (cromatofolhas de silica gel DC-Alufolien $(A L)$ Kieselgel $60 F_{254}$ ), com dimensões de $20 X 20 \mathrm{~cm}$ e espessura de 0,2 mm. A fase móvel foi composta por uma mistura de butanol:etanol: $\mathrm{H}_{2} \mathrm{O}$ 5:3:2 (v/v/v). A corrida foi revelada com uma mistura de $\mathrm{H}_{2} \mathrm{SO}_{4}$ :etanol 9:1 (v/v), seguido de aquecimento em estufa a $100^{\circ} \mathrm{C}$. O padrão utilizado foi uma mistura MDTP de monossacarídeo de glucose, dissacarídeo de maltose, tetrassacarídeo e pentassacarídeos de glucose na concentração de $2 \mathrm{mg} / \mathrm{mL}$.

\subsection{Análise estatística dos resultados}

A análise de variância (ANOVA) foi realizada através do teste de Tukey (software Prism 4.0), não paramétrico, e foram considerados resultados 
estatisticamente significativos àqueles onde $p<0,05$. As dosagens de produção de EROs, açúcar redutor e de proteína total da fração sobrenadante (fração S) foram realizadas através das medidas de 6 ensaios de elicitação independentes. Os resultados foram expressos através da mediana dos dados obtidos destes ensaios. A quantificação do $\mathrm{H}_{2} \mathrm{O}_{2}$ seguiu o mesmo padrão de análise das dosagens anteriores, porém foram utilizados 4 ensaios de elicitação para a dosagem deste composto. Os gráficos e a análise estatística foram obtidos com o auxílio do software Prism 4.0 para Windows.

\subsection{Padronização para os ensaios de elicitação das células de R. fruticosus}

Nossos estudos abordaram a indução da produção de espécies reativas de oxigênio (EROs), a produção de peróxido de hidrogênio $\left(\mathrm{H}_{2} \mathrm{O}_{2}\right)$ e os efeitos sobre a parede celular através da liberação de açúcares e proteínas para o meio extracelular em células de Rubus fruticosus de 18 dias. Os elicitores analisados foram um polissacarídeo ácido, a ramnoglucuronogalactana (F-I) extraída de sementes de Chorisia speciosa, o ácido salicílico (AS) e o metil jasmonato (MeJA), em concentrações até 1000 nmol/L.

Os protocolos experimentais para o estudo dessas respostas foram padronizados para o nosso modelo experimental, como está demonstrado na Figura 9. 


\section{ENSAIOS DE ELICITAÇÃO}

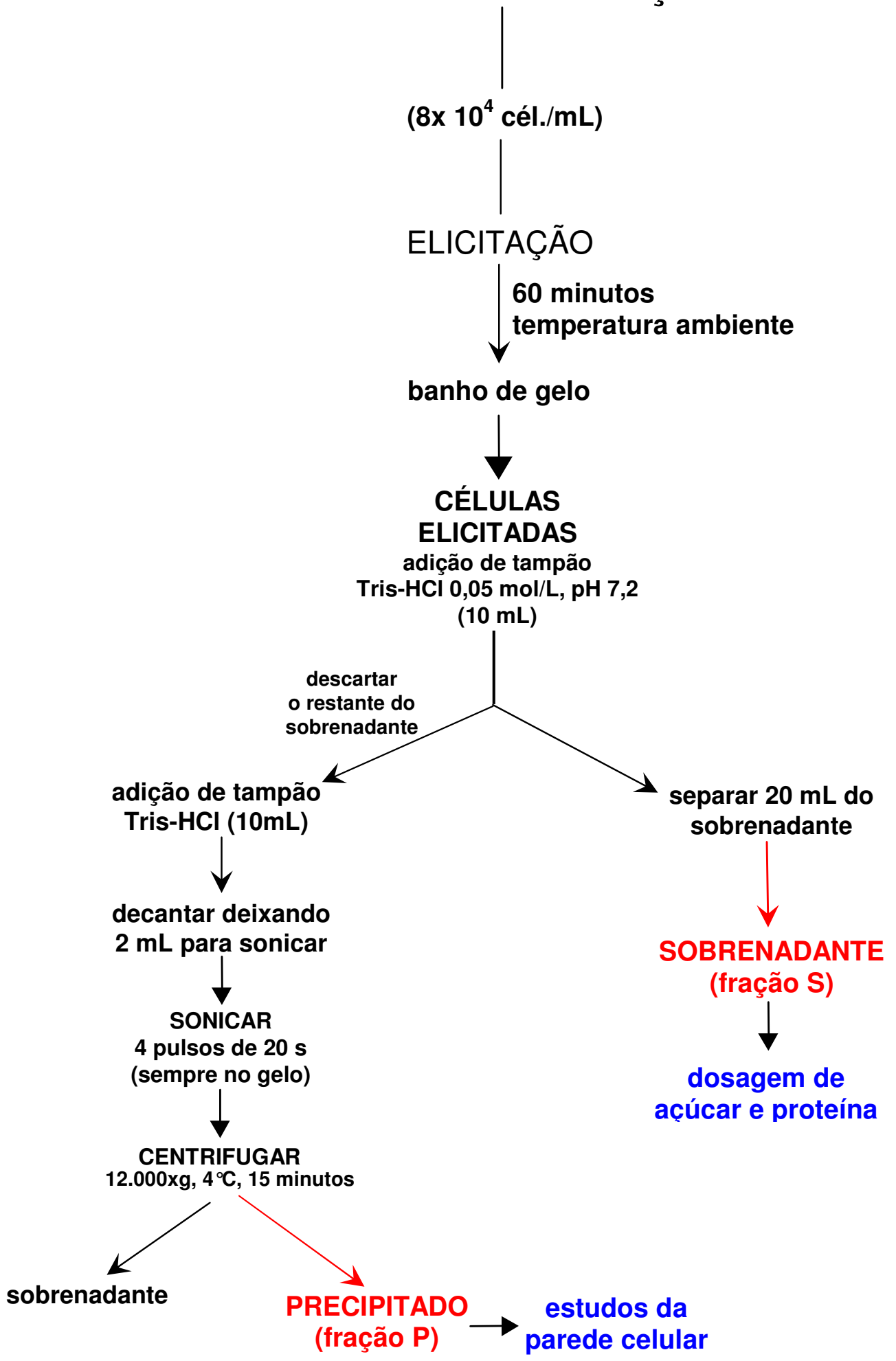

Figura 9. Fluxograma do protocolo experimental para os ensaios de elicitação com F-I, MeJA, AS e suas misturas para determinação das respostas de $\mathrm{RH}$, em células de 18 dias de Rubus fruticosus. 


\subsection{Padronização das condições experimentais para a detecção de espécies reativas de oxigênio}

Os experimentos iniciais, para a detecção da liberação de EROs, foram realizados com o objetivo de padronizar os parâmetros envolvidos nesses experimentos. Sendo assim, esses ensaios foram desenvolvidos com um número pequeno de repetições, uma ou duas vezes, para que, assim que as condições experimentais estivessem satisfatórias, resultados experimentais confiáveis pudessem ser analisados estatisticamente.

O primeiro experimento teve o objetivo de encontrar a melhor concentração da sonda para a leitura de emissão de fluorescência e verificar a necessidade de incubação das células com a sonda antes da realização dos experimentos de indução com os elicitores.

As células de $R$. fruticosus de 18 dias $\left(8 \times 10^{4}\right.$ cél $/ \mathrm{mL}$ em $\left.2 \mathrm{~mL}\right)$ foram submetidas a ensaios de elicitação com F-I 1000 nmol/L, utilizando incubação (30 minutos) ou não com $\mathrm{H}_{2}$ DCF-DA (10 $\left.\mu \mathrm{mol} / \mathrm{L}\right)$. Podemos verificar que as amostras incubadas com $\mathrm{H}_{2}$ DCF-DA $10 \mu \mathrm{mol} / \mathrm{L}$ apresentaram maior detecção de EROs do que as amostras que não sofreram incubação (Figura 10). Além disso, as diferenças na liberação de EROs entre a amostra controle (água) e a amostra com elicitor, F-I, é quase inexistente nas amostras sem incubação. Entretanto, nas amostras com incubação com $\mathrm{H}_{2}$ DCF-DA, as diferenças de EROs liberadas aparecem desde o início das medidas. Esses resultados mostraram que pode haver diferenças de liberação de EROs entre as amostras elicitadas e as controles e que há necessidade de incubação com o $\mathrm{H}_{2} \mathrm{DCF}-\mathrm{DA}$. 
Os valores de detecção de EROs observados para elicitação com F-I foram superiores a faixa de maior sensibilidade de detecção do aparelho (0 a 5000 URF, unidades relativas à fluorescência). Isso mostrou que a concentração de $10 \mu \mathrm{mol} / \mathrm{L}$ de $\mathrm{H}_{2}$ DCF-DA, foi alta para o experimento realizado (Figura 10). Esses resultados nos levaram a diminuir a concentração final de $H_{2}$ DCF-DA para $2 \mu \mathrm{mol} / \mathrm{L}$ nos experimentos posteriores, assim como o tempo de incubação de 30 para 20 minutos para esta molécula.

Verificamos que a incubação com $\mathrm{H}_{2}$ DCF-DA é necessária para mostrar as diferenças nos valores de EROs entre as amostras não elicitadas (controle) e as amostras elicitadas (no caso, com F-I). Para apresentar fluorescência, a sonda precisa de um tempo para penetrar na célula, para dessa forma ser clivada pelas esterases endógenas e liberar seu fragmento $\mathrm{H}_{2}$ DFC impermeável. $\mathrm{O}_{2} \mathrm{DFC}$, que se acumula na célula, funciona como um "indicador" de EROs convertendo-se por oxidação na sua forma fluorescente DFC (LEE et al., 1999). 


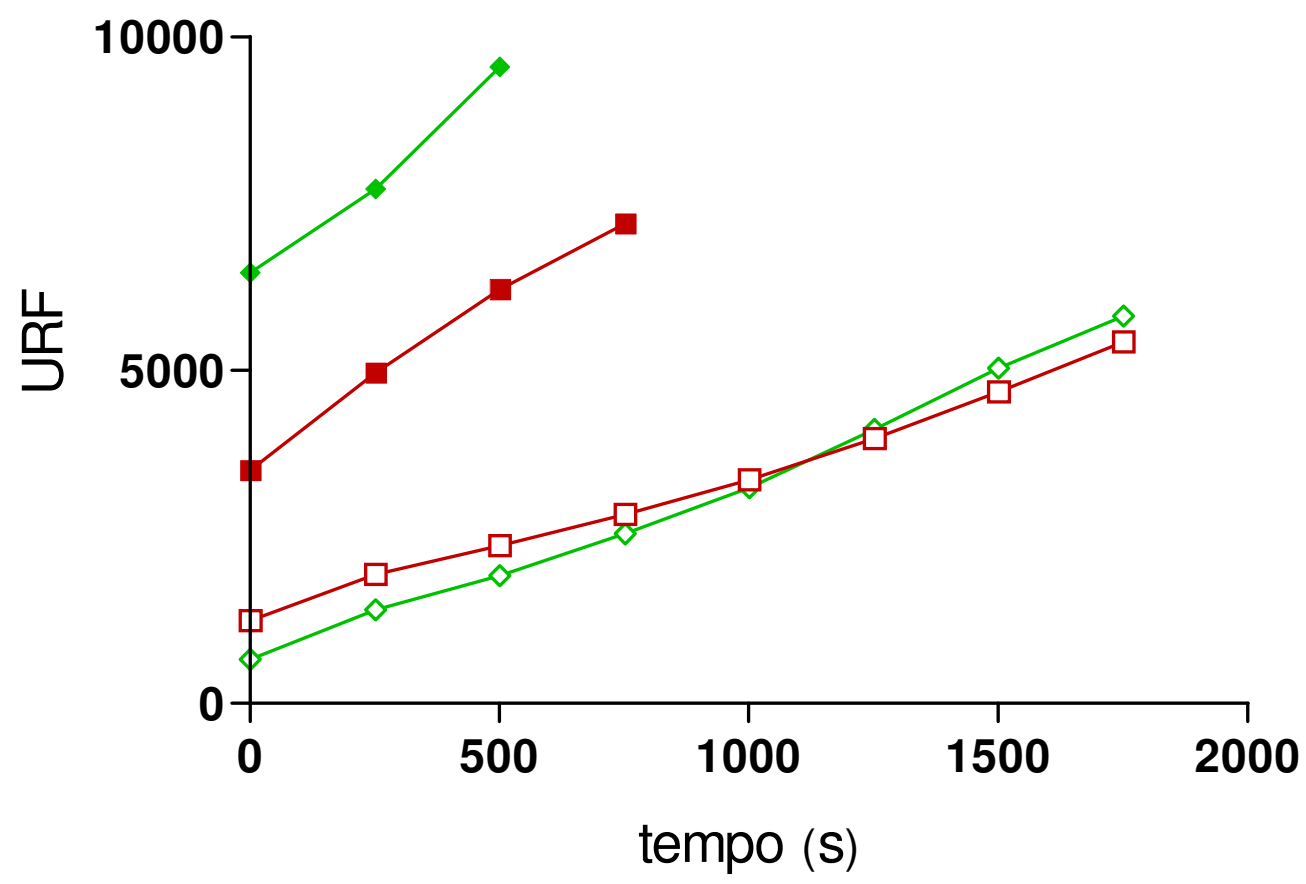

Figura 10. Estudos de incubação com $\circ \mathrm{H}_{2}$ DCF-DA em resposta a liberação de EROs em células de Rubus fruticosus; células de 18 dias; $8 \times 10^{4}$ cél./mL em $2 \mathrm{~mL}$ de amostra; incubação de 30 minutos com $\mathrm{H}_{2}$ DCF-DA $10 \mu \mathrm{mol} / \mathrm{L}$; F-I [1000 nmol/L]. O grupo contendo apenas $\mathrm{H}_{2}$ DCF-DA não apresentou resposta a liberação de EROs. ( $)$ F-I com incubação com $\mathrm{H}_{2}$ DCF-DA ( $\left.n=2\right)$; $(\square)$ controle $\left(\mathrm{H}_{2} \mathrm{O}\right)$ com incubação com $\mathrm{H}_{2}$ DCF-DA $(n=2)$; $(\vartheta)$ F-I sem incubação com $\mathrm{H}_{2}$ DCF-DA $(n=2)$; $(\square)$ controle $\left(\mathrm{H}_{2} \mathrm{O}\right)$ sem incubação com $\mathrm{H}_{2}$ DCF-DA $(\mathrm{n}=2)$; fluorímetro Hitachi F-4500 com $\lambda$ (ex/em):(503/529 nm), fendas $(5 / 10 \mathrm{~nm})$ e voltagem $(700 \mathrm{~V})$. 
O primeiro experimento foi realizado em amostras que não foram submetidas a uma elitação prévia com o elicitor F-I. Após os resultados de padronização com a sonda $\left(\mathrm{H}_{2} \mathrm{DCF}-\mathrm{DA}\right)$, foi de interesse estudar se, com elicitação prévia, haveria alteração no perfil da curva de fluorescência em resposta a liberação de EROs de cultura células de $R$. fruticosus. O experimento anterior correspondia a liberação de EROs nos primeiros instantes de contato do elicitor com as células.

Assim, o segundo experimento foi desenvolvido para verificar a necessidade de uma elicitação prévia com o elicitor antes da leitura da liberação de EROs.

Os resultados obtidos na Figura 11 com as células elicitadas previamente, com F-I, durante $1 \mathrm{~h}$ apresentaram valores de produção de EROs maiores do que os valores das amostras elicitadas, com F-I, durante 24 h. Entretanto, calculandose a tangente das curvas, para determinação da velocidade de liberação de EROs, há pouca diferença entre as produções de EROs das amostras elicitadas com F-I em 1 hora ou 24 horas, apesar de os valores de liberação de EROs serem distintos entre as duas curvas.

Nos tempos menores de elicitação podemos verificar, pela Figura 11, diferenças entre as liberações de EROs para F-I e o controle correspondente. Entretanto, para tempos longos de elicitação, 24 horas, podemos dizer que houve pouca diferença na detecção de EROs, quando comparado o F-I com o respectivo controle. 


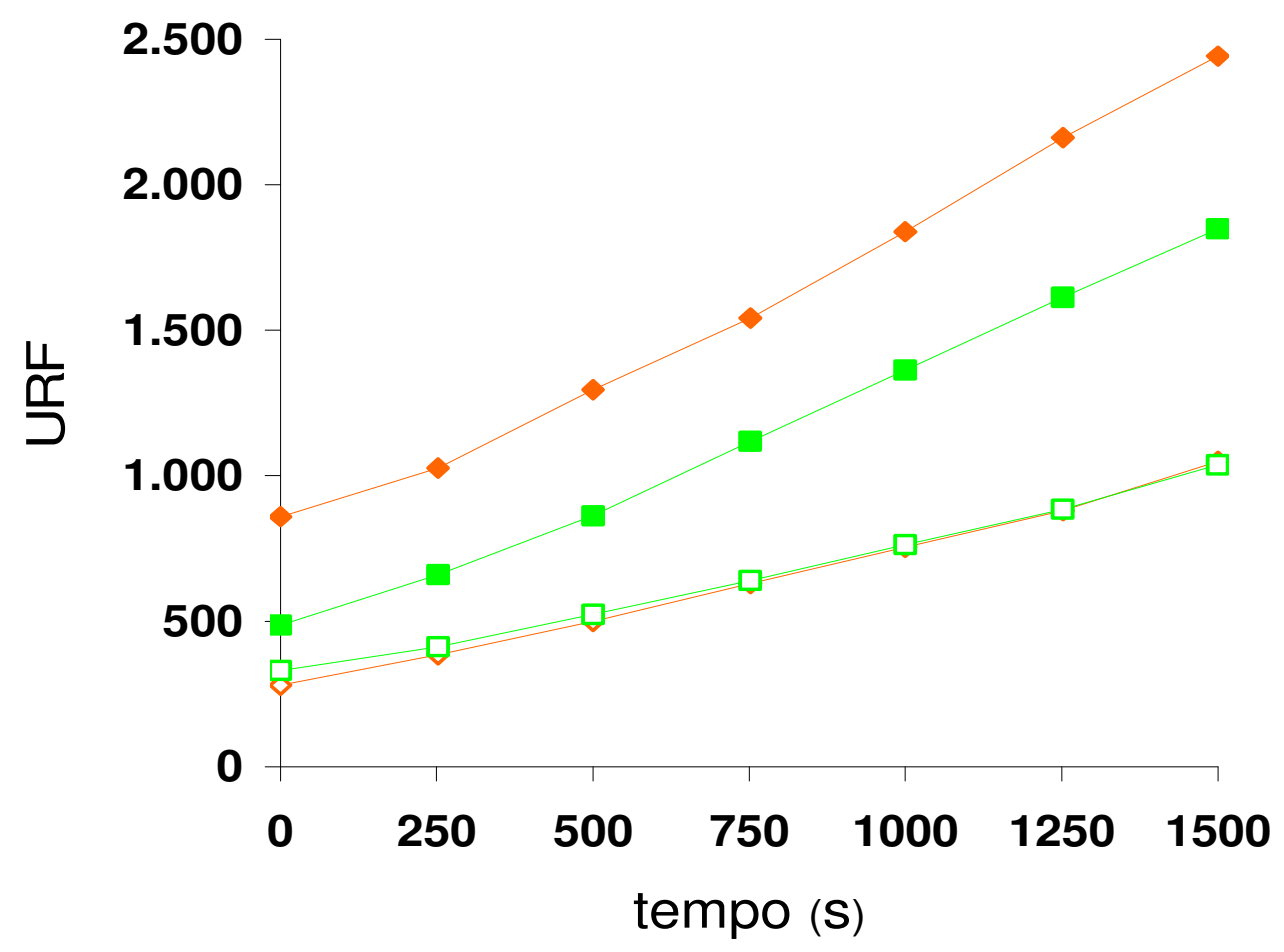

Figura 11. Estudos de elicitações prévias em resposta a liberação de EROs em células de $R$. fruticosus; células de 18 dias, $8 \times 10^{4}$ cél. $/ \mathrm{mL}$ em $2 \mathrm{~mL}$ de amostra; incubação de 20 minutos com $\mathrm{H}_{2}$ DCF-DA $2 \mu \mathrm{mol} / \mathrm{L}$; F-I $[1000 \mathrm{nmol} / \mathrm{L}]$. ( $\left.\diamond\right)$ controle $\left(\mathrm{H}_{2} \mathrm{O}\right)$ com elicitação prévia de 1 hora $(n=2)$; ( $)$ F-I com elicitação prévia de 1 hora $(n=1)$; $(\diamond)$ controle $\left(\mathrm{H}_{2} \mathrm{O}\right)$ com elicitação prévia de 24 horas $(\mathrm{n}=1)$; $(\square) \mathrm{F}$-I com elicitação prévia de 24 horas $(n=2)$. 
Os resultados deste segundo experimento mostraram que os valores de EROs das amostras ficaram na faixa de maior sensibilidade de detecção do aparelho. Portanto, a concentração final do produto fluorescente na amostra e o tempo de incubação com $\mathrm{H}_{2}$ DCF-DA foram adequados para esse modelo experimental.

Do mesmo modo, os resultados do segundo experimento mostraram que os experimentos devem ser realizados sem elicitação prévia das amostras. Há uma tendência à diminuição da liberação de EROs, na cultura de células de amora-preta, a medida que se vai aumentando o período de exposição das células ao elicitor. Isso pode ser explicado pela atuação dos sistemas de defesa antioxidantes das respostas sistêmicas adquirida, (RSA), que protegem as oxidações de açúcares, lipídeos e proteínas das células desencadeadas pelos radicais livres (BREUSEGEM et al., 2001). Uma outra explicação para este efeito de diminuição da liberação de EROs pelo tempo seria a existência de duas fases de produção de EROs nas interações patógeno-hospedeiro: a fase I que é forte e rápida, ocorrendo na primeira hora da interação. Esta fase ocorre tanto em interações compatíveis quanto em incompatíveis e os mecanismos envolvidos devem ser os mesmos. E a fase II que é fraca e lenta, ocorrendo em torno de quatro horas depois da interação. A ocorrência desta fase é característica das interações incompatíveis. São as interações incompatíveis que induzem as plantas a ativarem mecanismos de defesa, como a RH (BAKER; ORLANDI, 1995; DANGL; DIETRICH; THOMAS, 2000; KEPPLER; BAKER, 1989)

Sendo assim, para estudarmos a respostas de defesa adquirida relacionada aos primeiros instantes de exposição da célula ao agente agressor é 
interessante trabalhar com tempos curtos de elicitação (BUCHANAN; GRUISSEM; JONES, 2000).

Os experimentos anteriores foram realizados com uma única molécula elicitora, o F-I. Além disso, os resultados foram obtidos com a concentração de $1000 \mathrm{nmol} / \mathrm{L}$ do elicitor. Deste modo, o próximo experimento foi realizado para verificar as respostas de produção de EROs pelos três elicitores: F-I, AS e MeJA, além de verificar se os efeitos dos elicitores sobre a produção de EROs são dosedependente.

O terceiro, e último, experimento para a padronização dos experimentos de detecção de EROs foi realizado para verificar se concentrações menores do que $1000 \mathrm{nmol} / \mathrm{L}$ de F-I, AS e MeJA conduziriam a mudanças na produção de EROs e, caso existissem, se essas mudanças seriam dependentes da concentração.

Para a elicitação com AS nas diferentes concentrações verificou-se, através da curva de velocidade de produção de EROs, que os valores ficaram próximas ao controle (Figura 12 A). O polissacarídeo F-I apresentou comportamento semelhante ao AS (Figura 12 B). Na Figura 12 C verificamos o comportamento elicitor do metil jasmonato, o qual pareceu ser ativador da produção de EROs em todas as concentrações analisadas, quando comparadas ao controle.

Também podemos verificar que, semelhante ao AS e F-I, as quatro concentrações de MeJA apresentaram produções de EROs próximas entre si. 

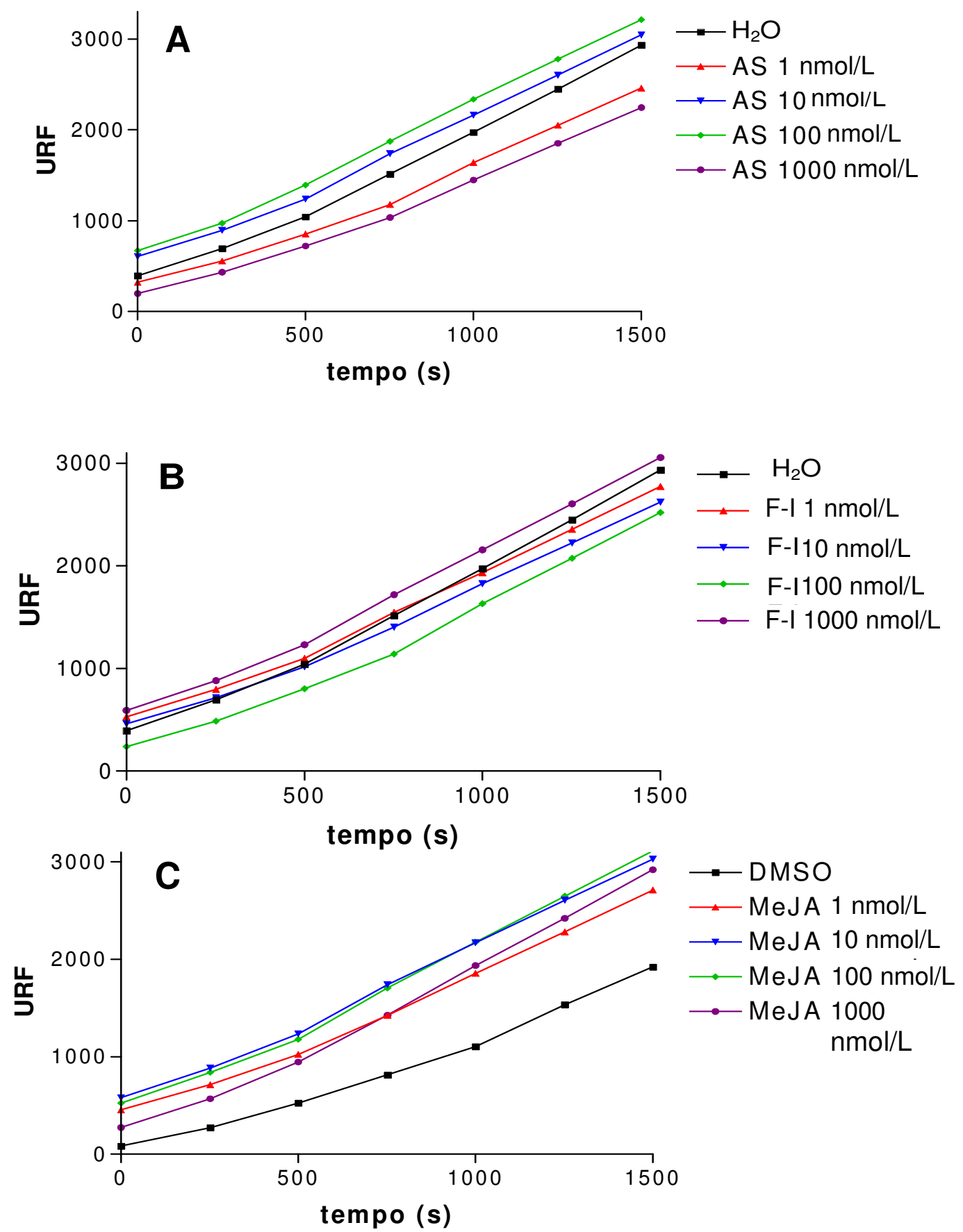

Figura 12. Produção de EROs em diferentes concentrações de F-I, AS e MeJA em células de $R$. fruticosus de 18 dias. Elicitores: A) AS; B) F-I e C) MeJA; as curvas apresentadas foram resultados de 2 experimentos isolados $(n=2)$. 
Nossos estudos mostraram que a detecção de EROs parece não ser dependente da concentração dos elicitores para AS, F-I e MeJA no modelo experimental estudado, para concentração menores do que $1000 \mathrm{nmol} / \mathrm{L}$, pois os resultados de liberação de EROs nos experimentos ficaram muito próximos entre si. O que se distingue dos resultados com fragmentos de poli-GalUA (PGA), onde há uma relação dose-dependente, nos valores de fluorescência relativos à liberação de peróxido de hidrogênio em concentrações acima de 7,5 nmol/L (SHAW; LONG, 2003).

Os resultados obtidos nos levaram a adotar a concentração de $1000 \mathrm{nmol} / \mathrm{L}$ para os elictores (AS, F-I e MeJA) nos experimentos realizados a seguir. Foi escolhida esta concentração porque ela se mostrou aparentemente ativadora da produção de EROs para o polissacarídeo ácido (F-I) (Figura 12 B).

Ao término dos experimentos iniciais, um protocolo padronizado foi obtido para os ensaios de elicitação para a detecção de EROs. Este protocolo foi utilizado como modelo nos ensaios para a determinação de $\mathrm{H}_{2} \mathrm{O}_{2}$ (Figura 13 A e B). 
A

\begin{tabular}{|c|c|c|c|}
\hline $2 \mathrm{~mL}$ de suspensão & & incubação & $\begin{array}{c}\text { (adição dos elicitores) } \\
\text { (tempo de elicitação: } 0 \text { a } 60 \text { min) }\end{array}$ \\
\hline $\begin{array}{l}\text { ( } 8 \times 10^{4} \text { cél./mL) } \\
\text { Rubus fruticosus }\end{array}$ & $\begin{array}{r}\mathrm{H}_{2} \mathrm{DCF}-\mathrm{DA} \\
+(2 \mu \mathrm{mol} / \mathrm{L})\end{array}$ & 20 minutos & $\begin{array}{c}\lambda \text { ex }=503 \mathrm{~nm} \\
\lambda \text { em }=529 \mathrm{~nm} \\
\text { fendas }=5 / 10 \mathrm{~nm} \\
\text { voltagem }=700 \mathrm{~V}\end{array}$ \\
\hline
\end{tabular}

B

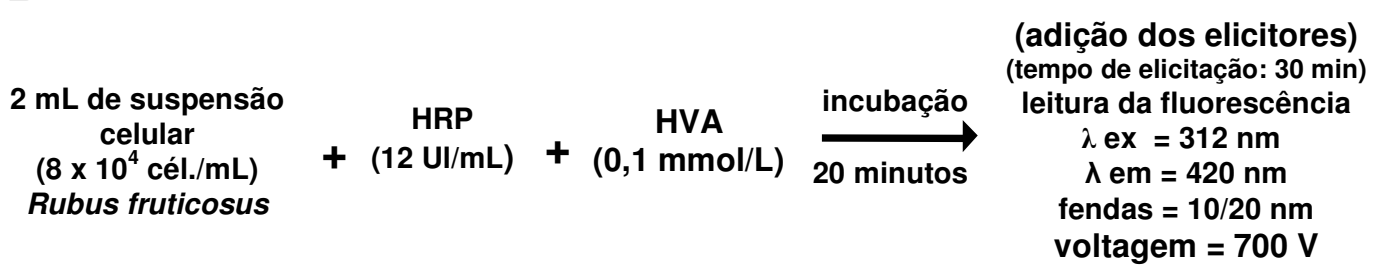

Figura 13. Fluxograma do protocolo experimental para os ensaios de elicitação com F-I, AS, MeJA, e misturas de elicitores, para a determinação da produção de EROs (A) e para a determinação da produção de $\mathrm{H}_{2} \mathrm{O}_{2}(\mathrm{~B})$, em células de 18 dias de $R$. fruticosus.

\subsection{Efeito de F-I, AS e MeJA sobre a produção de EROs em diferentes tempos de elicitação}

Estes experimentos foram realizados para analisar mudanças na liberação de EROs em tempos curtos de elicitação com os diferentes elicitores.

As respostas com AS, F-I e MeJA apresentadas foram resultados de 6 experimentos isolados. Na elicitação com AS e F-I obtivemos uma produção de EROs 30 e $15 \%$ superior ao controle, respectivamente, em 15 minutos de elicitação. O MeJA, por sua vez, foi o menos efetivo, pois apresentou uma produção de $5 \%$ maior que o seu controle em tempos superiores a 30 minutos (Figura $14 \mathrm{~A}$ e B). 
Trabalhos já demonstraram a participação do $A S$ na indução da $R H$ atuando em vias envolvidas na modulação da produção e liberação de EROs (ALLAN; FLUHR, 1997). Nossos resultados mostraram que o AS é o elicitor mais efetivo, com uma produção cerca de $30 \%$ maior que o seu controle para o tempo de 15 minutos, porém esta diferença não apresentou significância estatística. Do mesmo modo, os efeitos indutores do F-I e do MeJA observados não mostraram ser, estatisticamente, diferentes dos seus controles (Figura 15 A, B, C e D). 

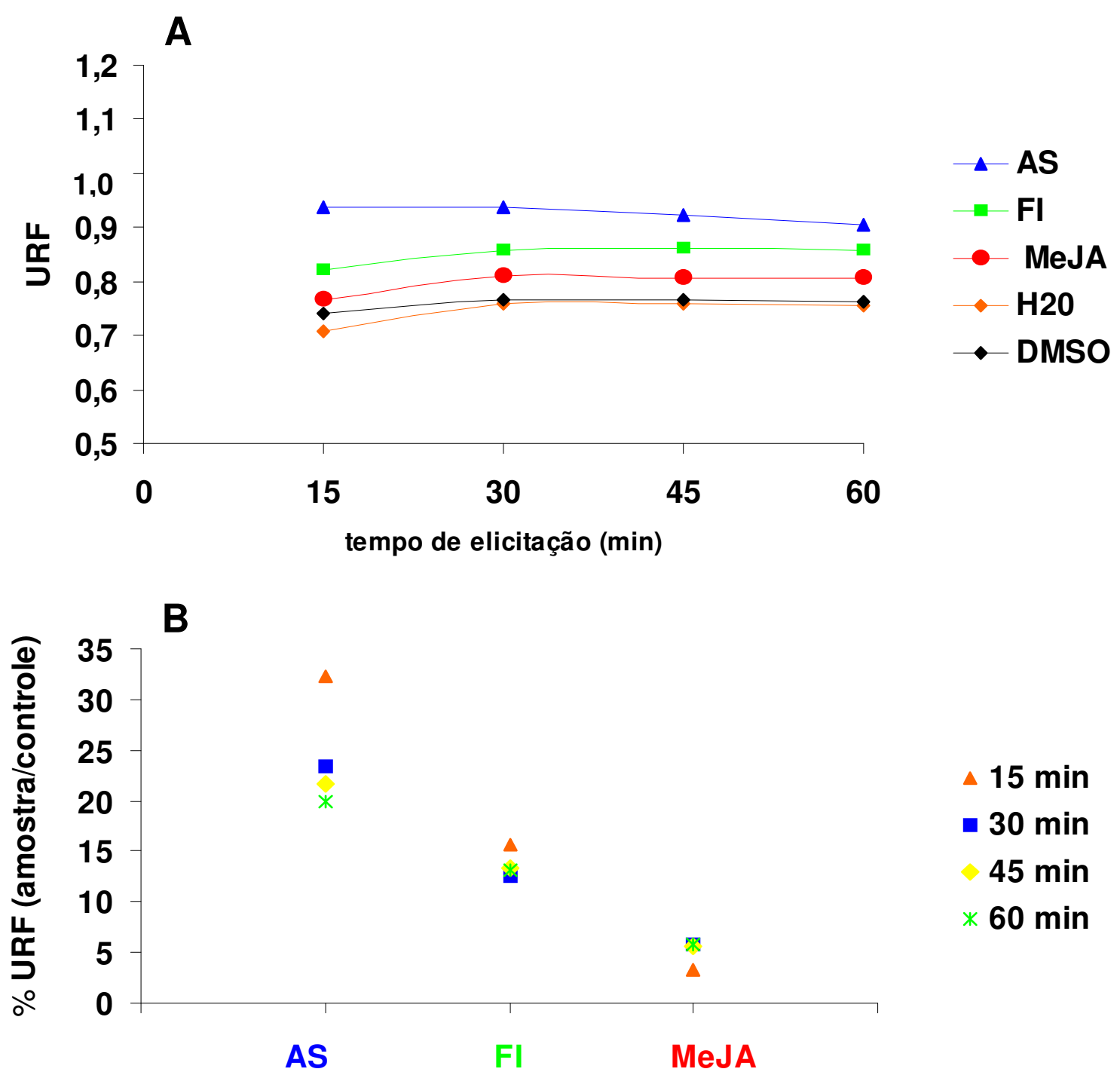

Figura 14. Resposta de liberação de EROs de cultura de células de Rubus fruticosus em função do tempo de elicitação com os elicitores AS, F-I e MeJA (A); Porcentagem (\%) de fluorescência em relaçã ao controle em resposta a liberação de EROs de cultura de células de $R$. fruticosus de 18 dias, com os elicitores AS, F-I e MeJA, em função do tempo de elicitação (B); F-I, AS e MeJA [1000 nmol/L]; as respostas apresentadas foram resultados de 6 experimentos isolados $(n=6)$. 



Figura 15. Resposta de liberação de EROs de cultura de células $\left(8 \times 10^{4}\right.$ cél. $\left./ \mathrm{mL}\right)$ de R. fruticosus de 18 dias com: (A) 15 minutos, (B) 30 minutos, (C) 45 minutos e (D) 60 minutos de elicitação, em elicitações com F-I, AS e MeJA. Incubação de 20 minutos com $\mathrm{H}_{2}$ DCF-DA $2 \mu \mathrm{mol} / \mathrm{L}$; F-I, AS e MeJA [1000 nmol/L]; ( $\left.\mathrm{n}=6\right)$. Os resultados foram submetidos a um teste não-paramétrico do tipo análise da variância de uma via, seguido pelo pós-teste de Tukey. 
Os resultados evidenciaram que os elicitores AS, F-I e MeJA não possuem efeitos sobre a produção de EROs. O polissacarídeo F-I mostrou em estudos anteriores induzir a atividade de proteínas relacionadas à patogênese (proteínasRP) (DE SOUZA, 2005), o que indicou sua função como elicitor de defesa. Além disso, dados de literatura mostram que o MeJA tem a propriedade de inibir a resposta de hipersensibilidade, inibindo as vias que modulam a liberação de EROs (ANDI et al., 2001), o que pode justificar a ausência de efeito na produção de EROs com esse elicitor, ao contrário do AS e do F-I. Apesar disso, o MeJA e seu ácido, o ácido jasmônico, participam de mecanismos alternativos como a resistência sistêmica induzida $(\mathrm{RSI})$ desenvolvida, principalmente, em resposta à herbivoria (DOARES et al., 1995). Além disso, a produção de EROs durante as interações incompatíveis pode ocorrer por mecanismos divergentes em diferentes espécies vegetais e a contribuição de cada mecanismo para o 'burst' oxidativo poderia variar de acordo com a espécie em questão (HAMMOND-KOSACK; JONES, 1996).

\subsection{Efeito da mistura de elicitores sobre a produção de EROs em diferentes tempos de elicitação}

A partir dos resultados do experimento anterior, utilizando as três moléculas elicitoras (MeJA, AS e F-I) de forma individual, onde a produção de EROs aumentou com AS e F-I, porém sem significância estatística, foi de interesse estudar $o$ efeito concomitante de dois elicitores, na mesma concentração usada nos experimentos com elicitores isolados, sobre a produção de EROs em diferentes tempos de elicitação. 
Considerando os quatro tempos de elicitação de forma individual, o tempo de elicitação de 15 minutos é o que apresentou maior produção de EROs para a mistura F-I + MeJA (20\%) e maior inibição para AS + MeJA (50\%). Enquanto que, para a mistura de F-I+AS, o tempo de elicitação com o maior efeito foi de 30 minutos (5\%). Porém, apesar do aumento da produção de EROs das misturas $\mathrm{F}-\mathrm{I}$ + AS e F-I + MeJA ter sido evidenciado pela Figura 16 A e B, estes resultados não foram significativos. Os resultados dos outros tempos de elicitação avaliados são muito próximos entre si. 


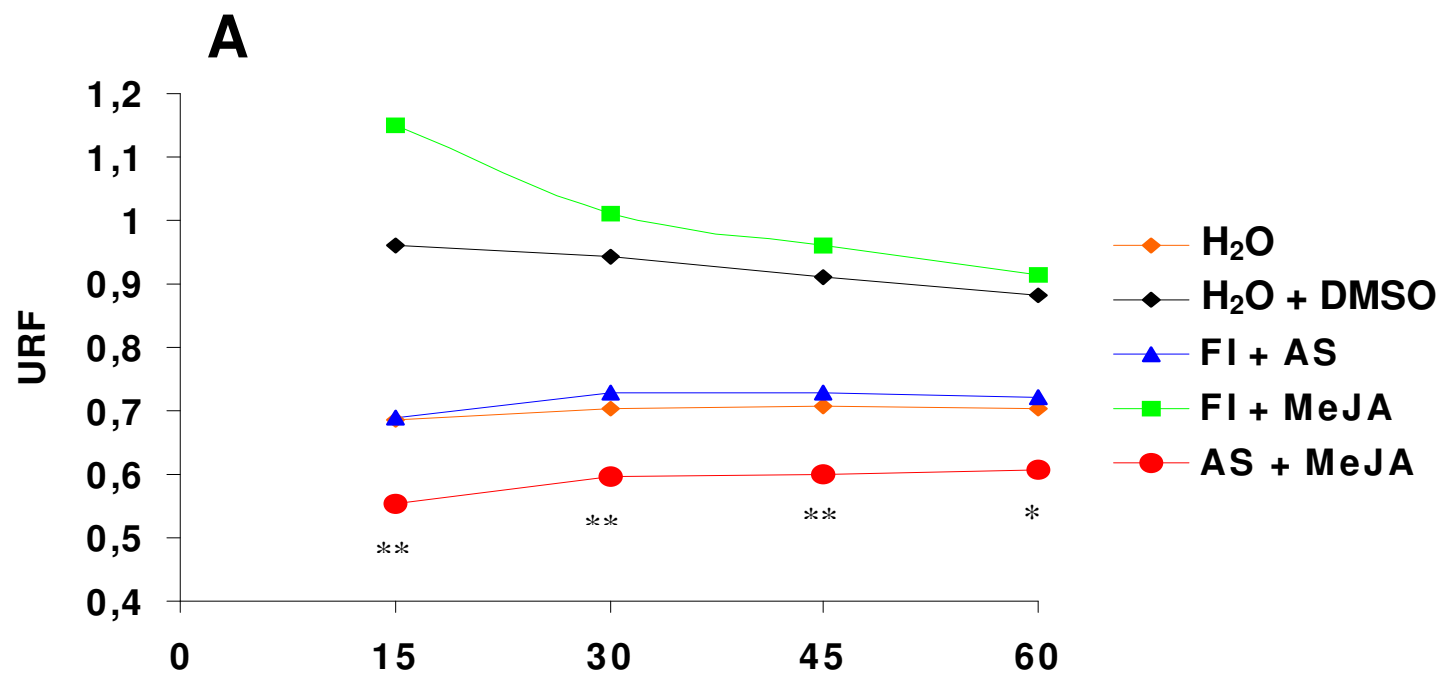

tempo de elicitação ( $m$ in $)$



Figura 16. Resposta de liberação de EROs em cultura de células de Rubus fruticosus em função do tempo de elicitação com F-I + MeJA, AS + MeJA e F-I + AS (A); Porcentagem (\%) de fluorescência em relação ao controle em resposta a liberação de EROs de cultura de células de $R$. fruticosus de 18 dias, com os elicitores F-I + AS; F-I + MeJA e $A S+M e J A$, em função do tempo de elicitação (B); F-I + AS, F-I + MeJA e AS + MeJA [1000 nmol/L]; as respostas apresentadas foram resultados de 6 experimentos isolados $(n=6) ; *(p<0,05)$ nível de significância em relação a $\mathrm{H}_{2} \mathrm{O}+$ DMSO (controle); ** $(\mathbf{p}<\mathbf{0 , 0 1})$ nível de significância em relação a $\mathrm{H}_{2} \mathrm{O}+\mathrm{DMSO}$ (controle). Os resultados foram submetidos a um teste não-paramétrico do tipo análise da variância de uma via, seguido pelo pós-teste de Tukey. 
Analisando os resultados da Figura 17 A, B, C e D, podemos afirmar que os valores de liberação de EROs para a mistura de elicitor F-I + AS, em todos os quatro tempos de elicitação medidos, estão próximos aos valores correspondentes das curvas para os controles. Enquanto que, as diferenças entre amostra e controle para a mistura F-I + MeJA são maiores do que as da mistura F-I + AS, sendo ativadora para o tempo de 15 minutos e inibidora para os outros três tempos. Entretanto, estas diferenças em relação ao controle, nos quatro tempos, para F-I + MeJA não foram relevantes o suficiente para evidenciar um efeito desta mistura sobre a liberação de EROs.

Por outro lado, os valores de detecção de EROs para a mistura AS + MeJA, para todos os quatro tempos calculados, demonstraram serem bastante inibitórias em relação aos respectivos valores do grupo controle, apresentando significância estatística em todos os quatro tempos estudados. 



B

60 minutos
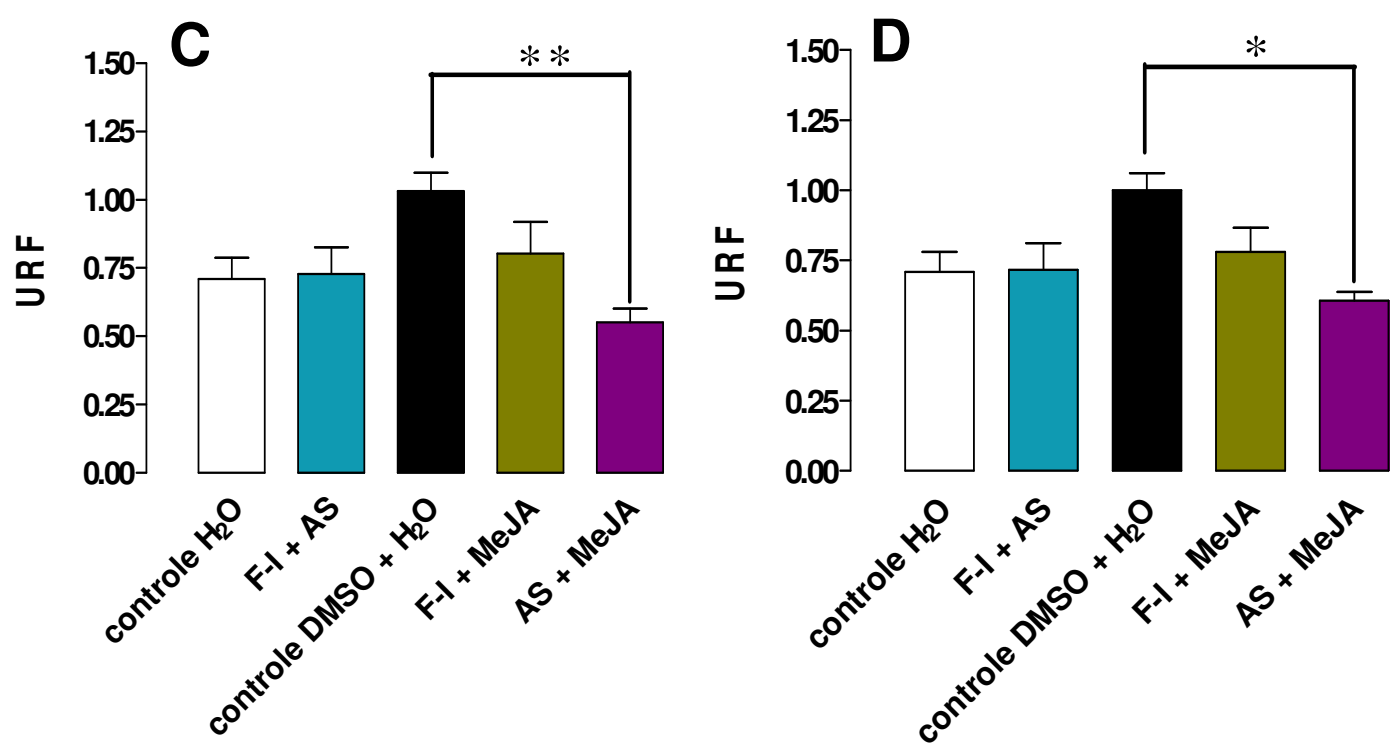

Figura 17. Resposta de liberação de EROs de cultura de células $\left(8 \times 10^{4}\right.$ cél. $\left./ \mathrm{mL}\right)$ de R. fruticosus de 18 dias com: (A) 15, (B) 30, (C) 45 e (D) 60 minutos de elicitação, em elicitações com F-I + AS, F-I + MeJA e AS + MeJA. Incubação de 20 minutos com $\mathrm{H}_{2}$ DCF-DA $2 \mu \mathrm{mol} / \mathrm{L} ; \mathrm{F}-\mathrm{I}+\mathrm{AS}, \mathrm{F}-\mathrm{I}+\operatorname{MeJA}$ e AS + MeJA [1000 nmol/L]; (n=6); * $(\mathbf{p}<\mathbf{0 , 0 5})$ nível de significância em relação a $\mathrm{H}_{2} \mathrm{O}+\mathrm{DMSO}$ (controle); ** $(\mathbf{p}<\mathbf{0 , 0 1})$ nível de significância em relação a $\mathrm{H}_{2} \mathrm{O}+$ DMSO (controle). Os resultados foram submetidos a um teste não-paramétrico do tipo análise da variância de uma via, seguido pelo pós-teste de Tukey. 
Os resultados evidenciaram que os elicitores AS e MeJA, quando administrados em conjunto, e na mesma concentração, possuem efeito inibidor sobre a produção de EROs. Apesar do AS e do MeJA estarem envolvidos em diferentes vias de sinalização, existe uma relação antagonista entre estas duas moléculas, principalmente no que refere-se à via ativada na herbivoria (DOARES et al., 1995). O efeito inibitório do AS em genes que codificam para inibidores de proteinase é revertido pelo pré-tratamento das plantas com MeJA e etileno (ODONELL et al., 1996). Este fato sugere que o AS inibe a síntese destas moléculas, responsáveis pela ativação dos mecanismos de defesa requeridos durante a herbivoria.

Entretanto, outros estudos, em folhas de pimenta, falam que o MeJA induz a expressão de genes relacionados a resposta de hipersensibilidade. Além disso, o envolvimento do MeJA na indução da $\mathrm{RH}$ estaria relacionado a eventos celulares que não envolvem a participação de outras moléculas elicitoras, inclusive do etileno e do AS (KONG et al., 2002). Sendo assim, a inibição da produção de EROs pode ser devido ao antagonismo entre os eventos sinalizadores do AS e os do MeJA.

\subsection{Efeitos dos elicitores sobre a produção de $\mathrm{H}_{2} \mathrm{O}_{2}$ em relação} aos seus controles

Todos estes resultados, referentes à detecção de EROs em amostras elicitadas por elicitores e por misturas de elicitores, mostraram que estas moléculas podem atuar modulando a produção de EROs, como foi visto com a inibição causada pela mistura AS + MeJA neste modelo experimental. Neste sentido, seria interessante determinar quais espécies reativas de oxigênio estariam envolvidas nestas respostas. 
O peróxido de hidrogênio é uma EROs conhecida por estar envolvida nas respostas de defesa das plantas (MELLERSH et al., 2002). Portanto, um estudo que possa apontar a presença desta molécula em ensaios de elicitação seria interessante. Neste sentido foram realizados os experimentos a seguir.

As respostas de detecção de $\mathrm{H}_{2} \mathrm{O}_{2}$ foram resultados de 4 experimentos isolados. Os experimentos de detecção de $\mathrm{H}_{2} \mathrm{O}_{2}$ foram estudados utilizando como molécula fluorescente o ácido homovanílico (HVA) que se torna fluorescente ao reagir com o substrato $\mathrm{H}_{2} \mathrm{O}_{2}$ ligado a enzima peroxidase HRP (peroxidase de rabanete), a qual também é adicionada ao meio de reação (BARJA, 2002).

Os experimentos de detecção de $\mathrm{H}_{2} \mathrm{O}_{2}$ foram desenvolvidos encubando o HVA por 20 minutos antes da leitura da liberação de $\mathrm{H}_{2} \mathrm{O}_{2}$, pois em experimentos preliminares verificou-se também a necessidade de incubação, sem a qual não havia valores de fluorescência detectáveis. A incubação foi realizada seguindo o mesmo padrão dos experimentos de EROs.

Escolheu-se o tempo de elicitação de 30 minutos para os experimentos de detecção de $\mathrm{H}_{2} \mathrm{O}_{2}$ devido aos resultados dos experimentos de EROs. Nos experimentos de detecção de EROs os tempos de elicitação que obtiveram os valores mais representativos em relação aos controles foram os tempos de 15 e 30 minutos, apesar de todos os quatro tempos terem mostrado valores muito próximos entre si.

A elicitação com AS e F-I, Figura 18 A e B mostraram um aumento na liberação $\mathrm{H}_{2} \mathrm{O}_{2}$ em relação ao controle de 50 e $20 \%$, respectivamente. O MeJA praticamente não teve efeito sobre a produção de $\mathrm{H}_{2} \mathrm{O}_{2}$, cerca de $5 \%$ em relação 
ao seu controle. Apesar disso, apenas a produção de $\mathrm{H}_{2} \mathrm{O}_{2}$ das amostras elicitadas com AS apresentaram significância estatística (Figura 19).


Figura 18. Razão entre as curvas de fluorescência do HVA das amostras elicitadas com F-I, AS e MeJA pelo controle, em resposta a liberação de $\mathrm{H}_{2} \mathrm{O}_{2}$ de cultura de células de Rubus fruticosus, em 30 minutos de elicitação (A); Porcentagem (\%) de fluorescência das amostras elicitadas em relação ao controle em resposta a liberação de $\mathrm{H}_{2} \mathrm{O}_{2}$ de cultura de células de $R$. fruticosus de 18 dias, com os elicitores AS, F-I e MeJA, em 30 minutos de elicitação (B); F-I, AS e MeJA [1000 nmol/L]; as respostas apresentadas foram resultados de 4 experimentos isolados $(n=4)$. 


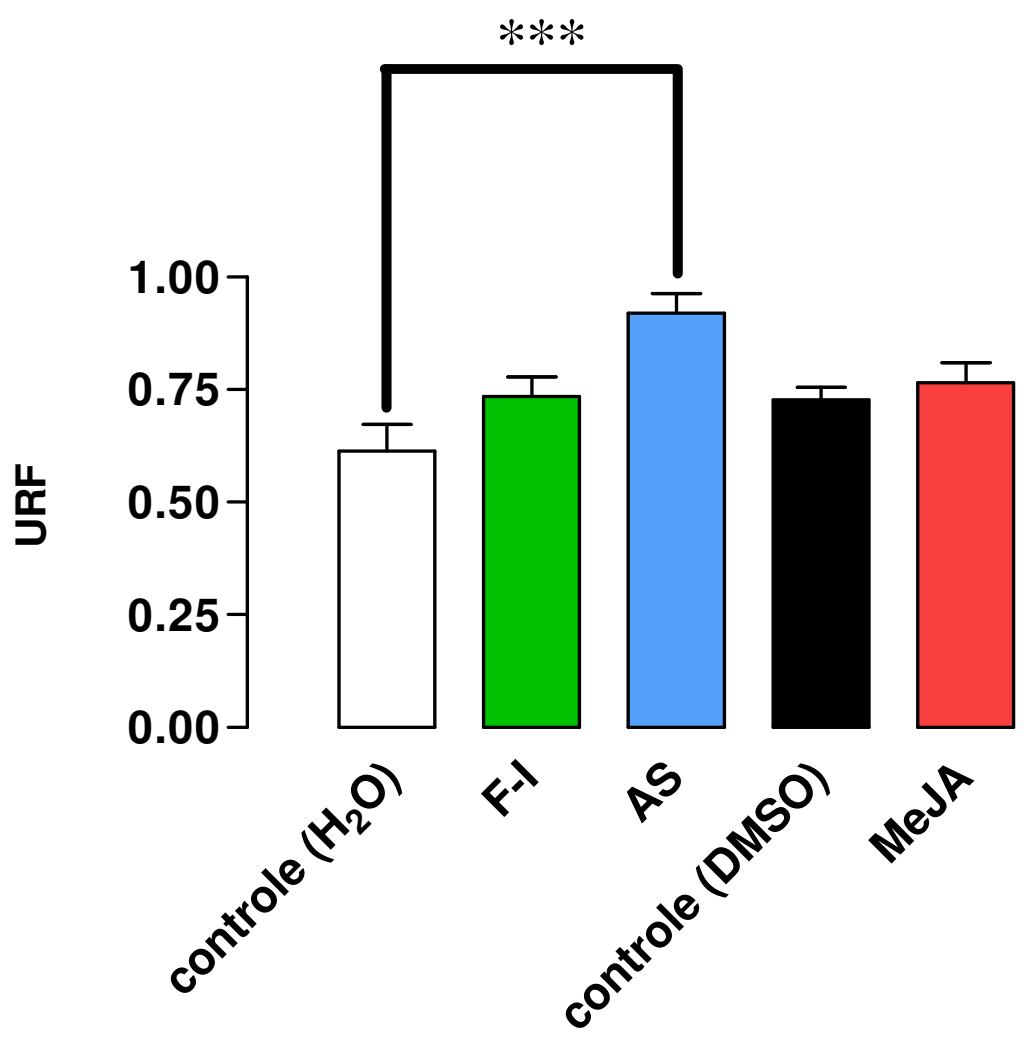

Figura 19. Fluorescência do HVA em resposta a liberação de $\mathrm{H}_{2} \mathrm{O}_{2}$ de cultura de $R$. fruticosus com 30 minutos de elicitação, em elicitações com F-I, AS e MeJA. Células de 18 dias, $8 \times 10^{4}$ cél. $/ \mathrm{mL}$ em $2 \mathrm{~mL}$ de amostra. Incubação de 20 minutos com HRP $12 \mathrm{UI} / \mathrm{mL}$ e HVA 0,1 mmol/L, seguida da adição do elicitor ou controle; F-I, AS e MeJA [1000 nmol/L]; $(\mathrm{n}=4)$; fluorímetro Hitachi F-4500 com (ex./em):(312/420 nm), fendas (10/20 nm) e voltagem (700 V); HVA = ácido homovanílico; HRP = peroxidase de rabanete; $* * *(p<0,001)=$ nível de significância em relação a $\mathrm{H}_{2} \mathrm{O}$ (controle). Os resultados foram submetidos a um teste não-paramétrico do tipo análise da variância de uma via, seguido pelo pós-teste de Tukey. 
Nossos estudos mostraram que o AS exógeno aumenta os níveis de $\mathrm{H}_{2} \mathrm{O}_{2}$ em células em suspensão de amora-preta. Ao passo que o $\mathrm{H}_{2} \mathrm{O}_{2}$ é uma EROs, é de se esperar um aumento semelhante na produção de EROs em células elicitadas com AS. Porém, considerando os nossos resultados não foi verificada uma produção aumentada de EROs em amostras elicitadas com AS, na mesma proporção que observada para $\mathrm{O} \quad \mathrm{H}_{2} \mathrm{O}_{2}$. Esses resultados podem ser conseqüências do tipo de molécula utilizada para conferir fluorescência às amostras.

A molécula que conferiu fluorescência para as amostras nas quais foi medida a produção de EROs foi o $\mathrm{H}_{2}$ DCF-DA. Esta molécula reage com todas as EROs produzidas durante a elicitação. Por outro lado, a molécula fluorescente HVA, utilizada na análise da produção de $\mathrm{H}_{2} \mathrm{O}_{2}$ não é especifica, mas possuiu uma afinidade maior ao complexo $\mathrm{HRP}-\mathrm{H}_{2} \mathrm{O}_{2}$ do que para as outras EROs (BARJA, 2002) e, sendo assim, este método é mais sensível para detectar diferenças na produção de $\mathrm{H}_{2} \mathrm{O}_{2}$.

A influência do AS sobre o acúmulo do $\mathrm{H}_{2} \mathrm{O}_{2}$ é objeto de estudos a respeito de mecanismos de resistência a doenças. A adição de $50 \mu \mathrm{mol} / \mathrm{L}$ de AS induz à $\mathrm{RH}$ e ao acúmulo de $\mathrm{H}_{2} \mathrm{O}_{2}$ em células de soja contra $P$. syringae pv glycinea. A indução da $\mathrm{RH}$ e do acúmulo de $\mathrm{H}_{2} \mathrm{O}_{2}$, em cultura de células de soja inoculadas com a bactéria $P$. syringae pv glycinea, é bloqueada pela adição do ácido $\alpha$-aminooxi- $\beta$-fenilpropiônico que inibe a biossíntese dos fenilpropanóides, os quais fazem parte de uma via para a biossíntese do ácido salicílico. Estas respostas podem ser resgatadas pela adição de AS exógeno (SHIRAZU et al., 1997). 
Uma característica distintiva das lesões de hipersensibilidade é o limite curto que é estabelecido entre tecido vivo e tecido morto, subseqüentemente ao primeiro aparecimento dos sintomas de morte. Embora a ativação de resistência mediada por genes $\mathrm{R}$ seja autônoma para cada célula, os sinais extracelulares ou difusíveis gerados nas células atacadas podem desencadear respostas nas células não infectadas da vizinhança. Sendo assim, uma molécula chave na sinalização da $\mathrm{RH}$ pode ser a distribuição não homogênea de AS dentro das lesões. É assumido que sinais difusíveis gerados pela distribuição não-homogênea do AS em células infectadas ativam respostas nas células de uma maneira não-autônoma. Um dos sinais difusíveis do AS pode ser $0 \mathrm{H}_{2} \mathrm{O}_{2}, 0$ qual difundi-se através das membranas e reage a baixas concentrações nas lesões marginais. $\mathrm{O} \mathrm{H}_{2} \mathrm{O}_{2}$ pode ter um papel duplo na $\mathrm{RH}$, ativando a morte celular em altas concentrações e induzindo a expressão de genes antioxidantes em baixas concentrações (ALVARES, 2000).

Embora moderadamente reativa por ela própria, muito do prejuízo celular causado pelo $\mathrm{H}_{2} \mathrm{O}_{2}$ resulta da conversão dessa molécula para espécies ainda mais reativas. Por exemplo, podemos citar a conversão do $\mathrm{H}_{2} \mathrm{O}_{2}$, na presença de ferro, para $\mathrm{OH}$, extremamente tóxico (BREUSEGEM et al., 2001). Esse radical pode reagir com proteínas e assim reduzir a atividade de enzimas, ou reagir com lipídios e aumentar a permeabilidade de membranas e ainda reagir com o DNA causando mutações (MOLLER, 2001).

\subsection{Efeitos das misturas de elicitores sobre a produção de $\mathrm{H}_{2} \mathrm{O}_{2}$}

Considerando o fato de que o grupo elicitado por AS induziu a produção de $\mathrm{H}_{2} \mathrm{O}_{2}$, e também devido aos experimentos utilizando misturas de elicitores na 
mesma concentração terem sido estudados nas análises de produção de EROs, foram realizados os estudos sobre a liberação de $\mathrm{H}_{2} \mathrm{O}_{2}$ pelas células elicitadas de R. fruticosus com as misturas de elicitores em ensaio de elicitação de 30 minutos.

As culturas de células de amora-preta elicitadas com F-I + AS foram indutoras da liberação de $\mathrm{H}_{2} \mathrm{O}_{2}$, em comparação aos grupos controle, com um valor de indução aproximadamente $28 \%$ maior (Figura 20 A e B). Entretanto, as misturas de $\mathrm{F}-\mathrm{I}$ + MeJA e AS + MeJA foram inibidoras da produção de $\mathrm{H}_{2} \mathrm{O}_{2}$ em relação ao controle, sendo a mistura AS + MeJA a mais inibitória ( 28\%). O poder inibitório sobre a produção de $\mathrm{H}_{2} \mathrm{O}_{2}$ da mistura $\mathrm{AS}+\mathrm{MeJA}$ foi o único que mostrou significância estatística (Figura 21).

Analisando os dados de produção de $\mathrm{H}_{2} \mathrm{O}_{2}$ pelas Figuras $18 \mathrm{~B}$ e $20 \mathrm{~B}$, entre as amostras elicitadas apenas com um elicitor, com os dados dos grupos elicitados com as misturas de elicitores, nossos resultados mostraram que a mistura $\mathrm{F}-\mathrm{I}$ + AS obteve uma liberação de $\mathrm{H}_{2} \mathrm{O}_{2}$ maior do que $\mathrm{F}-\mathrm{I}$ e menor quando comparada ao AS. O AS, na mistura AS + F-I, teve o seu efeito inibido (de 50 para $28 \%$ ), ao passo que o $\mathrm{F}-\mathrm{I}$ teve um aumento no efeito indutor, de 20 para 28\%. Na mistura F-I + MeJA ocorreu uma mudança no comportamento dos elicitores, passando de indutores, quando sozinhos, para levemente inibidores da produção de $\mathrm{H}_{2} \mathrm{O}_{2}(10 \%)$. A mesma mudança de efeito indutor para inibitório foi verificado para a mistura $A S$ + MeJA sendo que esta inibição ( 28\%) em relação ao controle, tem significância estatística. 



Figura 20. Razão entre as curvas de fluorescência do HVA das amostras elicitadas com $\mathrm{F}-\mathrm{I}+\mathrm{AS}, \mathrm{F}-\mathrm{I}+\mathrm{MeJA}$ e AS + MeJA pelo controle em resposta a liberação de $\mathrm{H}_{2} \mathrm{O}_{2}$, de cultura de células de Rubus fruticosus, em 30 minutos de elicitação (A); Porcentagem (\%) de fluorescência em relação ao controle em resposta a liberação de $\mathrm{H}_{2} \mathrm{O}_{2}$ de cultura de células de $R$. fruticosus de 18 dias, com os elicitores F-I + AS, F-I + MeJA e AS + MeJA, em 30 minutos de elicitação (B); F-I + AS, F-I + MeJA, AS + MeJA [1000 nmol/L]; as respostas apresentadas foram resultados de 4 experimentos isolados $(n=4)$. 




Figura 21. Fluorescência do HVA em resposta a liberação de $\mathrm{H}_{2} \mathrm{O}_{2}$ de cultura de R. fruticosus com 30 minutos de elicitação, em elicitações com F-I + AS, F-I + MeJA, AS + MeJA. Células de 18 dias, $8 \times 10^{4}$ cél./mL em $2 \mathrm{~mL}$ de amostra. Incubação de 20 minutos com HRP $12 \mathrm{UI} / \mathrm{mL}$ e HVA $0,1 \mathrm{mmol} / \mathrm{L}$, seguida da adição do elicitor ou controle; F-I + AS, F-I + MeJA e AS + MeJA [1000 nmol/L]; $(n=4) ; H V A=$ ácido homovanílico; HRP = peroxidase de rabanete; $*(p<0,05)=$ nível de significância em relação a $\mathrm{H}_{2} \mathrm{O}+$ DMSO (controle). Os resultados foram submetidos a um teste nãoparamétrico do tipo análise da variância de uma via, seguido pelo pós-teste de Tukey. 
Nossos experimentos evidenciaram que a mistura AS + MeJA inibe a produção de $\mathrm{H}_{2} \mathrm{O}_{2}$, assim como a produção de EROs. Entretanto, o efeito inibitório da produção de EROs foi maior do que a inibição da liberação de $\mathrm{H}_{2} \mathrm{O}_{2}$. Este resultado pode sugerir que o efeito inibitório da mistura AS + MeJA não é devido, predominantemente, a inibição da produção de $\mathrm{H}_{2} \mathrm{O}_{2}$ e sim de outras EROs. Existem alguns trabalhos estabelecendo uma relação entre os efeitos do AS e àqueles dos jasmonatos sobre a presença de $\mathrm{H}_{2} \mathrm{O}_{2}$ associada aos mecanismos de resistência em plantas.

Um ecotipo de Arabidopsis foi estudado para verificar a sinalização do AS e AJ atuando na morte celular induzida por ozônio. O tratamento destas plantas com MeJA reduziu o nível de $\mathrm{H}_{2} \mathrm{O}_{2}$ e de $\mathrm{AS}$, além de impedir a morte celular, em células expostas ao ozônio. Estas e outras análises com plantas mutantes demonstraram a relação antagonista entre as vias sinalizadoras de AJ e AS, no controle da morte celular associada a $\mathrm{RH}$ induzida pelo $\mathrm{O}_{3}$ (RAO et al., 2000).

Um experimento que utilizou a infiltração da $\beta$-megaspermina na folhas, para avaliar a ativação da atividade da PLA2 em relação ao acúmulo de jasmonatos e de AS endógeno, em tabaco, mostrou que o acúmulo de jasmonatos não é afetado por concomitante indução de $\mathrm{RH}$ intensificada pelo AS endógeno. Esses dados demonstram que o antagonismo metabólico entre os níveis de $A S$ e $A J$, que tem sido relatado em estudos anteriores, não opera quando os metabolismos de ambos estão ativados na $\mathrm{RH}$ para o tabaco (DHONDT et al., 2002). 


\subsection{Análise dos açúcares liberados na fração $S$ por cromatografia em camada delgada (CCD)}

Para verificar se os efeitos dos elicitores na parede celular, causava alterações na parede celular de $R$. fruticosus, foi realizada, inicialmente, a análise da liberação de açúcares para o meio extracelular por CCD na fração sobrenadante.

As frações $S$ obtidas com o $\mathrm{F}-\mathrm{I}$ e seu controle, nos experimentos de elicitação de 1 e 24 h foram analisadas por CCD para verificar se havia liberação de açúcares para o meio extracelular e a faixa de massa molecular destes oligossacarídeos. Na Figura 22, podemos observar que não há diferença em relação aos tipos de açúcares que compõem a fração $S$ da amostra elicitada com o elicitor F-I e o controle, tanto com 1 hora quanto com 24 horas de elicitação. Além disso, podemos dizer que os açúcares presentes nestas amostras de frações S são de tamanhos que compreendem os mono e os dissacarídeos, ao compará-los com as manchas dos padrões de massa molecular utilizados. 


\section{M \\ D}

\section{$\mathbf{T}$}

$\mathbf{P}$
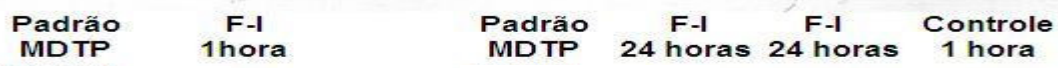

Figura 22. Cromatografia em camada delgada (CCD) para avaliar o perfil de açúcar em uma amostra elicitada com F-I. A fase estacionária foi composta por sílica-gel (Kieselgel $60 \mathrm{~F}_{254}$-MERK). A fase móvel foi composta por butanol:etanol: $\mathrm{H}_{2} \mathrm{O}$ (5:3:2). Como revelador usou-se a mistura $\mathrm{H}_{2} \mathrm{SO}_{4}$ :etanol (9:1). Adicionaram à placa $5 \mu \mathrm{L}$ de amostras sobrenadantes (fração $S$ ) elicitadas por 1 hora e 24 horas com $\mathrm{H}_{2} \mathrm{O}$ (controle) e F-I 1000 nmol/L. Utilizou-se $5 \mu \mathrm{L}$ de Padrão cromatográfico MDTP (mono, di, tetra e pentassacarídeos de glucose) na concentração de $2 \mathrm{mg} / \mathrm{mL}$.

Ao verificar a Figura 23, podemos sugerir que não há diferença entre os açúcares ao relacionar a amostra elicitada com AS e o controle. Além disso, podemos dizer que, tanto na amostra elicitada com AS quanto na amostra controle existem duas manchas cromatográficas. Essas manchas, comparadas às da amostra padrão, provavelmente são mono ou dissacarídeos.

Esses resultados nos demonstraram que acontece uma liberação de açúcares para o meio extracelular em cultura de células de $R$. fruticosus, nas condições experimentais analisadas. 


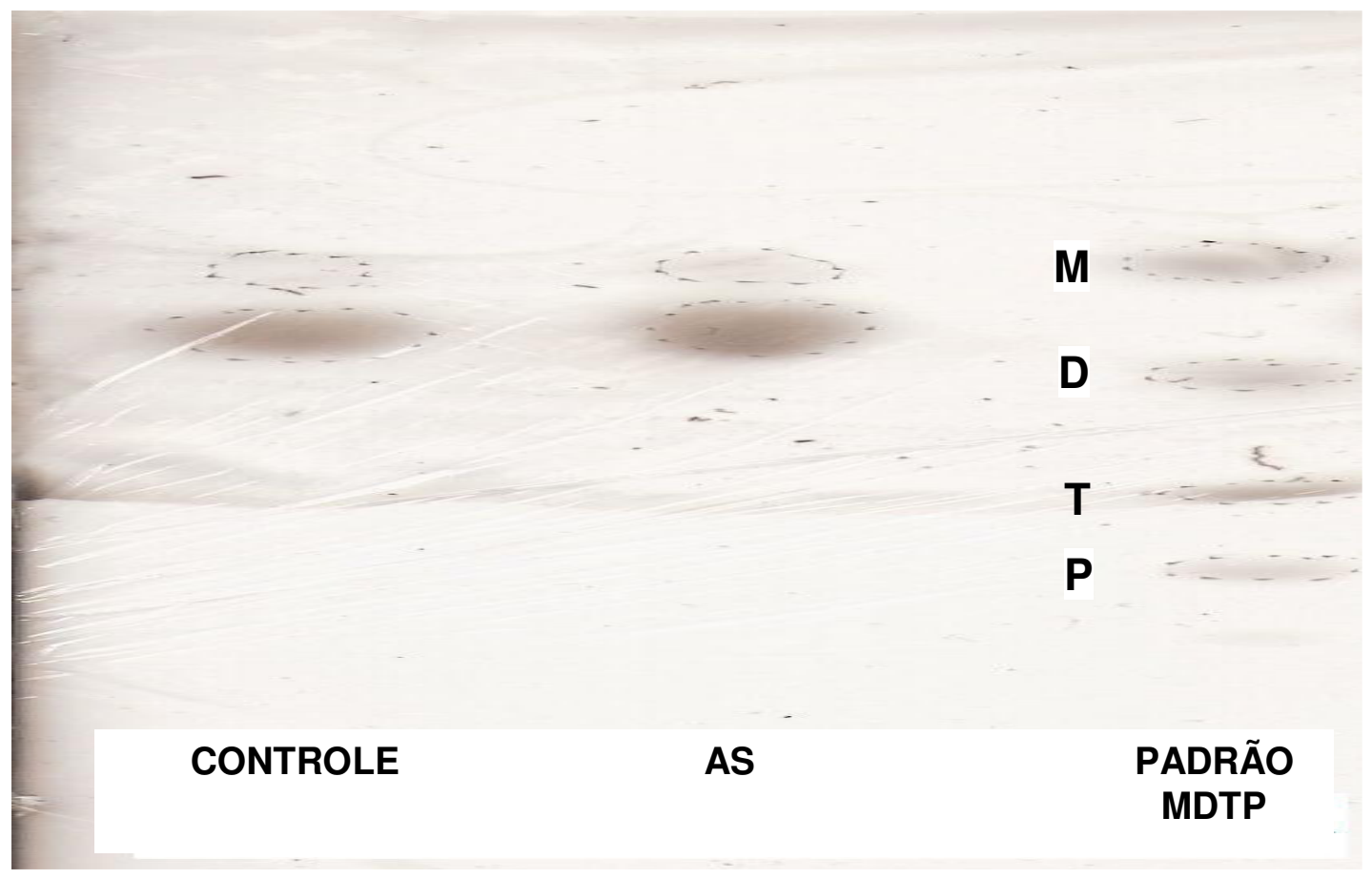

Figura 23. Cromatografia em camada delgada (CCD) para avaliar o perfil de açúcar em uma amostra elicitada com AS. A fase estacionária foi composta por sílica-gel (Kieselgel $60 \mathrm{~F}_{254}-\mathrm{MERK}$ ). A fase móvel foi composta por butanol:etanol: $\mathrm{H}_{2} \mathrm{O}$ (5:3:2). Como revelador usou-se a mistura $\mathrm{H}_{2} \mathrm{SO}_{4}$ :etanol (9:1). Adicionaram à placa $5 \mu \mathrm{L}$ de amostras sobrenadantes (fração $S$ ) elicitadas por 30 minutos com $\mathrm{H}_{2} \mathrm{O}$ (controle) e AS $1000 \mathrm{nmol} / \mathrm{L}$. Utilizou-se $5 \mu \mathrm{L}$ de Padrão cromatográfico MDTP (mono, di, tetra e pentassacarídeos de glucose) na concentração de $2 \mathrm{mg} / \mathrm{mL}$.

\subsection{Análise do teor de açúcar liberado para o meio extracelular em células de $R$. fruticosus elicitadas com AS, F-I, MeJA e suas misturas}

Ainda com o objetivo de avaliar os efeitos dos elicitores sobre a parede celular, foi determinado o teor de açúcar liberado para o meio extracelular para verificar as variações na quantidade de açúcar devido as diferentes elicitações. 
Foram realizados experimentos de elicitação com um tempo de 60 minutos de acordo com o protocolo padronizado de ensaios de elicitação, utilizando os diferentes elicitores na concentração de $1000 \mathrm{nmol} / \mathrm{L}$. Foi determinado o teor de açúcar redutor e não o de açúcar total, a fim de eliminarmos a interferência da sacarose existente no tampão de elicitação. Os resultados apresentados na Figura 24 que mostram os teores de açúcares redutores liberados no meio extracelular (fração S), demonstram que F-I e AS tiveram um aumento nos teores de açúcar redutor de 30 e 10\%, respectivamente. Porém, a amostra induzida com MeJA apresentou uma diminuição dos valores de açúcar redutor de 8\%, em relação ao seu controle. Apesar disto, todas estas alterações não demonstraram efeitos significativos (Figura 25). Entretanto, a porcentagem de açúcar redutor da amostra pelo controle demonstra haver uma modulação na liberação de açúcares redutores de acordo com o indutor utilizado.

As amostras elicitadas com as misturas de elicitores (Figura 26), apresentaram inibição na liberação de açúcares para o meio extracelular, de 8, 30 e 15\% para F-I + AS, F-I + MeJA e AS + MeJA, respectivamente. As diferenças entre os teores de açúcar redutor das amostras elicitadas com as misturas de elicitores em relação aos seus controles não apresentaram significância estatística (Figura 27), entretanto, demonstram haver uma modulação na liberação de açúcares redutores de acordo com o indutor utilizado ao analisar a porcentagem de açúcar redutor da amostra pelo controle. 


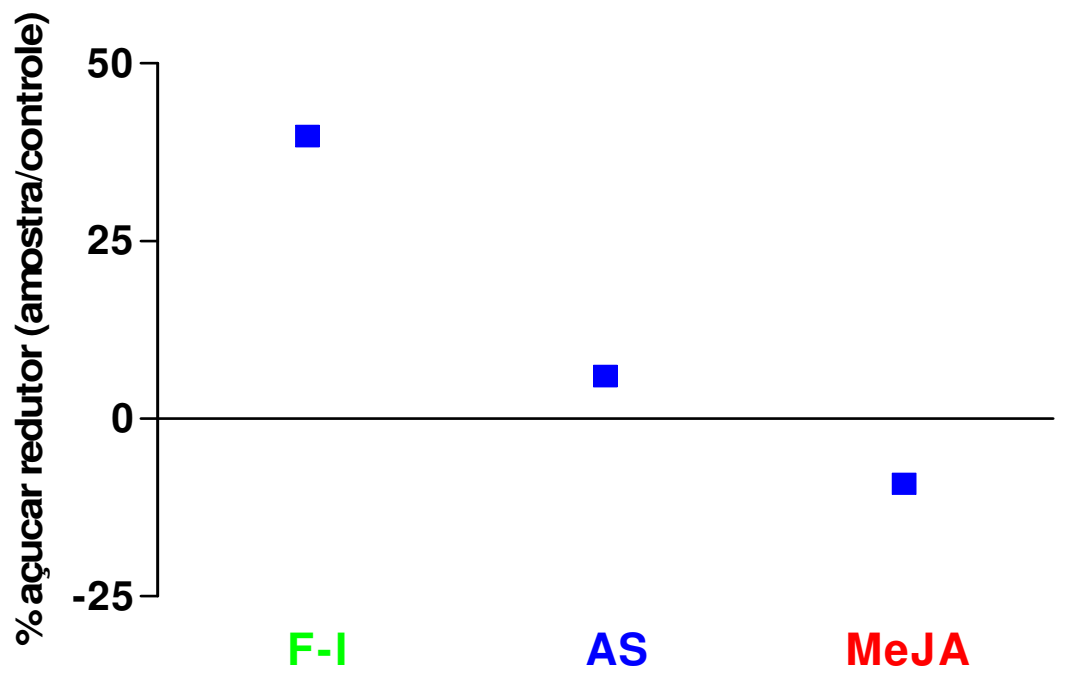

Figura 24. Porcentagem (\%) de açúcar redutor das amostras elicitadas com F-I, AS e MeJA em relação ao controle da fração sobrenadante (fração $S$ ) de ensaios de elicitação com tempo de elicitação de 60 minutos.



Figura 25. Teor de açúcar redutor em cultura de células de $R$. fruticosus com 60 minutos de elicitação; células de 18 dias, $8 \times 10^{4}$ cél. $/ \mathrm{mL}$ em $25 \mathrm{~mL}$ de amostra; F-I, AS e MeJA [1000 nmol/L]; $(n=6)$. Os resultados foram submetidos a um teste não-paramétrico do tipo análise da variância de uma via, seguido pelo pós-teste de Tukey. 


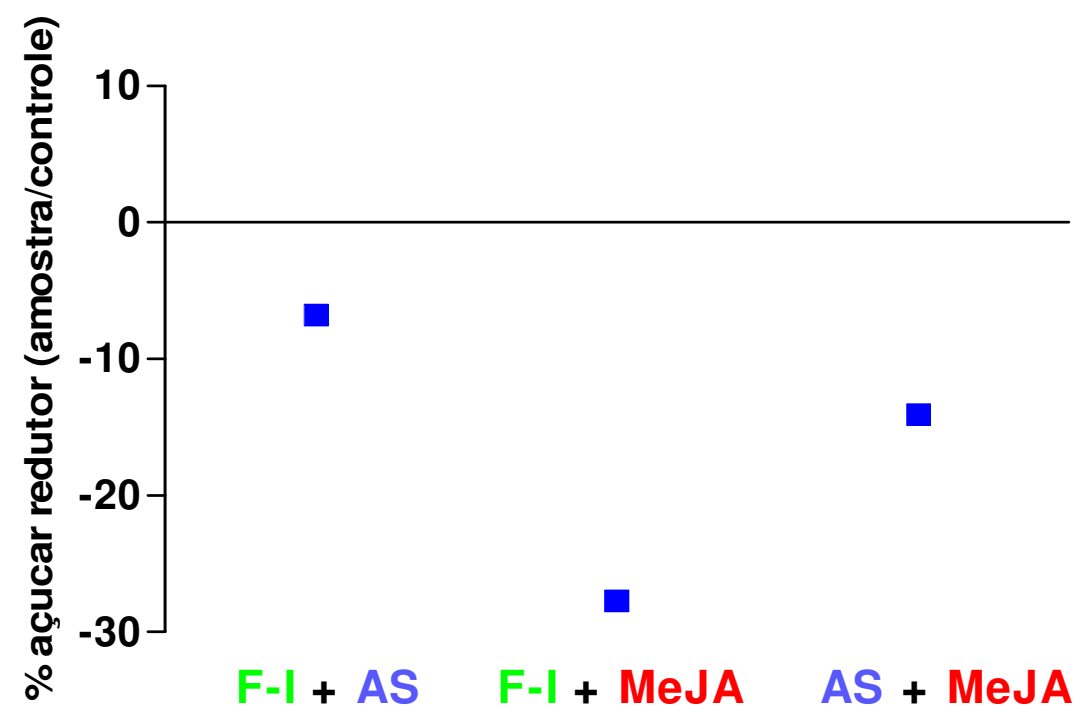

Figura 26. Porcentagem (\%) de açúcar redutor das amostras elicitadas com F-I + AS, F-I + MeJA e AS + MeJA em relação ao controle da fração S; elicitação de 60 minutos.

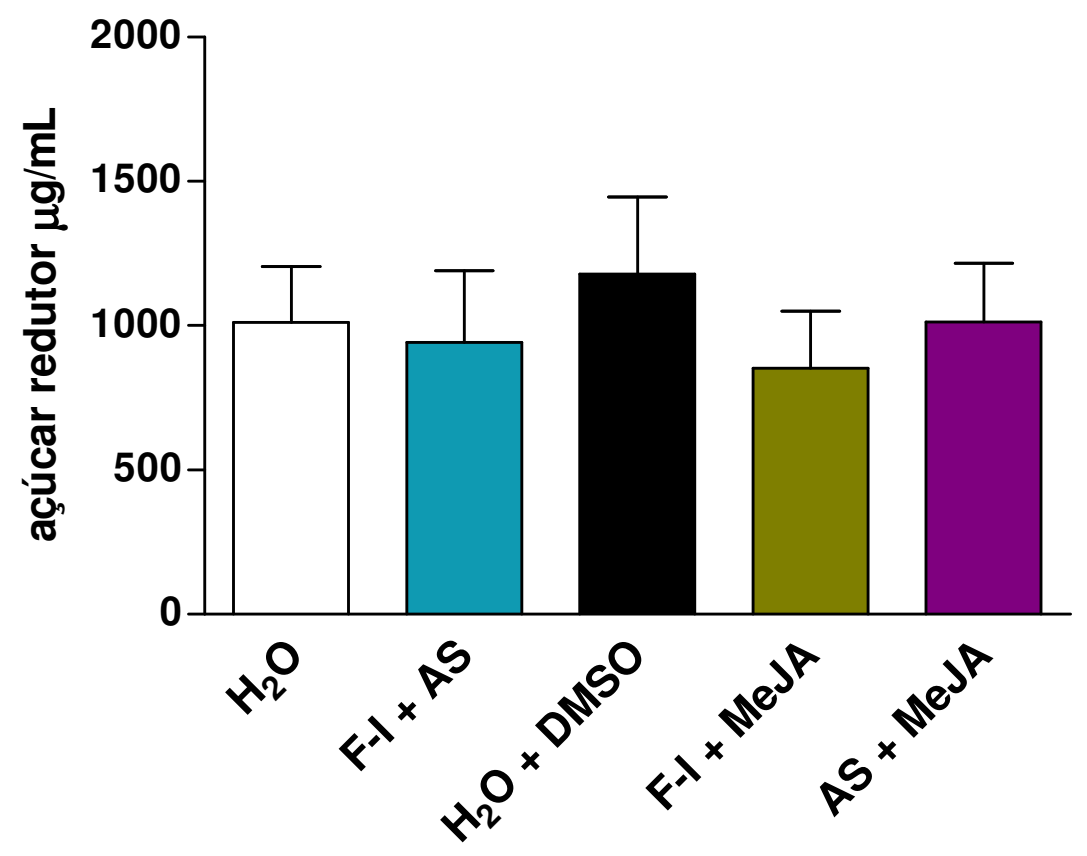

Figura 27. Teor de açúcar redutor em cultura de células de $R$. fruticosus com 60 minutos de elicitação; células de 18 dias, $8 \times 10^{4}$ cél. $/ \mathrm{mL}$ em $25 \mathrm{~mL}$ de amostra; F-I + AS, $\mathrm{F}-\mathrm{I}+$ MeJA e AS + MeJA [1000 nmol/L]; $(\mathrm{n}=6)$. Os resultados foram submetidos a um teste não-paramétrico do tipo análise da variância de uma via, seguido pelo pós-teste de Tukey. 
Oligossacarídeos de fungos e polissacarídeos de parede celular de classes de plantas são conhecidos por induzir respostas de defesa em baixas concentrações, da ordem de $\mathrm{nmol} / \mathrm{L}$. Uma classes de moléculas que tem comprovado envolvimento nessas respostas são oligogalacturonídeos (OGAs), que são moléculas elicitoras derivadas de polissacarídeos pécticos da parede celular de plantas (D'OVIDIO et al., 2004; NURNBERGER et al., 2004; NURNBERGER; SCHEEL, 2001). Estudos em folhas de tomate demonstraram que os OGAs são gerados por poligalacturonases que, por sua vez, são induzidas por lesões, as quais conduzem a produção de EROs, principalmente o $\mathrm{H}_{2} \mathrm{O}_{2}$ que pode atuar como um segundo mensageiro para genes de defesa em plantas (OROZCO-CÁRDENAS; NARVÁES-VÁSQUES; RYAN, 2001).

4.8. Caracterização, por CLAE, dos carboidratos componentes da fração S obtida das células de $\boldsymbol{R}$. fruticosus elicitadas com AS, F-I, MeJA, F-I + AS, F-I + MeJA e AS + MeJA

Com o objetivo de realizar uma análise cromatográfica mais sensível à detecção de açúcares liberado para o meio extracelular, foi realizado um estudo de caracterização, por CLAE, das frações sobrenadante de todas as amostras.

As frações $S$ foram aplicadas em cromatógrafo a líquido de alta eficiência (CLAE) e as amostras foram monitoradas por detector de índice de refração. Os resultados foram analisados utilizando padrões de massa molecular.

Através dos resultados apresentados pela tabela 2 podemos ter um perfil dos açúcares liberados no meio extracelular pelas amostras elicitadas pelo MeJA, AS e F-I e seus controles. A elicitação com F-I apresenta um dissacarídeo com $99,43 \%$ do total de açúcares e traços do trissacarídeo. O mesmo perfil de 
açúcares foi encontrado para o AS, apresentando 99,35\% em dissacarídeos. O controle para estes dois elicitores, a água, também mostrou a presença de dissacarídeos, e em menor quantidade $(52,47 \%)$. Além disso, no controle $\mathrm{H}_{2} \mathrm{O}$ foi verificado a presença de pentassacarídeos, com 46,98\%, diferentemente do F-I e AS.

Um tetrassacarídeo foi encontrado em grande quantidade com MeJA (93,42\% dos açúcares em 6'80') e como um traço com AS (0,36\%). Por último, o controle com DMSO apresentou um pico grande em 9'50" (94,06\%) característico de pentassacarídeos. Os grupos elicitados com MeJA e o seu controle também apresentaram açúcares menores em pequenas quantidades.

As amostras com F-I e AS induziram a liberação de dissacarídeo. Enquanto que, as amostras com MeJA induziram a liberação de açúcares maiores. Acredita-se que todos esses sacarídeos são conseqüências dos eventos moleculares que acontecem na parede celular durante as respostas de defesa.

Tabela 2 - Açúcares extracelulares liberados em elicitações com AS, F-I e MeJA. Porcentual das áreas dos picos, em relação às áreas totais, das leituras de amostras através de uma corrida cromatográfica em cromatografia a líquido de alta eficiência.

\begin{tabular}{ccccccc}
$\begin{array}{c}\text { Tempo de } \\
\text { Retenção }\end{array}$ & PICO & $\begin{array}{c}\mathbf{H}_{2} \mathrm{O} \\
\%\end{array}$ & $\begin{array}{c}\text { F-I } \\
\%\end{array}$ & $\begin{array}{c}\text { AS } \\
\%\end{array}$ & $\begin{array}{c}\text { DMSO } \\
\%\end{array}$ & $\begin{array}{c}\text { MeJA } \\
\%\end{array}$ \\
\hline 3' $45^{\prime \prime}$ & DISSACARÍDEO & 52,47 & 99,43 & 99,35 & 5,80 & 6,58 \\
5' $55^{\prime \prime}$ & TRISSACARÍDEO & 0,55 & 0,57 & 0,29 & 0,14 & - \\
6' $80^{\prime \prime}$ & TETRASSACARÍDEO & - & - & 0,36 & - & 93,42 \\
9' $50 "$ & PENTASSACARIDEO & 46,98 & - & - & 94,06 & -
\end{tabular}


Os resultados apresentados na Tabela 3 são referentes aos açúcares, liberados no meio extracelular, das amostras elicitadas pelas misturas dos elicitores. O dissacarídeo foi encontrado novamente para estas elicitações sendo que, o F-I + AS foi o que apresentou a maior quantidade $(78,65 \%)$, seguido pela água $(52,47 \%)$. O teor de dissacarídeo para a mistura F-I + AS mostrou-se próximo dos teores de dissacarídeos encontrados para as elicitações com AS e F-I isolados. Além disso, o pico com tempo de retenção de 9'50", referentes a pentassacarídeos foi predominante nas duas outras misturas de elicitores, 91,32\% para F-I + MeJA e 81,80\% para AS + MeJA. Este pico também foi predominante controle destas amostras $\left(\mathrm{H}_{2} \mathrm{O}+\right.$ DMSO com $\left.99,11 \%\right)$, e no controle DMSO $(94,06 \%)$ do MeJA. O F-I + AS mostrou este pico, porém em pequena quantidade $(20,62 \%)$, assim como a água $(46,98 \%)$.

Os dissacarídeos foram encontrados em pequenas quantidades nas misturas $\mathrm{F}-\mathrm{I}$ + MeJA (8,32\%) e AS + MeJA (17,82\%) mostrando que há uma predominância na liberações de açúcares maiores, como aconteceu para o grupo com MeJA.

Tabela 3 - Açúcares extracelulares liberados em elicitações com F-I + AS, F-I + MeJA e AS + MeJA. Porcentual das áreas dos picos, em relação às áreas totais, das leituras de amostras através de uma corrida cromatográfica em cromatrografia a líquido de alta eficiência.

\begin{tabular}{ccccccc}
$\begin{array}{c}\text { Tempo } \\
\text { de } \\
\text { Retenção }\end{array}$ & PICO & $\begin{array}{c}\mathrm{H}_{2} \mathbf{O} \\
\%\end{array}$ & $\begin{array}{c}\text { F-I+AS } \\
\%\end{array}$ & $\begin{array}{c}\mathrm{H}_{2} \mathrm{O}+\text { DMSO } \\
\%\end{array}$ & $\begin{array}{c}\text { F-I + MeJA } \\
\%\end{array}$ & $\begin{array}{c}\text { AS + MeJA } \\
\%\end{array}$ \\
\hline 3' 45" & DISSACARÍDEO & 52,47 & 78,65 & - & 8,32 & 17,82 \\
5' 55" & TRISSACARÍDEO & 0,55 & 0,73 & 0,22 & 0,18 & 0,38 \\
6' 80" & TETRASSACARÍDEO & - & - & 0,67 & 0,18 & - \\
9' 50" & PENTASSACARIDEO & 46,98 & 20,62 & 99,11 & 91,32 & 81,80
\end{tabular}


As análises realizadas para verificar os tipos de oligossacarídeos liberados pelos elicitores mostraram que há diferenças entre os tamanhos dos oligossacarídeos dependendo do tipo de elicitor adicionado. A parede celular vegetal não é simplesmente um exoesqueleto estático e inerte, mas serve também como uma matriz extracelular que interage com as proteínas da superfície celular, propiciando informações sobre desenvolvimento e posição. Em alguns casos, as moléculas derivadas das paredes também podem atuar como sinalizadoras para informar à célula sobre condições ambientais, como a presença de patógenos, sendo este um aspecto muito importante na defesa das plantas contra microrganismos invasores (ROSE; BENETT, 1999).

Enzimas específicas como glicosidases acabam clivando ligações entre os açúcares da parede celular (COSGROVE, 2001). A indução da atividade destas enzimas por parte das moléculas elicitoras estudadas poderia ser o motivo da presença destes açúcares encontrados no meio extracelular.

As elicitações com AS e com F-I demonstraram uma maior liberação de açúcares menores para o meio extracelular. O MeJA parece induzir a liberação de açúcares maiores. A degradação das paredes celulares pode resultar na produção de fragmentos de moléculas biologicamente ativas, denominadas de oligossacarinas, que podem estar envolvidas nas respostas de defesa ou de desenvolvimento (expansão celular) (JOHN et al., 1997). Uma interessante característica dos oligossacarídeos que exibem resposta de defesa é o baixo grau de especificidade estrutural referente ao tamanho do polímero (ALDINGTON, 1991). Isso torna possível que muitos outros tipos de fragmentos de polissacarídeos da parede celular das plantas exerçam uma resposta de defesa nas células (VORWERK; SOMERVILLE, S.; SORMEVILLE, C., 2004). 


\subsection{Análise do teor de proteínas liberadas para o meio extracelular em células de $R$. fruticosus elicitadas com AS, F-I, MeJA e suas misturas}

A liberação de açúcares para o meio extracelular pode estar relacionada à indução da atividade de enzimas específicas pelos elicitores. Estas enzimas atuariam clivando os polissacarídeos da parede celular e levando a formação de oligossacarídeos que, por sua vez, participam nos mecanismos de resistência das plantas. Portanto, foi realizada a análise do teor de proteínas na fração sobrenadante das amostras.

Os grupos elicitados por AS, F-I e MeJA (Figuras 28 e 29) manifestaram pouca diferença na liberação de proteína para o meio extracelular, quando comparada com os seus controles. O grupo elicitado com AS apresentou uma pequena inibição na liberação de proteína (7\%) em relação ao seu controle, mas não apresentou significância estatística.

Analisando as quantidades médias de proteínas dos grupos elicitados e dos grupos controle, podemos dizer que há diferenças significativas apenas para o grupo elicitado com a mistura composta por AS + MeJA, mostrando uma liberação de proteínas aproximadamente $9 \%$ superior ao seu controle (Figura 30). Ainda, as outras misturas de elicitores também mostraram serem indutoras, sendo que o grupo $\mathrm{F}-\mathrm{I}+$ MeJA foi mais indutor (4,5\%) do que o grupo $\mathrm{F}-\mathrm{I}+\mathrm{AS}$ $(1,5 \%)$. Porém, os efeitos indutores para estas duas misturas não foram relevantes (Figura 31). 


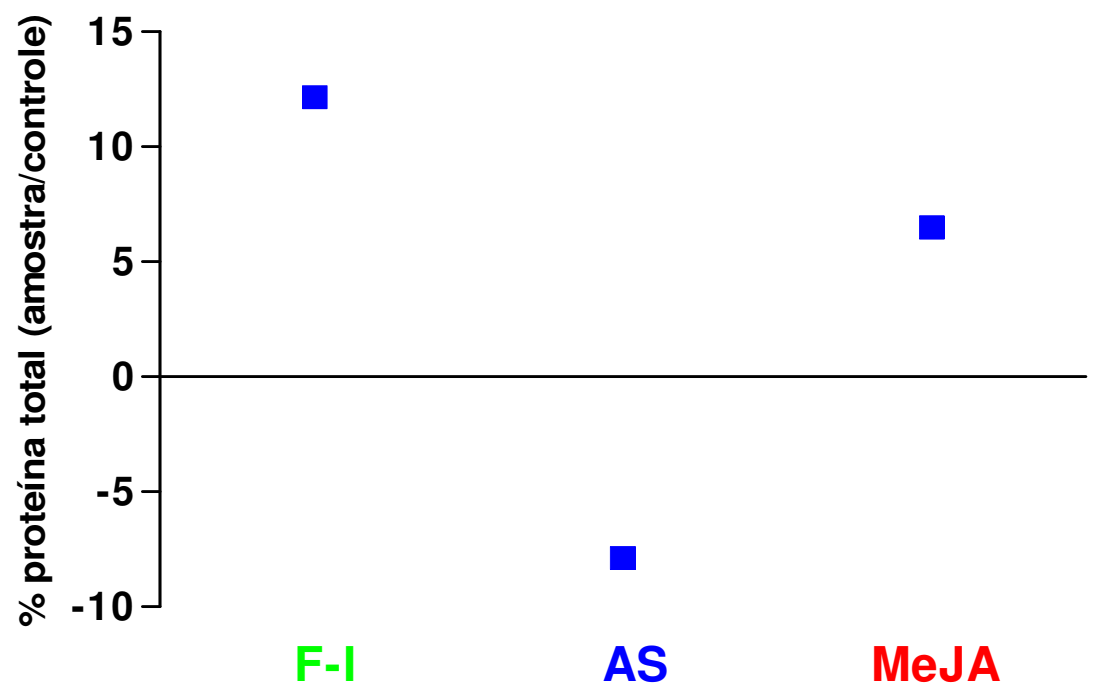

Figura 28. Porcentagem (\%) de proteína total das amostras elicitadas com F-I, AS e MeJA [1000 nmol/L] em relação ao controle para a fração sobrenadante (fração S) de ensaios de elicitação de cultura de células de $R$. fruticosus, com tempo de elicitação de 60 minutos.



Figura 29. Teor de proteína total em cultura de células de $R$. fruticosus com 60 minutos de elicitação; células de 18 dias, $8 \times 10^{4}$ cél. $/ \mathrm{mL}$ em $25 \mathrm{~mL}$ de amostra; F-I, AS e MeJA [1000 nmol/L]; $(n=6)$. Os resultados foram submetidos a um teste não-paramétrico do tipo análise da variância de uma via, seguido pelo pós-teste de Tukey. 


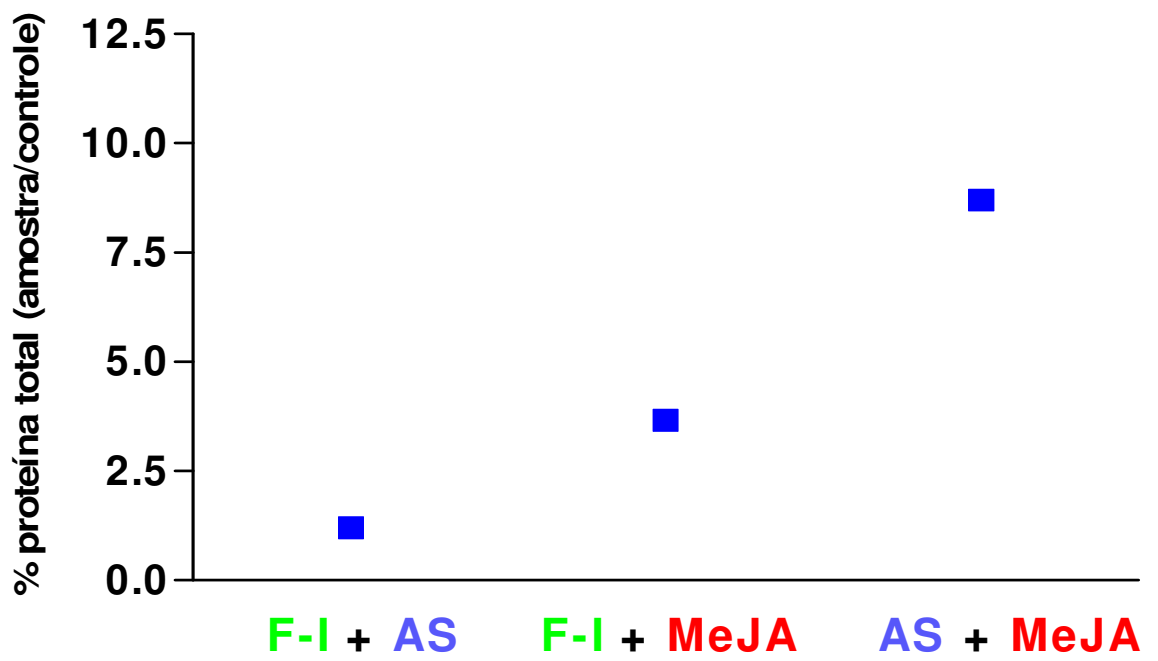

Figura 30. Porcentagem (\%) de proteína total das amostras elicitadas com F-I + AS, $\mathrm{F}-\mathrm{I}+\mathrm{MeJA}$ e AS + MeJA [1000 nmol/L] em relação ao controle na fração sobrenadante (fração $S$ ) de ensaios de elicitação de cultura de células de $R$. fruticosus, com tempo de elicitação de 60 minutos.



Figura 31. Teor de proteína total em cultura de células de $R$. fruticosus com 60 minutos de elicitação; células de 18 dias, $8 \times 10^{4}$ cél./mL em $25 \mathrm{~mL}$ de amostra; F-I +AS, $\mathrm{F}-\mathrm{I}+\operatorname{MeJA}$ e AS + MeJA [1000 nmol/L]; $(\mathrm{n}=6) . *(\mathrm{p}<0,05)=$ nível de significância em relação a $\mathrm{H}_{2} \mathrm{O}+\mathrm{DMSO}$ (controle). Os resultados foram submetidos a um teste nãoparamétrico do tipo análise da variância de uma via, seguido pelo pós-teste de Tukey. 
As análises do teor de proteína das amostras revelaram que a mistura AS + MeJA induziu um aumento na teor de proteína total liberada para o meio extracelular em cultura de células de $R$. fruticosus. As proteínas estão envolvidas em muitos eventos celulares relacionados a mecanismos de defesa. Após a percepção do ataque do patógeno, as células hospedeiras sintetizam várias moléculas incluindo EROs, proteínas quinases e fatores de transcrição, transmitindo o sinal para ativar as cascatas das vias sinalizadoras de resposta de defesa (KOTCHONI; GACHOMO, 2006). O reforço estrutural da parede celular envolve um grande polímero de várias glicoproteínas, ricas em hidroxiprolina, formado pelo "cross-linking" de proteínas da parede celular com a matriz de polissacarídeos (ALVAREZ et al., 1998).

Alguns elicitores, como oligogalacturonídeos podem induzir a fosforilação de proteínas (REYMOND et al, 1995). O aumento no teor de proteínas por AS + MeJA pode ter sido conseqüência da síntese das diversas proteínas envolvidas nas respostas de defesa das plantas.

Entre as possíveis famílias de proteínas induzidas pela elicitação com a mistura AS + MeJA estão as proteínas antioxidantes, as quais podem determinar um aumento na velocidade de degradação das EROs e, conseqüentemente, uma diminuição na detecção das EROs e $\mathrm{H}_{2} \mathrm{O}_{2}$ encontrados em nossos experimentos.

O ácido jasmônico induz a expressão de genes de defesa de plantas responsáveis pela síntese de proteínas específicas induzidas por jasmonatos (SLESAK, E.; SLESAK, M.; GABRYS, 2001). Três genes de tabaco (NtPat), previamente isolados, que codificam proteínas da família da patativa, tornam-se rapidamente induzidos durante a $\mathrm{RH}$, para o vírus mosaico do tabaco, devido ao acúmulo de jasmonato (DHONDT et al., 2002). 
Então, outros mecanismos, que direcionam para a inibição metabólica, devem acontecer para que ocorra uma repressão pelo AS das respostas que são dependentes do ácido jasmônico em algumas situação. Em Arabidopsis infectadas com o fungo Alternaria brassicicola ou tratadas com moduladores, tem sido relatado que 55 genes foram co-regulados por AS e MeJA, indicando que conexões positivas e negativas existem nas vias sinalizadoras de respostas de defesa (DHONDT et al., 2002).

\subsection{Análise do efeito de AS, F-I e MeJA e suas misturas sobre os componentes da parede celular de R. fruticosus}

As diferentes elicitações podem determinar mudanças na composição de monossacarídeos, componentes dos polímeros da parede celular, por induzirem a ativação de diferentes vias sinalizadoras. Sendo assim, foi desenvolvida a análise do efeito dos elicitores e das misturas de elicitores sobre a fração $P$ da parede celular.

As amostras da parede celular, fração $\mathrm{P}$, obtida a partir da elicitação com os diferentes indutores foram pesadas como mostram as Tabelas 4 e 5 .

Observa-se que não há grande variação entre as massas de paredes obtidas com AS, F-I e seu controle água, porém quando agem concomitantemente há um aumento significativo da massa de parede isolada. Nos ensaios utilizando MeJA houve uma diminuição da massa de parede isolada em relação ao seu controle DMSO. 
Tabela 4 - Massa de parede celular obtida após os ensaios de elicitação com os elicitores.

\begin{tabular}{cccccc} 
elicitor & $\mathrm{H}_{2} \mathrm{O}$ & $\mathrm{F}-\mathrm{I}$ & $\mathrm{AS}$ & DMSO & MeJA \\
\hline $\begin{array}{c}\text { massa } \\
\text { (mg/amostra) }\end{array}$ & 104,3 & 105,0 & 106,3 & 150,0 & 119,7 \\
\hline
\end{tabular}

Tabela 5 - Massa de parede celular obtida após os ensaios de elicitação com as misturas de elicitores.

\begin{tabular}{cccccc} 
elicitor & $\mathrm{H}_{2} \mathrm{O}$ & $\mathrm{F}-\mathrm{I}+\mathrm{AS}$ & $\mathrm{H}_{2} \mathrm{O}+$ DMSO & $\mathrm{F}-\mathrm{I}+$ MeJA & AS + MeJA \\
\hline $\begin{array}{c}\text { massa } \\
\text { (mg/amostra) }\end{array}$ & 104,3 & 203,0 & 129,0 & 196,7 & 193,3 \\
\hline
\end{tabular}

A análise do efeito da mistura de elicitores, sobre a fração $P$, mostrou um comportamento semelhante entre as três misturas ensaiadas, onde há um aumento da massa isolada. Esse comportamento pode sugerir um processo de reforço da parede. As análises de GLC das amostras da fração $P$ não apresentaram diferenças detectáveis no teor dos diferentes monossacarídeos componentes dos polímeros da parede celular. 
- Considerando os resultados dos experimentos de padronização, do método de detecção de espécies reativas de oxigênio, podemos verificar que é necessária a incubação de 20 minutos com $0 \mathrm{H}_{2} \mathrm{DCF}-\mathrm{DA} 2 \mu \mathrm{mol} / \mathrm{L}$, para este modelo adotado;

- Os resultados sugerem que os elicitores AS, F-I e MeJA modulam as vias que controlam a liberação de EROs em cultura de células de Rubus fruticosus. O polissacarídeo F-I e o AS aumentam a liberação de EROs; o que se repete quando é analisado a presença de $\mathrm{H}_{2} \mathrm{O}_{2}$ no sistema. $\mathrm{O}$ MeJA é pouco efetivo nesses processos;

- Quando são analisados os efeitos concomitantes de 2 elicitores verificamos que há uma alteração de seus efeitos em relação a sua presença isolado no meio de reação principalmente para a mistura $A S+M e J A$, que passa a ter um efeito altamente inibitório, sendo que o AS isolado é ativador da produção de $\mathrm{ERO}$ e e $\mathrm{H}_{2} \mathrm{O}_{2}$. A produção de EROs ativada por $\mathrm{F}$-I também passa a ser inibida na presença de MeJA;

- Os resultados de açúcar redutor e análise por CLAE dos meios extracelulares, após a ação dos elicitores e as suas misturas sobre as células de R. fruticosus, demonstraram que esses modulam a liberação de componentes da parede celular. As células elicitadas com F-I apresentam no meio extracelular maior teor de açúcar redutor seguido por AS e este teor é composto principalmente por dissacarídeos. Por outro lado, o MeJA causa uma pequena diminuição nos teores de açúcar redutor em relação ao seu controle, sendo composto por oligossacarídeos de maior massa molecular; 
- As misturas de elicitores levaram a uma diminuição da liberação de açúcares redutores no meio extracelular, o que é confirmado pela predominância de oligossacarídeos de maior massa molecular;

- Em relação aos resultados de proteína total, podemos dizer que a quantidade de proteína liberada, durante a elicitação, foi alterada pela presença da mistura de elicitores AS + MeJA;

- Portanto, os resultados sugerem um efeito ativador de $\mathrm{EROs} \mathrm{e} \mathrm{H}_{2} \mathrm{O}_{2}$ por F-I e AS, os quais causam uma liberação de fragmentos de parede, principalmente de dissacarídeos, que provavelmente representam apenas degradação desta parede. Entretanto, na presença de MeJA há uma pequena produção de $\mathrm{ERO}$ e $\mathrm{H}_{2} \mathrm{O}_{2}$ e há um aumento da liberação de fragmentos de maior massa molecular que podem ter a função de sinalizadores para o espessamento da parede, liberação de enzimas e de outras moléculas de defesa no sistema. Quando do efeito concomitante de dois elicitores, verificou-se o efeito inibitório na produção de EROs causado por MeJA, na mistura AS + MeJA, e esta inibição causa o mesmo padrão de liberação de açúcares no meio extracelular. 
REFERÊNCIAS 
AIST, J.R.; BRUSHNELL, W.R. Invasion of plants by powdery mildew fungi, and cellular mechanisms of resistance; in: COLE, G.T.; HOCH, H.C. (Eds). The fungal spore and disease interaction in plants and animals. New York, Plenium Press, 1991, p. 321345.

ALDINGTON, S. Structure-activity relationships of biologically active oligosaccharides. Plant Cell and Environment, v. 14, p. 625-636, 1991.

ALLAN, A.C.; FLUHR, R. Two distinct sources of elicited reactive oxygen species in tobacco epidermal cells, Plant Cell, Rockville, v. 9, n9 9, p. 1559-1572, 1997.

ALVARES, M.E. Salicylic acid in the machinery of hypersensitive cell death and desiese resistance. Plant Molecular Biology, Netherlands, v. 44, p. 429-442, 2000.

ALVAREZ, M.E.; PENNELL, R.I.; MEIJER, P.J.; ISHIKAWA, A.; DIXON, R.A.; LAMB, C. Reactive oxygen intermediates mediate a systemic signal network in the establishment of plant immunity. Cell, Cambridge, v. 92, p. 1-20, 1998.

ANDI, S.; TAGUCHI, F.; TOYODA, K.; SHIRAISHI, T.; ICHINOSE, Y. Effect of methyl jasmonate on harpin-induced hypersensitive cell death, generation of hydrogen peroxide and expression of PAL mRNA in tobacco suspension cultured BY-2 cells. Plant Cell Physiology, Tokyo, v. 42, n. 4, p. 446-449, 2001.

APEL, K.; HIRT, H. Reactive oxygen species: Metabolism, oxidative stress, and signal transduction. Annual Review Plant Physiology and Plant Molecular Biology, Palo Alto-CA, v. 55, p. 373-399, 2004.

APOSTOL, I.; HEINSTEIN, P.F.; LOW, P.S. Rapid stimulation of an oxidative burst during elicitation of cultures plant cell. Plant Physiology, Lancaster, v. 90, p. 109-116, 1989.

ASADA, K.; TAKAHASHI, M. Production and scavenging of active oxygen in photosynthesis. In: KYLE, D.J.; OSMOND, C.B.; ARNTZEN, C.J. (Eds). Photoinhibition. $1^{\text {rd }}$ editon. Elsevier, Amsterdam, p. 227-287, 1987.

BAKER, C.J.; O'NELL, N.R.; KEPPLER, L.D.; ORLANDI, E.W. Early responses during plant-bacterial interactions in tobacco cell suspensions. Phytopathology, St. Paul, v. 81, p. 1504-1507, 1991.

BAKER, C.J.; ORLANDI, E.W. Active oxygen and pathogenesis in plants. In STACEY, G \& KEEN, N.T. (Eds). Plant Microbe Interactions, St. Paul, Minnesota. APD Press, 1999, p. 81-119.

BAKER, C.J.; ORLANDI, E.W. Active oxygen in plant pathogenesis. Annual Review of Phytopathology, Palo Alto-CA, v. 33, p. 299-321, 1995.

BANERJEE, A.K.; MANDAL, A.; CHANDA, D.; CHAKRABORTI, S. Oxidant, antioxidant and physical exercise. Molecular and Cellular Biochemistry, v. 253, n. 1-2, p. 307-312, 2003.

BARBER, M.S.; BERTRAM, R.E.; RIDE, J.P. Chitin oligossacharides elicit lignification in wounded wheat leaves. Physiological and Molecular Plant Pathology, London, v. 34, p. 3-12, 1989.

BARJA, G. The Quantitative Measurement of $\mathrm{H}_{2} \mathrm{O}_{2}$ generation in isolated mitochondria. Jornal of Bioenergetics and Biomembranes, Madrid, v. 34(3), p. 227-233, 2002. 
BARTELS, D. Targeting detoxification pathways: an efficient approach to obtain plants with multiple stress tolerance? Trends Plant Science, Kidlington, v. 6, p. 284-286, 2001.

BEERS, E.P.; McDOWELL, J.W. Regulation and execution of programmed cell death in response to pathogens, stress and development crues. Current Opinion in Plant Biology, v. 4, p. 561-567, 2001.

BELESKI-CARNEIRO, E.B.; GANTER, J.L.M.S.; REICHER, F. Structural aspects of exudate from the fruit of Chorisia speciosa. St. Hil. International Journal Biological Macromolecules, Guildford, v. 26, p. 219-224, 1999.

BELESKI-CARNEIRO, E.B.; SIERAKOWSKI, M.R.; GANTER, J.L.M.S.; ZAWADZKIBAGGIO, S.F.; REICHER, F. Polysaccharides from Chorisia speciosa. St. Hil. Progress in Biotechnolology: Pectins and Pectinases, New York, v. 14, p. 215 - 300, 1996.

BELESKI-CARNEIRO, E.B.; SUGUI, J. A.; REICHER, F. Structural and biological features of a hydrogel from seed coats of Chorisia speciosa. Phytochemistry, New York, v. 61 , p. $157-163,2002$.

BERGEY, D.; OROSCO-CARDENAS, M.; MOURA, D.S.; RYAN, C.A. A wound and systemin-inducible polygalacturonase in tomato leaves. Proceedings of National Academic Science, Washington DC, v. 46, p. 1756-1760, 1999.

BOLWELL, G.P. Role of active oxygen species and NO in plant defense responses. Current Opinion in Plant Biology, v. 2, p. 287-294, 1999.

BORSANI, O.; VALPUESTA, V.; BOTELLA, M.A. Developing salt tolerance plants in a new century: a molecular biology approach. Plant Cell, Tissue and Organ Culture, v. 73, p. 101-115, 2003.

BRADFORD, M.M. A rapid and sensitive method for the quantification of microgram quantities of protein utilizing the principle of protein-dye binding. Analytical Biochemistry, New York, v. 72, p. 248-254, 1976.

BREUSEGEM, F.V.; VRANOVÁ, E.; DAT. J.F.; INZÉ, D. The role of active oxygen species in plant signal transduction. Plant Science, Oxford, v. 161, p. 405-414, 2001.

BRISSON, L.F.; TENHAKEN, R.; LAMB, C. Function of oxidative cross-linking of cell wall structural proteins in plant disease resistance. Plant cell, Rockville, v. 6, p. 1703-1712, 1994.

BUCHANAN, B.B.; GRUISSEM, W.; JONES, R.L. (Eds). Biochemistry and Molecular Biology of Plants. $1^{\text {rd }}$ editon. Rockville, Maryland. ASP Press, 2000.

CARPITA, N.C.; GIBEAUT, D.M. Structural models of primary cell walls in flowering plants: consistency of molecular structure with the physical properties of the walls during growth. Plant Journal: for cell and molecular biology, Oxford, v. 3, n. 1, p. 1-30, 1993.

CARPITA, N.C. Structure and biogenesis of the cell walls of grasses. Annual Review of Plant Physiology Plant Molecular Biology, Indiana,v. 47, p. 445-476, 1996.

CHANLIAUD, E.; DE SILVA, J.; STRONGITHARM, B.; JERONIMIDIS, G.; GIDLEY, M.J. Mechanical effects of plant cell wall enzymes on cellulose/xyloglucan composites. Plant Journal, Oxford, v. 38, n. 1, p. 27-37, 2004. 
CLARKE, A.; DESIKAN, R.; HURST, R.D.; HANCOCK, J.T.; NEILL, S.J. NO way back: nitric oxide and programmed cell death in Arabidopsis thaliana suspension cultures. Plant Journal, Oxford, v. 24, p. 667-677, 2000.

CLEMENTS, M.; SAFFREY, J. Cell communication. In: SAFFREY, J. (Ed.). The Core of Life, The Open University, Milton Keynes, 2001, v. II, 2001.

CONRATH, U.; PIETERSE, C.M.J.; MAUCH-MANI, B. Priming in plant-pathogen interaction. Trends Plant Science, Kidlington, v. 7, p. 110-116, 2002.

COSGROVE, D. J. Expansive growth of plant cell walls. Plant Physiology and Biochemistry, New Delhi, v. 38, v. 38, n1/2, p. 109-124, 2000.

COSGROVE, D. J. Wall structure and wall loosening. A look backwards and forwards. Plant Physiology, Rockville, v. 125, p. 131-134, 2001.

COSGROVE, D.J. Growth of the plant cell wall. Nature Reviews Molecular Cell Biology, v. 6, n. 11, p. 850-861, 2005.

COSIO, E.G.; FEGER, M.; MILLER, C.; ANTELO, L.; EBEL, J. High affinity binding of a synthetic heptaglucoside and fungal glucan elicitors to cell membranes of species of the plant family Fabaceae. Planta, New York, v. 200, p. 92-95, 1996.

DANGL, J.F.; DIETRICH, R.A.; THOMAS, H. Senescence and Programmed Cell Death. In: BUCHANAN, B.B.; GRUISSEM, W.; JONES, R.L. (Eds). Biochemistry and Molecular Biology of Plants. Rockville, Maryland. ASP Press, 2000, Chapter 20, p. 1044-1101.

DAT, J.; VANDENABEELE, S.; VRANOVÁ, E.; VAN MANTAGNU, M.; INZÉ, D.; VAN BREUSEGEM, F. Dual action of active oxygen species during plant stress responses. Cellular and Molecular Life Science, v. 57, p. 779-795, 2000.

DAVLETOVA, S.; RIZHSKY, L.; LIANG, H.; SHENGGIANG, Z.; OLIVER, D.J.; COUTU, J.; SHULAEV, V.; SCHLAUCH, K.; MITTLER, R. Cytolosic ascorbate peroxidase 1 is a central component of the reactive oxygen gene network of Arabidopsis. Plant Cell, Rockville, v. 17, p. 268-281, 2005.

DELANEY, T.P.; UKNES, S.; VERNOOJJ, B.; FRIEDRICH, L.; WEYMANN, K.; NEGROTTO, D.; GAFFINE, T.; GUT-RELLA, M.; KESSMANN, H.; WARD, E.; RYALS, J. A central role of salicylic acid in plant disease resistance. Science, Wasshington DC, v. 266, p. 1247-1250, 1994.

DELLEDONNE, M.; ZEIER, J.; MARROCO, A.; LAMB, C. Signal interactions between nitric oxide and reactive oxygen intermediates in the plant hypersensitive disease resistance response. Proceedings of National Academic Science, Washington DC, v. 98, p. 13454-13459, 2001.

DE SOUZA, W.R. Estudo do efeito elicitor do ácido salicílico e do polissacarídeo extraído de sementes de paineira (Chorisia speciosa) em cultura de células de amora-preta (Rubus fruticosus). 2005. 97p. Dissertação (Mestrado em Ciências Farmacêuticas - Fármacos e Medicamentos) - Faculdade de Ciências Farmacêuticas Universidade de São Paulo, Ribeirão Preto, 2005. 
DHONDT, S.; GOUZERH, G.; MULLER, A.; LEGRAND, M.; HEITZ, T. Spatio-temporal expression of patatin-like lipid acyl hydrolases and accumulation of jasmonates in elicitortreated tobacco leaves are not affected by endogenous levels of salicylic acid. The Plant Journal, Oxford, v. 32, p. 749-762, 2002.

DINAND, E.; EXCOFFIER, G.; LIÉNART, Y.; VIGNON, M.R. Two rhamnogalacturonide tetrasaccharides isolated from semi-retted flax fibers are signaling molecules in Rubus fruticosus L. Cell. Plant Physiology, Lancaster, v. 115, p. 793-801, 1997.

DOARES, S.H.; SYROVETS, T.; WEILER, E.W.; RYAN, C.A. Oligogalacturonides and chitosan activate plants defensive genes through the octadecanoid pathway. Proceedings of National Academic Science, Washington DC, v. 93, p. 4095-4098, 1995.

DOKE, N.; MUIRA, Y. In vitro activation of NADPH-dependent $\mathrm{O}_{2}$ generation system in a plasma membrane-rich fraction of potato tuber tissues by treatment with an elicitor from Phytophthora infestans or with digitonin. Physiological and Molecular Plant Pathology, London, v. 46, p. 17-28, 1995.

DOKE, N. The oxidative burst: roles in signal transduction and plant stress. In: Scandalios, J.G. (Eds). Oxidative stress and the molecular biology of antioxidant defense. New York, Cold Spring Harbor Laboratory Press, 1997, p. 785-813.

DONG, Y.H.; ZHAN, X.C.; KVARNHEDEN, A.; ATKINSON, R.G.; MORRIS, B.A.; GARDNER, R.C. Expression of a cDNA from apple encoding a homologue of DAD1, an inhibitor of programmed cell death. Plant Science, Oxoford, v. 139, p. 165- 174, 1998.

D'OVIDIO, R.; MATTEI, B.; ROBERTI, S.; BELLINCAMPI, D. Polygalacturonases, polygalacturonase-inhibiting proteins and pectic oligomers in plant-pathogen interactions. Biochimica et Biophysica Acta, Amsterdam, v. 1696, p. 237-244, 2004.

DURNER, J.; WENDEHENNE D.; KLESSIG, D.F. Defense gene induction in tobacco by nitric oxide, cyclic GMP and cyclic ADP-ribose. Proceedings of National Academic Science, Washington DC, v. 95, p. 10328-10333, 1998.

FARMER, E.E.; MOLOSHOK, T.D.; SAXTON, M.J.; RYAN, C.A. Oligosaccharide signaling in plants. Specificity oligouronide-enhanced plasma membrane protein phosphorilation. Journal of Biology and Chemistry., Baltimore, v. 266, p. 3140-3145, 1991.

FLOR, H.H. Host-parasite interaction in flax rust. Its genetics and other implications. Phytopathology, St. Paul, v. 45, p. 680-685, 1955.

FOREMAN, J.; DEMIDCHIK, V.; BOTHWELL, J.H.F.; MYLONA, P.; MIEDEMA, H.; TORRES, M.A.; LINSTEAD, P.; COSTA, S.; BROWNLEE, C.; JONES, J.D.G. Reactive oxygen species produced by NADPH oxidase regulate plant cell growth. Nature, London, v. 422, p. 422-446, 2003.

FOSKET, D.E. Characteristics of plant cells that are important in development. Plant Growth and Development: A Molecular Approach Academic Press, San Diego, 1994, p. 198-273.

FOYER, C.H.; LELANDAIA, M.; KUNERT, K.J. Photo oxidative stress in plants. Physiologia Plantarum, Warszawa, Poland, v. 92, p. 696-717, 1994. 
FOYER, C.H.; NOCTOR, G. Redox homeostasis and antioxidant signaling: a metabolic interface between stress perception and physiological responses. Plant Cell, Rockville, v. 17, p. 1866-1875, 2005.

GERSHENZON, J. Secondary Metabolites and Plant Defense. In: TAIZ, L.; ZEIGER, E. (Eds). Plant Physiology. $3^{\text {rd }}$ edition. Sunderland, Sinauer Associates Inc., 2002. Chapter 13, p. 283-308.

GUO, F-Q.; OKAMOTO, M.; CRAWFORD, N.M. Identification of a plant nitric oxide synthase gene involved in hormonal signalling. Science, Oxford, v. 302, p. 100-103, 2003.

HADWIGER, L.A.; BECKMAM, J. Chitosan as component of pea-Fusarium solani interactions. Plant Physiology, Lancaster, v. 66, p. 205-211, 1980.

HAMMERSCHIMIDT, R. Phytoalexins: what have we learned after 60 years? Annual Review Phytopatology, Palo Alto-CA, v. 37, p. 285-306, 1999.

HAMMOND-KOSACK, K.E.; JONES, J.D.G. Resistance gene-dependent plant defense responses. Plant Cell, Rockville, v. 8, p. 1773-1791, 1996.

HAMMOND-KOSACK, K.E.; JONES, J.D.G. Response to Plant Pathogens. In: BUCHANAN, B.B.; GRUISSEM, W.; JONES, R.L. (Eds). Biochemistry and Molecular Biology of Plants. $1^{\text {rd }}$ editon. Rockville, Maryland. ASP Press, 2000. Chapter 21, p. 1102-1152.

HAYASHI, T. ; MARSDEN, M.P. ; DELMER, D.P. Xyloglucan and cellulose : VI ; xyloglucan-cellulose interactions in vitro and in vivo. Plant Physiology, Lancaster, v. 83, n. 2, 384-389, 1987.

HEATH, M.C. Hypersensitive response-related death. Plant Molecular Biology, Netherlands, v. 44, p. 321-334, 2000.

HELLER, R. Recherches sur la nutrition miné rale des tissus végétaux cultivés in vitro. Annuaire des Sciences Naturelles et Biologie Végétale, Paris, v. 14, p. 1-233, 1953.

HUSTACHE, G.; MOLLARD, A.; BARNOUD, F. Culture illimitée d'une souche anergiée de Rosa glauca par la technique des suspensions cellulaires. Comptes Rendus de I'Académie des Sciences, Paris, v. 281, p. 1381-1384, 1975.

INUI, H.; YAMAGUCHI, Y.; HIRANO, S. Elicitors actions of $\mathrm{N}$-acetiloligosaccahrides and laminarioligosaccharides for chitinase and L-phenylalanine ammonia-lyase induction in rice suspension culture. Bioscience, Biotechnology and Biochemistry, Tokyo, v. 61, p.975-978, 1997.

ISHIGAKI, E.; ASAMIZU, T.; ARISAWA, M.; KUROSAKI, F. Cloning and expression of calmodulin genes regulating phytoalexin production in carrot cells. Biological and Pharmaceutical Bulletin, v. 27, N.8, p. 1308-1311, 2004.

JARVIS, A.C.; McCANN, M.C. Macromolecular biophysics of plant cell wall: concepts and methodology. Plant Physiology and Biochemistry, New Delhi, v.38 (1/2), p.1-13, 2000. 
JOHN, M.; RÖHRIG, H.; SCHIMIDT, J.; WALDEN, R.; SCHELL, J. Cell signaling by oligosaccharides. Trends in Plant Science, Kidlington, v. 2, p. 111-115, 1997.

JONES, A. Does the plant mitochondrial integrate cellular stress and regulate programmed cell death? Trends in Plant Science, Kidlington, v. 5, p. 225-230, 2000.

KANAI, R.; EDWARDS, G.E. Purification of enzymatically isolated mesophyll protoplasts from C3, C4 and Crassulacean acid metabolism plants using an aqueous dextranpolyethylene glycol two phase system. Plant Physiology, Lancaster, v. 52, p. 484-490, 1973.

KAWANO, T.; PINONTOAN, R.; UOZUMI, N.; MIYAKE, C.; ASADA, K.; KOLATTUKUDY, P.E.; MUTO,S. Aromatic monoamine-induced immediate oxidative burst leading to an increase in cytosolic $\mathrm{Ca}^{2+}$ concentration in tobacco suspension culture. Plant Cell Physiology, Tokyo, v. 41, p. 1251-1258, 2000.

KEEGSTRA, K.; TALMADGE, K.W.; BAUER, W.D.; ALBERSHEIM, P. Structure of plant cell walls II. A model of the walls of suspension-cultured sycamore cells based on the interconnections of the macromolecular components. Plant Physiology, Lancaster, v. 51 , p. $188-197,1973$.

KEPPLER, L.D.; BAKER, C.L. O initiated lipid peroxidation in a bacteria-induced hypersensitive reaction in tobacco cell suspensions. Phytopathology, v. 79, p. 555-562, 1989.

KEPPLER, L.D.; BAKER, C.L.; ATKINSON, M.M. Active oxygen production during bacteria-induced hypersensitive reaction in tobacco suspension cells. Phytopathology, St. Paul, v. 79, p. 974-978, 1989.

KERR, J.F.R.; WYLLIE, A.H.; CURRIE, A. R. Apoptosis: a basic biological phenomenon with wide-ranging implications in tissue kinetics. British Journal of Cancer, v. 26, 239-257, 1972.

KHOKHLATCHEV, A.V.; CANAGARAJAH, B.; WILSBACHER, J.; ROBINSON, M.; ATKINSON, M.; GOLDSMITH, E.; COBB, M.H. Phosphorylation of the MAP kinase ERK 2 promotes its homodimerization and nuclear translocation. Cell, Cambridge, v. 93, p. 605-615, 1998.

KHURANA, S.M.P.; PANDEY, S.K.; SARKAR, D. Apoptosis in plant disease response: a close encounter of the pathogen kind. Current Science v. 88, p. 740-752, 2005.

KIDBY, D.K.; DAVIDISON, D.J. A convenient ferricyanide estimation of reducing sugars in the nanomole range. Analytical Biochemistry. v. 55, n.1, p. 321-325, 1973.

KIEFFER, F.; JHERMINIER, J.; SIMON-PLAS, F.; NICOLE, M.; PAYNOT, M.; ELMAYAN, T.; BLEIN, J. The fungal elicitor cryptogein induces cell wall modifications on tobacco cell suspension. Journal of Experimental Botany, Nagoia, v. 51, p. 1799-1811, 2000.

KLARZYNSKY, O.; PLESSE, B.; JOUBERT, J.M.; YVIN, J.C.; KOPP, M.; KLOAREG, B.; FRITIG, B. Linear $\beta-1,3$ glucans are elicitors of defense responses in tobacco. Plant Physiology, Lancaster, v. 124, p. 1027-1037, 2000.

KONG, H.Y.; JUNG, H.W.; LEE, S. C.; CHOI, D.; HWANG, B.K. A gene encoding stellacyanin is induced in Capsicum annuum by pathogens, methyl jasmonate, abscisic 
acid, wounding, drought and salt stress. Physiologia Plantarum, v. 115, n. 3, p.550-562, 2002.

KOTCHONI, S.O.; GACHOMO, E.W. The reactive oxygen species network pathways: an essential prerequisite for perception of pathogen attack and the acquired disease resistance in plants. Journal of Bioscience, v. 31, n. 3, p. 391-404, 2006.

KOVTUN, Y.; CHIU, W-L.; TENA, G.; SHEEN, J. Functional analysis of oxidative stressactivated mitogen-activated protein kinase cascade in plants. Proceedings of National Academy of Sciences of the United State or America, v. 97, p. 2940-2945, 2000.

LAMB, C.E.; DIXON, R.A. The oxidative burst implant disease resistance. Annual Review of Plant Physiology and Molecular Biology, Palo Alto, CA, v. 48, p. 251-275, 1997.

LAM, E.; KATO, N.; LAWTON, M. Programmed cell death, mitochondria and the plant hypersensitive response. Nature, London, v. 411, N. 6839, p. 848-853, 2001.

LEE, H.I.; LÉON, J.; RASKIN, I. Biosyntheses and metabolism of salicylic acid. Proceedings of National Academy of Sciences of the United State or America, Washington DC, v. 92, p. 4072-4079, 1995.

LEE, S.; CHOI, H.; SUH, S.; DOO, I.; OH, K.; CHOI, E.J.; TAYLOR, A.N.S.; LOW, P.S.; LEE, Y. Oligogalacturonic acid and chitosan reduce stomatal aperture by inducing the evolution of reactive oxygen species from guard cells of tomato and Commelina communis. Plant Physiology, Lancaster, v. 121, p. 147-152, 1999.

LIENART, Y; GAUTIER C.; DRIGUEZ, H. Immobilized sugars as abiotic inducers of

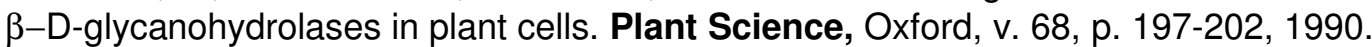

MAUCH, F.; MAUCH-MANI, B.; GAILLE, C.; KULL, B.; HAAS, D.; REIMMANN, C. Manipulation of salycilate content in Arabidopsis thaliana by the expression of an engineered bacterial salycilate synthase. Plant Journal, Oxford, v. 25, p. 67-77, 2001.

MAZAU, D.; ESQUERRÉ-TUGAYÉ, M.T. Hydroxyproline-rich glycoprotein accumulation in the cell walls in plants infected by various pathogens. Physiological and Molecular Plant Pathology, London, v. 29, p. 147-157, 1986.

McQUEEN-MASON, S. M.; COSGROVE, D. J. Disruption of hydrogen bonding between plant cell wall polymers by proteins that induce wall extension. Proceedings of National Academic Science, Washington DC, v. 91, n.14, p. 6754-6578, 1994.

McNEIL, M.; DARVILL, A.G.; FRY, S.C.; ALBERSHEIM, P. Structure and function of the primary cell wall of plants. Annual Review of Biochemistry, Stanford, CA, v. 53, p. 625663, 1984.

MELLERSH, D.G.; FOULDS, I.V.; HIGGINS, V.J.; HEATH, C.M. $\mathrm{H}_{2} \mathrm{O}_{2}$ plays different roles in determining penetration failure in three diverse plant-fungal interactions. Plant Journal, Oxford, v. 29, p. 257-268, 2002.

MITTLER, R. Oxidative stress, antioxidants, and stress tolerance. Trends Plant Science, Kidlington, v. 7, p. 405-410, 2002. 
MITTLER, R.; VANDERRAUWERA, S.; GOLLERY, M.; VAN BREUSEGEM, F. The reactive oxygen gene network of plants. Trends Plant Science, Kidlington, v. 9, p. 490498, 2004.

MOLLER, I.M. Plant mitochondria and oxidative stress: electron transport, NADPH turnover, and metabolism of reactive oxygen species. Annual Review Plant Physiology and Plant Molecular Biology, Palo Alto, CA, v. 52, p. 561-591, 2001.

MOON H.; LEE, B.; CHOI, G.; SHIN, D.; PRASAD, D.T.; LEE, O.; KWAT, S-S.; KIM, D.H.; NAM, J.; BAHK, J.; HONG, J.C.; LEE, S.Y.; CHO, M.J.; LIM, C.H. NDP kinase 2 interacts with two oxidative stress-activated MAPKs to regulate cellular redox state and enhances multiple stress tolerance in transgenic plants. Proceedings of National Academic Science, Washington DC, v. 100, p. 358-363, 2003.

MURATA, Y.; PEI, Z.-M.; MORI, I.C.; SCHOROEDER, J.I. Abscisic acid activation of plasma membrane $\mathrm{Ca}^{2+}$ channels in guard cells requires $\mathrm{NAD}(\mathrm{P}) \mathrm{H}$ and is differentially disrupted upstream and downstream of reactive oxygen species production in the abi1-1 and abi2-1 protein phosphatase 2C mutans. Plant Cell, Rockville, v. 13, p. 2513-2523, 2001.

NAVAZIO, L. The role of calcium in oligogalacturonide-activated signaling in soybean cells. Planta, New York, v. 215, p. 596-605, 2002.

NEILL, S.; DESIKAN, R.; HANCOCK, J. Hidrogen peroxide signalling. Current Opinion in Plant Biology, v. 5, p. 388-395, 2002.

NIMCHUK, Z.; EULGEM, T.; HOLT, B.F. 3rd.; DANGL, J.L. Recognition and response in the plant immune system. Annual Review of Genetics, Atlanta, v. 37, p. 579-609, 2003.

NITA-LAZAR, M.; CHEVOLOT, L.; IWAHARA, S.; TAKEGAWA, K.; FURMANEK, A.; LIÉNART, Y. High performance liquid chromatography and photodiode array detection of ferulic acid in Rubus protoplasts elicited by O-glycans from Fusarium sp. M7-1. Acta Biochimica Polonica, Warszawa, v. 48, p. 1019-1027, 2002.

NITA-LAZAR, M.; CHEVOLOT, L.; LIÉNART, Y. O-glycans isolated from Fusarium glycoproteins induce a PAL complex activity in raspberry protoplasts. Second International Electronic Conference on Synthesis Organic Chemistry, Sept., p. 1-30, 1998.

NITA-LAZAR, M.; HEYRAUD, A.; GEY, C.; BRACCINI, I.; LIENART,Y. Novel oligosaccharides isolated from Fusarium oxysporum L. rapidly induce PAL activity in Rubus cells. Acta Biochimica Polonica, Warszawa, v. 51, p. 625-634, 2004.

NOTHNAGEL, E.A.; McNEIL, M.; ALBERSHEIM, P.; DELL, A. Host-pathogen interactions. XXII: A galacturonic acid oligosaccaharide from plant cell walls elicits phytoalexins. Plant Physiology, Lancaster, v. 71, p. 916-926, 1983.

NURNBERGER, T.; BRUNNER, F.; KEMMERLING, B.; PIATER, L. Innate immunity in plants and animals: striking similarities and obvious differences. Immunological Reviews, Copenhagen, v. 198, p. 249-266, 2004.

NURNBERGER T.; SCHEEL D. Signal transmission in the plant immune response. Trends Plant Science, Kidlington, v. 6, p. 372-379, 2001. 
ODONELL, P.J.; CALVERT, C.; ATZON, R.; WASTERNACK, C.; LEYSER, H.M.O.; BOWLES, D.J. Ethylene as a signal mediating the wound response of tomato plants. Science, Wasshington DC, v. 274, p. 1914-1917, 1996.

O'NEILL, M. A.; EBERHARD, S.; ALBERSHEIM, P.; DARVILL, A.G. Requirement of borate cross-linking of cell wall rhamnogalacturonan for Arabidopsis growth. Science, Washington DC, v. 294, n. 5543, p. 846-849, 2001.

OROZCO-CÁRDENAS, M.L.; NARVÁES-VÁSQUES, J.; RYAN, C.A. Hydrogen peroxide acts as a second messenger for the induction of defense genes in tomato plants in response to wounding, systemin, and methyl jasmonate. The Plant Cell, v. 13, p. 179191, 2001.

PASCHOLATTI, S.F.; LEITE, B. Hospedeiro: Mecanismos de resistência. In: BERGAMIN FILHO, A., KIMATI, H., AMORIM, L. (Eds). Manual de Fitopatologia, v.1- Princípios e conceitos. 3a ed., São Paulo: Agronômica Ceres, 1995. Chapter 22, p.417-452.

PATIER, P.; POTIN, P.; ROCHAS, C.; KLOAREG, B.; YVIN, J.C.; LIENART, Y. Free or silica bound oligokappa-carragenans elicit laminarinase activity in Rubus cells and protoplasts. Plant Science, Shanon-Ireland, v. 10, p. 27-35, 1995.

PAVET, V.; OLMOS, E.; KIDDLE, G.; MOWLA, S.; KUMAR, S.; ANTONIW, J. ALVARES, M.E. FOYER, C.H. Ascorbic acid deficiency activates cell death and disease resistance responses in Arabidopsis. Plant Physiology, Lancaster, v. 139, p. 1291-1303, 2005.

RAO, M.V.; DAVIS, R.D. Ozone-induced cell death occurs via two distinct mechanisms in Arabidopsis: the role of salicylic acid. Plant Journal, Oxford, v. 17, p. 603-614, 1999.

RAO, M.V.; LEE, H.; CREELMAN, R.A.; MULLET, J.E.; DAVIS, K.R. Jasmonic acid signaling modulates ozone-induced hypersensitive cell death. The Plant Cell, Oxford, v. 12, p. 1633-1646, 2000.

RESENDE, M.L.V.; SALGADO, S.M.L.; CHAVES, Z.M. Espécies Ativas de Oxigênio na Resposta de Defesa de Plantas a Patógenos. Fitopatopatologia Brasileira, Brasília, v. 28, p. 123-130, 2003.

REYMOND, P.; GRUNBERGER, S.; PAUL, K.; MULLER, M.; FARMER, E.E. Oligogalacturonide defense signals in plants: large fragments interact with the plasma membrane in vitro. Proceedings of National Academic Science, Washington DC, v. 92 n. 10, p. 4145-4149, 1995.

ROBERTSEN, B. Elicitors of the production of lignin-like compounds in cucumber hypocotyls. Physiological and Molecular Plant Pathology, London, v. 28, p. 137-148, 1986.

ROSE, J.K.; BENNETT, A.B. Cooperative disassembly of the cellulose-xyloglucan network of plant cell walls: Parallels between cell expansion and fruit ripening. Trends Plant Science, Kidlington, v. 4, p. 176-183, 1999.

SAEMAN, J. F.; MOORE, W.E.; MITCHELL, R.L.; MILLET, M.A. Techniques for the determination of pulp constituents by quantitative paper chromatography. Technical Association for the Worldwide Pulp, Paper, and Converting Industry (TAPPI), v. 37, n. 8, p. 336-343, 1954. 
SCHIMID, M.; DAVISON, T.S.; HENZ, S.R.; PAPE, U.J.; DEMAR, M.; VINGRON, M.; SCHOLKOPF, B.; WEIGER, D.; LOHMANN, J. A gene expression map of Arabidopsis thaliana development. Nature Genetics, v. 37, p. 501-506, 2005.

SCHINEIDER, M.; SCHWEIZER, P.; MEUWLY, P.; MÉTRAUX, J. P. Systemic acquired resistance in plants. International Journal of Cytology, New York, v. 168, p. 303-304, 1996.

SHAW, S; LONG, S. Nod factor inhibition of reactive oxygen efflux in a host legume. Plant Physiology, Lancaster, v. 132, p. 2196-2204, 2003.

SHIBUYA, N.; MINAMI, E. Oligosaccharide signaling for defense responses in plants. Physiological and Molecular Plant Pathology, London, v. 59, p. 223-233, 2001.

SHIRASU, K.; NAKAJIMA, H.; RAJASEKHAR, V.K. DIXON, R.A.; LAMB, C. Salicylic acid potentiates an agonist-dependent gain control that amplifies pathogen signals in the activation of defense mechanisms. Plant Cell, Rockville, v. 9, p. 1-10, 1997.

SILIPO, A.; MOLINARO, A.; STURIALE, L.; DOW, J.W.; ERBS, G.; LANZETTA, R.; NEWMAN, M.A.; PARRILLI, M. The elicitation of plant innate immunity by lipooligosaccharide of Xanthomonas campestris. Journal of Biology and Chemistry, Baltimore, v. 280, n. 39, p. 33660-33668, 2005.

SLESAK, E.; SLESAK, M.; GABRYS, B. Effect of methyl jasmonate on hydroxamic acid content, protease activity, and bird cherry oat aphid Rhopalosiphum padi (L) probing behavior. Journal of Chemical Ecology, v. 27, n. 12, p. 2529-2543, 2001.

STICHER, L.; MAUCH-MANI, B.; MÉTRAUX, J.P. Systemic Acquired Resistance. Annual Review Phytopatology, Palo Alto-CA, v. 35, p. 235-270, 1997.

THOMPSON, J.E.; FRY, S.C. Restructuring of wall-bound xyloglucan by transglycosylation in living plant cells. Plant Journal, Oxford, v. 26, n. 1, p. 23-34, 2001.

THORDAL-CHRISTENSEN, H.; ZHANG, Z.; WEI, Y.; COLLINGE, D.B. Subcellular localization of $\mathrm{H}_{2} \mathrm{O}_{2}$ in plants. $\mathrm{H}_{2} \mathrm{O}_{2}$ accumulation in papillae and hypersensitive response during the barley-powdery mildew interaction. Plant Journal, Oxford, v. 11, p. 1187-1194, 1997.

TORRES, M.A.; DANGL, J.L.; JONES, J.D. Arabidopsis gp91phox homologues AtrbohD and AtrbohF are required for accumulation of reactive oxygen intermediates in the plant defense response. Proceedings of National Academic Science, Washington DC, v. 99, p. 517-522, 2002.

VARGAS-RECHIA, C.; REICHER, F.; SIERAKOWSKI, M.R.; HEYRAUD, A.; DRIGUEZ, $\mathrm{H}$.; LIENART, Y. Xyloglucan octasaccharide XXLGol derived from the seeds of Hymenaea courbaril acts as a signaling molecule. Plant Physiology, Lancaster, v. 116, n. 3, p. 1013-1021, 1998.

VARNER, J. E.; LIN, L. S. Plant cell wall architecture. Cell, Cambridge, v. 56, p. 231-239, 1989.

VERBERNE, M.C.; VERPOORTE, R.; BOL, J.F.; MERCADO-BLANCO, J.; LINTHORST, $\mathrm{H}, \mathrm{J} . \mathrm{M}$. Overproduction of salicylic acid in plants by bacterial transgenes enhances pathogen resistance. Nature Biotechnology, v. 18, p. 779-783, 2000. 
VORWERK, S.; SOMERVILLE, S.; SORMEVILLE, C. The role of plant cell wall polysaccharide composition in disease resistance. Trends in Plant Science, Kidlington, v. 9, n. 4, p. 203-209, 2004

WALKER-SIMMONS M.; HADWIGER, L.; RYAN, C.A. Chitosan and pectic polysaccharides both induce the accumulation of the antifungal phytoalexin pisatin in pea pods and antinutrient proteinase inhibitors in tomato leaves. Biochemical and Biophysical Research Communications, New York, v. 110, n. 1, p. 194-199, 1983.

WILDERMUTH, M. C.; DEWNEY, J.; WU, G.; AUSUBEL, F.M. Isocorismate synthase is required to synthesize salicylic acid for plant defense. Nature, London, v. 414, p. 562$565,2001$.

WILSON, R. H.; SMITH, A.C.; KACURAKOVA, M.; SAUNDERS, P. K.; WELLNWE, N.; WALDRON, K. W. The mechanical properties and molecular dybamica of plant cell wall polysaccharides studied by Fourier-transform infrared spectroscopy. Plant Physiology, Lancaster, v. 124, p. 397-405, 2000.

WHITHNEY, S. E.; GOTHARD, M. G.; MITCHELL, J. T.; GIDLEY, M. J. Roles of cellulose and xyloglucan in determining the mechanical properties of primary cell walls. Plant Physiology, Rockville, v. 121, p. 657-663, 1999.

WOLFROM, M.L.; THOMPSON, A. Reduction with sodium borohydride. Methods Carbohydrate Chemical, v. 2, p. 65-68, 1963a.

WOLFROM, M.L.; THOMPSON, A. Acetylation. Methods Carbohydrate Chemical, v. 2, p. 211-215, 1963b.

WYLLIE, A.H.; KERR, J.F.; CURRIE, A.R. Cell death: the significance of apoptosis. International Review of Cytology, v. 68, p. 251-306, 1980.

XIE, Z.; CHEN, Z. Salicylic acid induces rapid inhibition of mitochondrial electron transport and oxidative phosphorylation in tobacco cells. Plant Physiology, Rockville, v. 120, p. 217-225, 1999.

YU, B.P. Cellular defenses against damage from reactive oxygen species. Physiological Review, Rockville, v. 74, n. 1, 139-162, 1994. 
